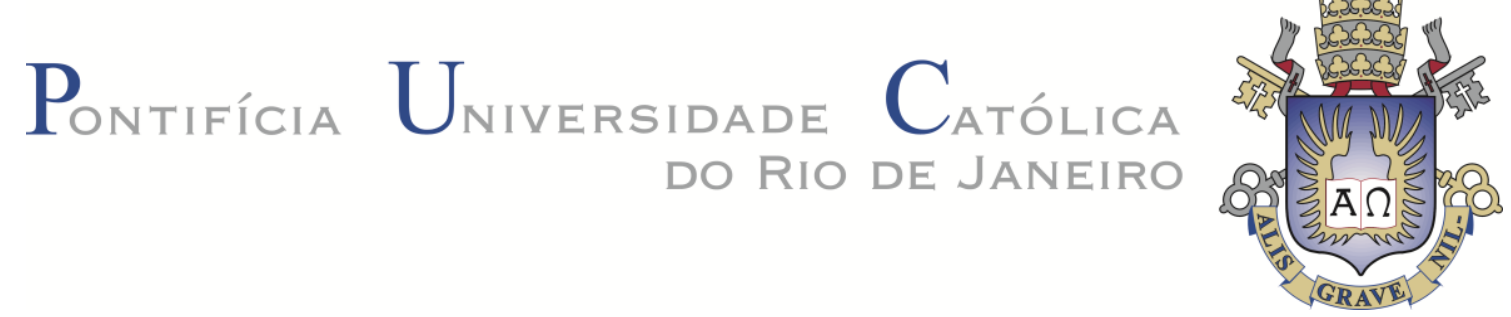

Caíque Cunha Bellato

\title{
A reportagem no Rio de Janeiro
}

\section{Dissertação de Mestrado}

Dissertação apresentada como requisito parcial para obtenção do grau de Mestre pelo Programa de Pós-graduação em Ciências Sociais do Departamento de Ciências Sociais da PUC-Rio.

Orientadora: Prof ${ }^{a}$. Maria Alice Rezende de Carvalho 


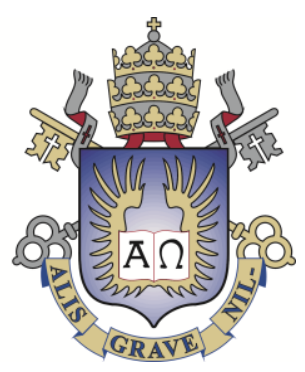

Caíque Cunha Bellato

\section{A reportagem no Rio de Janeiro}

Dissertação apresentada como requisito parcial para obtenção do grau de Mestre pelo Programa de PósGraduação em Ciências Sociais do Departamento de Ciências Sociais do Centro de Ciências Sociais da PUC-Rio. Aprovada pela Comissão Examinadora abaixo assinada.

Profa. Maria Alice Rezende de Carvalho

Orientadora

Departamento de Ciências Sociais - PUC-Rio

Profa. Maria Sarah da Silva Telles

Departamento de Ciências Sociais - PUC-Rio

Prof. Luiz Jorge Werneck Vianna Departamento de Ciências Sociais - PUC-Rio

Profa. Mônica Herz Coordenadora Setorial do Centro de Ciências Sociais - PUC-Rio

Rio de Janeiro, 25 de fevereiro de 2016 
Todos os direitos reservados. É proibida a reprodução total ou parcial do trabalho sem autorização da universidade, do autor e do orientador.

\section{Caíque Cunha Bellato}

Graduou-se em Comunicação Social (2012) e em Ciências Sociais (2013) pela Pontifícia Universidade Católica do Rio de Janeiro. Tem interesse em Sociologia e Antropologia, com ênfase nos seguintes temas: Sociologia Urbana, Teoria Social Clássica e Contemporânea e Metodologias de Pesquisas Sociais.

Ficha Catalográfica

Bellato, Caíque Cunha

A reportagem no Rio de Janeiro / Caíque Cunha Bellato; orientadora: Maria Alice Rezende de Carvalho. - 2016.

95 f. $30 \mathrm{~cm}$

Dissertação (mestrado) - Pontifícia Universidade Católica do Rio de Janeiro, Departamento de Ciências Sociais, 2016.

Inclui bibliografia

1. Ciências Sociais - Teses. 2. Sociologia. 3. Imprensa Moderna. 4. Intelectuais. 5. Rio de Janeiro. I. Carvalho, Maria Alice Rezende de. II. Pontifícia Universidade Católica do Rio de Janeiro. Departamento de Ciências Sociais. III. Título 


\section{Agradecimentos}

A minha orientadora Maria Alice Rezende de Carvalho pela inspiração e pelas conversas que deram vida ao presente trabalho. Sua atenção e dedicação em recortar e disciplinar o campo de problemas inicialmente apresentado foram fundamentais para a conclusão dessa dissertação.

Aos professores Paulo Jorge da Silva Ribeiro e Clarisse Fukelman, pela amizade e por cada uma de suas aulas.

À professora Sarah da Silva Telles, que tem acompanhado e estimulado a minha formação.

Ao professor Valter Sinder, pelos ensinamentos metodológicos e pelos comentários valiosos que me ajudaram a redefinir os rumos dessa dissertação.

Aos demais professores do Departamento de Ciências Sociais da PUC-Rio. Especialmente aos professores Luiz Werneck Viana e Marcelo Baumann Burgos pelos ensinamentos e exemplos de dedicação incansável à Sociologia. Agradeço ainda ao professor Luiz Werneck Viana pela confiança e por ter aceitado o convite para a banca de defesa dessa dissertação.

À professora Ana Paula Goulart Ribeiro, pelas críticas e orientações fundamentais por ocasião de meu exame de qualificação.

Aos funcionários do Departamento de Ciências Sociais da PUC-Rio, em especial à Ana Roxo pelo carinho e atenção.

Aos colegas do curso de mestrado que dividiram as angústias e felicidades dessa aventura acadêmica.

À CAPES e à PUC-Rio, pelas bolsas concedidas.

Agradeço, finalmente, aos meus familiares. Em especial a Camilla e Nina, minhas companheiras na vida. 


\section{Resumo}

Bellato, Caíque Cunha; Carvalho, Maria Alice Rezende de (orientadora). A reportagem no Rio de Janeiro. Rio de Janeiro, 2016. 95 p. Dissertação de Mestrado - Departamento de Ciências Sociais, Pontifícia Universidade Católica do Rio de Janeiro.

A imprensa moderna que surge concomitante à cidade moderna foi buscar no drama da novidade o elemento a diferenciar-lhe das outras formas de contar o urbano. Como empresa do ramo do entretenimento, essa nova imprensa soube explorar o interesse dos leitores acerca do distante, do excêntrico, e claro do crime, para alavancar suas vendas. Com uma nova forma narrativa e através do repórter - um novo personagem da cidade -, a imprensa moderna irá reivindicar a primazia no tratamento das questões urbanas e dos fenômenos violentos que se davam no seu espaço. $O$ presente trabalho tem como proposta a reconstrução analítica dessa perspectiva que passou a presidir as representações da cidade no início do século XX. Se hoje as imaginações construídas sobre o Rio de Janeiro estão marcadas pelo vocabulário bélico e pela ideia de uma cidade partida, no século passado a integração social da cidade foi pensada principalmente através do campo da cultura. Naquela quadra, foram os repórteres aqueles que tentaram traduzir e integrar o mundo urbano oferecendo uma imagem na qual os cariocas se reconheciam e com a qual, ainda hoje, convivemos.

\section{Palavras-chave}

Sociologia; Reportagem; Imprensa moderna; Intelectuais; Rio de Janeiro. 


\section{Abstract}

Bellato, Caíque Cunha; Carvalho, Maria Alice Rezende de (advisor). Report in Rio de Janeiro. Rio de Janeiro, 2016. 95 p. MSc. Dissertation Departamento de Ciências Sociais, Pontifícia Universidade Católica do Rio de Janeiro.

Modern press that arises at the same time to modern city sought the drama of news as the element to differentiate it from other forms of telling the city. As entertainment business company, this new press was able to explore the interest of readers about the distant, eccentric, and of course the crime, to boost their sales. With a new form of narrative and with the reporter - a new character of the city the modern press will claim primacy in dealing with urban issues and violent phenomena that occurred in its space. This paper proposes the analytical reconstruction of this perspective that came to preside over the representations of the city in the early twentieth century. If nowadays the imaginations built about the Rio de Janeiro are marked by war vocabulary and by the idea of a divided city, in the last century, the social integration of the city was thought primarily through the cultural field. That moment, reporters were those who tried to translate and integrate the urban world offering an image in which the locals recognized themselves and which, even today, we deal with it.

\section{Keywords}

Sociology; Report; Modern press; Intellectuals; Rio de Janeiro. 


\section{Sumário}

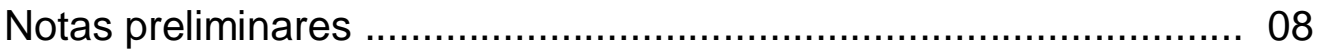

1. Introdução

1.1. Profissão de risco

2. A cidade e seus olhares

2.1. Allegro ma non troppo: o sonho do progresso e o imperativo da ordem

2.2. Reportagem: um modo de contar a cidade

2.4. Da redação às ruas: em busca da alma da cidade

3. Considerações finais

3.1. A civilização do espetáculo 82

4. Referências bibliográficas 


\section{Notas preliminares}

A primeira consideração sobre o presente texto é uma explicação acerca do seu título vago e genérico. A Reportagem no Rio de Janeiro. Pretendo - daqui em diante - apresentar um panorama de discussões sobre a prática da reportagem, em especial a reportagem policial, no Rio de Janeiro sem, necessariamente, aprofundar a análise em questões específicas. À maneira dos ensaístas, o esforço desprendido será em compreender o contorno do objeto, em desenhar um mapa no qual o "problema" como um todo possa ser melhor visualizado, colocando de lado os detalhes entrevistos no percurso para que sejam analisados em outro momento. Se me detenho por mais tempo em uma ou outra figura histórica ou em um veículo de imprensa específico, o intuito não é outro senão destacar características gerais do meu objeto de estudo. De todo modo é preciso, já aqui, deixar claro com que ideia de reportagem estamos trabalhando. Com o aparecimento da cidade moderna, surge um novo modo de ver e contar a cidade. A imprensa moderna, que ensaia seus primeiros passos nesse mesmo contexto histórico, foi o local onde esse novo olhar, essa nova perspectiva, se desenvolveu. A conexão profunda que então se estabelece entre cidade e imprensa pode ser percebida na atuação de um novo personagem que se movimenta das altas rodas burguesas às áreas de degradação urbana. A reportagem e seu narrador e ator principal - o repórter passaram, desde o final do século XIX, a presidir as narrativas sobre a cidade do Rio de Janeiro e sobre os fenômenos violentos que se dão no seu espaço. Sobre esse novo personagem urbano e sobre sua maneira peculiar de contar a cidade que o presente trabalho irá tratar.

Uma segunda consideração, que não pode deixar de ser feita, é acerca dos dois momentos históricos contemplados nessa análise. Em um esforço de reconstrução analítica, pretendo aproximar as questões presentes no "fazer reportagem" dos primeiros repórteres daquelas presentes atualmente nessa categoria profissional. Muitos dilemas permanecem, outros tantos se atualizam. Naquele período histórico que se convencionou chamar de belle époque carioca, o repórter profissional se estabelece como um ator de destaque na construção de específicas representações da violência urbana. Para além das aproximações entre 
esses dois momentos [início dos séculos $\mathrm{XX}$ e XXI] pelo tipo de intervenção urbanística que estamos assistindo, penso que ao reconstruir analiticamente a perspectiva que passou a presidir as narrativas sobre a cidade no início do século passado, podemos jogar luz sobre dilemas atuais acerca da prática de reportagem e - o que considero ainda mais valioso - refletir sobre as imagens que mobilizamos para falar do Rio de Janeiro.

Por último, é preciso esclarecer o motivo da escolha pelas reportagens policiais como objeto de reflexão. É notória a importância que a seção de crimes teve, e na verdade ainda tem, na imprensa moderna. O crime é a notícia mais irresistível e pitoresca. A nova imprensa, que se diferencia daquela do contexto imperial como um negócio ligado principalmente ao ramo do entretenimento, irá desenvolver uma linguagem atenta a tudo aquilo que possa "prender" o leitor de um jornal pago. As chamadas "páginas policiais" terão nesse contexto um lugar de destaque. No Rio de Janeiro, os grandes crimes que mobilizaram a atenção popular ao longo de décadas e renderam matérias nos seus principais jornais deram lugar ao crime organizado, ao narcotráfico, e aos conflitos urbanos. O aumento da criminalidade violenta, nos últimos anos, trouxe para a agenda da cidade a questão da segurança pública. Outrora, assunto restrito a poucos atores, agora a temática da segurança é uma das principais demandas de discussão dos cariocas. A imprensa não passou incólume por tais mudanças na ambiência da cidade. Evidente que hoje a crítica social e o tratamento intelectual da cidade se dão em um território discursivo muito mais povoado por diferentes saberes, diferentes vozes. No entanto, como seus pares do início do século passado, ainda hoje, são os repórteres os atores que buscam nas ruas do Rio de Janeiro a inspiração para traduzir os dramas, conflitos e mudanças por que passam os citadinos. 


\title{
1.
}

\section{Introdução}

\section{1.}

Profissão de risco

\begin{abstract}
A cidade civilizou-se e modernizou-se expulsando para os morros e periferia seus cidadãos de segunda classe. O resultado dessa política foi uma cidade partida. Juntá-la talvez seja tarefa para o próximo século, mas será preciso começar já - até porque a política de exclusão foi um desastre.
\end{abstract}

Zuenir Ventura, Cidade Partida.

As décadas finais do século $\mathrm{XX}$ podem ser vistas como cruciais para a percepção das mudanças ocorridas no país e na cidade do Rio de Janeiro. O final do período ditatorial foi não somente uma ruptura com o padrão institucional vigente, mas também um momento de alteração profunda nos modos de se pensar a realidade social brasileira. Luiz Werneck Vianna afirma que o processo de democratização que pôs fim ao regime militar e, em seguida, as vitoriosas demandas pela convocação de uma assembleia constituinte deixaram evidente o deslocamento que a sociedade vinha operando no seu sistema de orientação ${ }^{1}$. Quando a luta contra a ditadura militar deixa de ser a questão hegemônica no debate nacional, abre-se espaço para novos problemas e reflexões inspirados pela democratização no país. Mudam, a partir de então, as perspectivas pelas quais a cidade é pensada. A Carta de 88, não por acaso chamada de Carta Cidadã, marca essa valoração da sociedade civil, esse desejo pela descentralização e pela proeminência do poder local sobre o central. Ainda segundo Werneck Vianna, nesse período, a mutação que diz respeito às ciências sociais guarda uma estreita relação com os processos de mudanças macroestruturais nos padrões de sociabilidade pelo qual o país passava. Segundo nossa hipótese, na imprensa esse processo de mudanças também foi percebido, embora tenha resultado em

\footnotetext{
${ }^{1}$ WERNECK VIANA, Luiz. A propósito de uma introdução. In. Redemocratização e mudança social no Brasil. Org. Maria Celina D’Araújo. Rio de Janeiro: FGV, 2014. pp. 11-17.
} 
perspectiva que - ao contrário do que se deu nas ciências sociais, na qual o caráter normalizador foi abrindo espaço para uma postura mais compreensiva - tem favorecido uma compreensão de cidade que aponta para o controle como única forma de superar a evidente crise de sociabilidade. $\mathrm{O}$ discurso que a imprensa tem apresentado acerca do urbano e dos fenômenos violentos que se dão no seu espaço, desde meados da década de 1980, tem contribuído para a reificação da ideia de territorialização e de guerra urbana. Ainda que não reine mais sozinha na arena discursiva, tal compreensão da cidade advinda da imprensa se reflete não somente nas políticas públicas apresentadas pelo Estado, marcadas pela ideia e pelo léxico da guerra, como também no próprio modo de viver dos citadinos.

Werneck Vianna traça, com precisão e em poucas páginas, a mudança pela qual passou as ciências sociais no Brasil nos seus quase noventa anos de vida institucional ${ }^{2}$. Segundo o autor, em outros contextos nacionais, o momento de institucionalização da disciplina consistiu em uma resposta aos graves problemas sociais derivados do processo de industrialização, da massiva urbanização e do derruimento da sociedade tradicional, de suas instituições e valores. Casos paradigmáticos seriam os da Inglaterra, França e Estados Unidos - esse último deixando ainda mais evidente a responsividade da disciplina com a atuação da Escola de Chicago, profundamente envolvida em um esforço de normalização da vida social. No Brasil, ao contrário, a procura de interação reflexiva com a sociedade não irá coincidir com os propósitos iniciais da institucionalização da disciplina, encapsulada nos seus primeiros anos no ambiente acadêmico. Somente após a queda do Estado Novo, sob a influência da obra de Karl Mannheim acerca do papel de uma intelligentzia orientada para agir sobre a esfera pública - a disciplina começa a se abrir aos problemas da sua sociedade. A partir do diagnóstico de que estaria em andamento um processo que nos levaria de uma ordem de estilo patrimonial a uma ordem competitiva, a sociologia centrou seu foco na questão do Estado e no processo histórico de sua formação. Com um viés macroestrutural, a disciplina se voltou para a denúncia da condição de heteronomia a que estava submetida a sociedade. Segundo Werneck, o regime militar interrompe esse processo de encontro da disciplina com os dilemas da sua sociedade. O novo regime pôs, novamente, em evidência o que havia de

\footnotetext{
${ }^{2}$ WERNECK VIANA, Luiz. A propósito de uma introdução. Op. cit.
} 
constitutivamente autoritário na história da nossa formação. A compreensão desse contexto reclamaria o recurso à sociologia histórica comparada e, uma vez mais, à perspectiva macroestrutural. Ainda segundo o autor, somente com a democratização do país, consolidada com a nova constituição, as ciências sociais giram o eixo da sua orientação e se encontram com a agenda perdida com o truncamento da ordem democrática em 1964, "embora em outro contexto, quer na história do país, quer no estado da arte da disciplina".

A tradição analítico-interpretativa brasileira, centrada na questão do Estado estaria sendo substituída pela de cidade - e, com ela, a da cidadania e seus personagens. Maria Alice Rezende de Carvalho propôs, na década de 1990, o argumento de que "a cidade substituía o Estado como centro gravitacional da vida coletiva e, mais importante, tornava-se um objeto de investigação regulado por uma agência específica, a Universidade, e por um código disciplinar." (1995a:262). No que tange a temática da violência urbana, Maria Alice marca o distanciamento atual da disciplina quanto à produção hegemônica nos anos 1970 afirmando que os especialistas tem procurado dotar esse tema de alguma autonomia analítica frente aos indicadores macroeconômicos. As análises recentes têm questionado o tipo de abordagem que teria marcado grande parte da literatura produzida sobre a violência urbana brasileira e que privilegiara a criminalidade em suas conexões com o padrão autoritário de modernização do país ${ }^{3}$ (Carvalho, 1995b). Essa recente literatura sobre violência urbana estaria, conforme o argumento da autora, deslocando o modelo da causação social do crime e enfatizando, alternativamente, ora o contexto institucional, ora o cultural em que se verificam oscilações significativas no índice de delitos violentos. Essas análises "contextualistas" da violência dedicam menor atenção ao macroambiente político, atendo-se, predominantemente, à microfísica da atividade criminosa e à sua capacidade de produzir incentivos à delinquência. Dessa forma, a discussão sobre a violência urbana, dentro das ciências sociais, tem abandonado a preocupação

\footnotetext{
${ }^{3}$ Segundo essas análises, a escalada da pobreza e os níveis de desigualdade que resultaram do descaso do Estado em implementar políticas distributivas mais progressivas ao longo do período de crescimento econômico seriam os fatores responsáveis pela ampliação das taxas de conflito no Brasil. [...] Neles, entre outras características, chama a atenção a desimportância atribuída às especificidades de cada cidade e a associação imediata entre as variáveis macroeconômicas e o padrão de conflito social experimentado no mundo urbano brasileiro. In. CARVALHO, Maria Alice Rezende de. Cidade escassa e violência urbana. Série Estudos, luperj: Rio de Janeiro, n 91 / agosto de 1995b.
} 
exclusiva com o crime e apontado para questões mais amplas, tais como a da sociabilidade e seus limites.

Assim a cidade deixa de ter o status originalmente concedido pela sociologia - o de uma variável independente, indicativa das mudanças estruturais observadas durante o nosso processo de modernização - e abre-se a outros tipos de pesquisas "sobre a intensa fragmentação cognitiva e valorativa dos seus habitantes e sobre os canais de circulação entre os diferentes "mundos" que ali interagem"4. Segundo Maria Alice, pode-se perceber nesse momento um deslocamento do topos sociológico, excessivamente normalizador em muitos momentos, em favor de uma perspectiva antropológica de análise, mais compreensiva do que explicativa. Conforme a autora, a sociologia, como disciplina, havia inventado a cidade e sua uniformidade social, caberia, então, à antropologia pesquisar as bases culturais das diferenças e os canais de circulação entre mundos tão diversos presentes nas grandes metrópoles (Carvalho, 1995a:265).

Se no ambiente acadêmico emerge uma perspectiva mais compreensiva acerca do urbano, na imprensa o caminho parece ter sido o exato oposto. Se nos primórdios da reportagem, figuras como João do Rio e Irineu Marinho puderam estabelecer uma espécie de língua franca da cidade ao enxergarem vias de integração do espaço urbano, principalmente através da cultura, nos anos 1980 o agravamento da crise de sociabilidade urbana parece ter desnorteado os repórteres da cidade. Aqueles que outrora foram tradutores da experiência, também traumática, de urbanização e modernização do Rio de Janeiro, hoje parecem não mais estar à altura do desafio presente de traduzir ou de criar um léxico que favoreça a integração social do espaço urbano. O olhar que os repórteres hoje lançam sobre o tema da violência urbana tem imposto a metáfora da guerra como o único caminho de interpretação do momento atual da cidade. A perspectiva que marcou o início da imprensa popular e moderna na cidade e que teve como um dos maiores representantes o repórter João do Rio, qual seja a de um olhar que tem como posto de observação as ruas e que necessita da movimentação pela cidade, da arte de flanar, para captar a sociabilidade advinda do ambiente urbano,

${ }^{4}$ CARVALHO, Maria Alice Rezende de. Cidade escassa e violência urbana. Op. cit., p.4. 
vai dando lugar a uma perspectiva que além de apresentar certa cegueira antropológica - pois não enxerga na alteridade senão uma possibilidade de intervenção -, tem uma compreensão da crise de sociabilidade que reforça formulações como a de que vivemos em uma "cidade partida".

Com a expansão do tráfico de drogas e armas, a criminalidade cresceu de maneira exponencial no Rio de Janeiro e no país a partir da década de 1980. De tal forma, que o noticiário sobre a violência transbordou dos "seus tradicionais redutos nas editorias e jornais especializados em crimes e [ganhou] destaque, de maneira generalizada, em todos os meios de comunicação" (Rondelli, 2000:144). Sem dúvida, nas últimas décadas, o fenômeno da violência urbana se tornou mais complexo e os órgãos de imprensa e seus profissionais também mudaram em muitos aspectos. No livro "50 anos de crimes - Reportagens policiais que marcaram o jornalismo brasileiro", o organizador da coletânea, Fernando Molica, mostra o agravamento e a disseminação da violência na sociedade brasileira e a mudança de perspectiva dos jornais para abordar o tema. É possível acompanhar nessas narrativas a transição não só do tempo, mas do olhar que os repórteres adotam para contar a cidade e suas mazelas.

O crime dos anos 1950/60 tendia à individualização, ou pelo menos assim era percebido pelos repórteres. Segundo Molica, era como se cada um daqueles episódios (ações criminosas ou violentas) fosse considerado um desvio, uma anomalia que poderia ser isolada. Ao repórter cabia identificar e caracterizar a fonte desse distúrbio momentâneo. Figuras como Mineirinho e Cara de Cavalo eram perseguidas por repórteres que sonhavam em transformar-lhes em personagens de suas histórias. As reportagens desse período revelam observadores ainda inseridos no ambiente dos acontecimentos, repórteres conhecedores da cidade, de sua dinâmica, que para encontrarem seus personagens ainda se dirigiam às ruas. Algumas vezes, o faro dos repórteres, seu senso de oportunidade, era mais eficaz que o da própria polícia. A matéria publicada no dia 2 de maio de 1962 no jornal O Dia sobre a morte do bandido Mineirinho, executado pela polícia após um longo período de perseguição, revela que o cadáver foi descoberto pela reportagem de O Dia e A Notícia e os policiais foram conduzidos ao local onde estava o corpo em um carro de reportagem. 
Reconhecendo o cadáver como sendo de "Mineirinho", o repórter José Bouças e o fotógrafo Hino Patrício, de O Dia e A Notícia, rumaram para a Delegacia do $17^{\circ}$ Distrito Policial, cujo titular, o delegado Hermes Machado, acompanhado do detetive Armindo, foi conduzido ao local na viatura desta empresa, constatando que, de fato, aquele era o corpo de "Mineirinho". (O Dia 02/05/1962) ${ }^{5}$.

Em outubro de 1961, Octávio Ribeiro, o famoso Pena Branca ${ }^{6}$ um dos mais notórios repórteres de polícia do país, conseguiu uma entrevista exclusiva para o jornal Última Hora com o assaltante Mineirinho, então foragido. Para chegar até o bandido, o repórter improvisou e usou métodos que fariam seu nome conhecido no meio jornalístico.

Durante vários dias, o repórter Octávio Ribeiro vasculhou morros da Guanabara e do Estado do Rio. Dormiu em favelas, em barracos de madeira, chão de terra e teto de lata. Conversou com a gente desse mundo diferente da vida do asfalto. Fez amizades com malandros e assaltantes. Pagou pinga nas biroscas onde alguém pudesse fornecer uma pista para a localização de "Mineirinho" - o homem caçado, vivo ou morto, pela Polícia de dois estados. E só voltou à redação quando conseguiu furar o cerco policial, trazendo fotos e as declarações de "Mineirinho", em sensacional entrevista exclusiva". (Última Hora, 11/10/1961)

As representações e as imagens de favela, ainda hoje, não conseguiram se desvencilhar do seu "mito de origem". Lícia Valladares (2000) ao reconstituir a forma pela qual a categoria favela foi sendo substantivada ao longo das primeiras décadas do século XX, mostra como ela foi e é empregada como antônimo de cidade. A gente desse mundo diferente do asfalto, como na reportagem de Última Hora, vive em territórios exóticos, apartados da cidade, com uma sociabilidade avessa à ordem urbana e social estabelecida. Segundo Valladares, essa imagem de um mundo diferente, de uma cidadela da miséria, irá plasmar um arquétipo de favela, lançando as bases necessárias para a sua transformação em problema (2000:36). As imagens da fratura social e de uma cidade partida seriam uma produção intelectual que constrói a representação da favela como "território da violência, como lugar de todas as ilegalidades, como bolsão da pobreza e da exclusão social" (2000:20). A crítica da autora não se dirige prioritariamente a

\footnotetext{
${ }^{5}$ Essa e demais matérias apresentadas nesse capítulo foram recuperadas por Fernando Molica no livro "50 anos de crimes - Reportagens policiais que marcaram o jornalismo brasileiro".

${ }^{6}$ Octávio Ribeiro, o "Pena Branca", de tão conhecido no meio jornalístico, chegou a inspirar a criação do personagem Waldomiro Pena, repórter interpretado por Hugo Carvana no seriado Plantão de Polícia, da Rede Globo.
} 
atividade da imprensa, em sua mira estão as formas pelas quais a favela se constituiu como problema social e como problema sociológico.

Segundo a autora, um conjunto de pressuposições marca a produção sociológica recente sobre o tema. Sob uma figuração homogeneizadora da favela, perde-se de vista uma notável diversidade social e espacial presente nesse universo, bem como o dinamismo social e econômico que vem marcando essas realidades. Vista sob uma categoria única, em que pese as evidências de uma realidade plural e multifacetada, a favela segue desconhecida, bem como a pobreza urbana e a própria cidade. Conforme sugere a autora, deve-se buscar perspectivas que permitam dissolver a dualidade pressuposta "favela-cidade" para se colocar em evidência questões pertinentes à vida urbana, não exclusivas às favelas, mas que podem ganhar novos critérios de inteligibilidade a partir da sua problematização.

Conforme sugere Maria Alice Rezende de Carvalho, a cidade, forma material da modernidade, talvez necessite ser inquirida por seus espaços mais instáveis, mais precários, a fim de que se problematize a gênese da organização de um modo de vida, de um ethos urbano (2014). Como mostra Licia Valladares (2000), os anos de 1990 testemunharam um renovado interesse da academia pelo tema favela. As pesquisas multiplicaram-se e um número crescente de alunos de pós-graduação passou a se interessar pelo assunto, instituições governamentais e não governamentais ganharam igualmente peso na demanda de pesquisas e o Programa Favela-Bairro lançado pela prefeitura do Rio de Janeiro em 1993 acentuou ainda mais a produção desses estudos. No entanto, como afirma a autora, essa produção foi marcada por pressupostos que limitaram os trabalhos a uma perspectiva que enxergou nas favelas apenas o oposto do território formal da cidade. A imprensa que poderia ser uma fonte produtora de integração social, com seus agentes - os repórteres - movimentando-se por todo o território urbano, assim como a academia, mesmo quando está dentro das favelas mantém um olhar que não permite enxergar na favela senão o território de carências, o negativo da cidade.

No artigo Direto do front: notas sobre reportagem e narcotráfico no Rio de Janeiro, Carlos Nobre conta como repórteres da editoria de cidade dos jornais 
cariocas passaram a cobrir em morros e favelas do estado as investidas policiais de combate ao narcotráfico. $\mathrm{O}$ autor, repórter experiente com passagem pelos grandes jornais da cidade, conta que o surgimento do narcotráfico, na década de 1980, surpreendeu a reportagem policial carioca, preparada para cobrir casos de homicídios, roubos, furtos, assaltos, julgamentos de criminosos e, principalmente, crimes passionais envolvendo algumas celebridades. Quando a polícia começou a fazer as chamadas "operações" de repressão ao tráfico no próprio reduto dos chamados "donos do morro", os repórteres - no rastro dessa nova modalidade de atuação policial - passaram a cobrir essas ações direto das zonas conflituosas, segundo o autor, "para levar ao leitor as informações - e até as emoções - mais quentes da guerra entre traficantes e policiais”. Em 1981, uma investida policial para prender bandidos que se escondiam em um conjunto habitacional na Ilha do Governador se transformou em um grande tiroteio e marcou o início da atuação da organização criminosa, então chamada Falange Vermelha, na cidade. A reportagem de Jorge Martins, em O Globo, conta como foi esse conflito.

"O mais longo tiroteio da história da polícia carioca durou dez horas - das 22 horas de anteontem às 8 de ontem - e dele participaram cerca de 300 homens da Polícia Civil e outros 100 da Polícia Militar, contra um homem, o assaltante de bancos e fugitivo da Ilha Grande José Jorge Saldanha, o Zé Bigode. $\mathrm{O}$ assaltante resistiu a milhares de tiros de escopeta, metralhadoras, revólveres, dezenas de bombas de gás lacrimogêneo, três granadas Odete, considerada uma das mais potentes entre os armamentos modernos". (O Globo de 05/04/1981)

O arsenal e a operação das Polícias Civil e Militar descritos pelo repórter de O Globo evidenciam que a crise de violência urbana chegava a um novo patamar. Segundo Nobre, "os repórteres se viram obrigados a lançar um "novo olhar" para a realidade dos morros cariocas. Acabara, dali por diante, certo romantismo na cobertura policial, em que agentes da lei e vilões eram de certo modo glamourizados pela imprensa". Essa tolerância para com o que havia de desviante não era exclusividade dos repórteres policiais da cidade. Segundo Maria Alice Rezende de Carvalho (1995b), durante o regime militar, a sociedade, em geral, parece ter experimentado um certo afastamento do quadro normativo vigente, isto é, uma recusa - latente ou manifesta - às instituições do autoritarismo. Desconhecendo, dessa forma, restrições muito severas às formas selvagens ou mesmo ilegais que o "inconformismo dos marginalizados" pudesse assumir. A compreensão do agravamento da crise de sociabilidade nos anos 1980 não pôde 
mais se basear no imaginário social das décadas de 1960 e 1970 que valorizava atitudes que desafiassem a ordem ditatorial, muitas vezes idealizando o personagem criminoso. Os novos tempos demandavam outras categorias discursivas.

Não é alheio o fato de que nos anos 1980, quando a cidade começa a ser foco das atenções da imprensa pela emergência do crime organizado, desordem urbana, e violência, um jornalista como João do Rio, que subia morros, visitava manicômios, presídios, opiários e outros ambientes, ditos por ele mesmo, de degradação humana, tivesse audiência e projetasse sua obra. Após meio século esquecido, desde 1921 quando morreu, João do Rio começa a ser recuperado na década de $1980^{7}$. A fortuna crítica do autor, hoje muito mais ligada à sociologia e à antropologia do que à crítica literária, tem muito a ver com a necessidade de compreensão da cidade. A reportagem praticada por João do Rio pôde nos contar algo acerca da trajetória de uma cidade que então precisava ser melhor entendida, seus pressupostos se não estão em voga hoje com certeza não é pelo fato de termos alcançado o objetivo de compreender, de captar a alma da cidade.

Quase um século distantes de João do Rio e daquela imprensa popular e moderna que nascia, não podemos esperar que a atual empresa jornalística voltada para atender as expectativas do seu público leitor, cada vez mais exclusivamente ligadas ao entretenimento - mantenha a mesma postura dos seus anos iniciais. A experiência de Carlos Nobre como repórter na cidade permite que, sem maiores pudores, o autor evidencie os atuais critérios jornalísticos que definem a presença de uma equipe de reportagem em um local onde, por exemplo, está sendo feita uma intervenção policial. Segundo o autor, os jornais cujos leitores são de classe A/B, em geral, tendem a acompanhar operações policiais quando se trata de fato previamente confirmado com as seguintes potencialidades de "notícia": "grande número de policiais envolvidos na operação, a possibilidade de serem obtidas imagens chocantes, potencial de conflito com traficantes, a possibilidade do conflito se estender aos bairros de classe média

\footnotetext{
${ }^{7}$ Segundo Julia O'Donnel, da data de sua morte até 1971 - quando foi lançada uma antologia da sua obra - o nome de João do Rio deu título a apenas três capítulos de livros dedicados à literatura brasileira. Na década de 1980, Antônio Cândido com o artigo "Radicais de ocasião" dá início a uma fase de renovado interesse pelo cronista que terá nos anos 2000 seu ápice, com a reedição de seus principais livros e alguns títulos dedicados a sua vida. (O'Donnel, 2007:26).
} 
vizinhos às comunidades, morte de inocentes por balas perdidas, denúncia de torturas e mortes de moradores" (Nobre, 2005). Alguns destes critérios, segundo Nobre, também balizam a cobertura dos jornais cujos leitores são das classes $\mathrm{C} / \mathrm{D} / \mathrm{E}$ - os chamados jornais populares. Estes, no entanto, como baseiam sua cobertura praticamente no que acontece na cidade - e como seus leitores são bastante influenciados pela ação da criminalidade - tendem a cobrir mais os fatos policiais que os jornais de classe média. A busca pelo fato extraordinário que servirá à produção da notícia deixará em segundo plano a tentativa de compreensão do fenômeno da violência urbana. Sintoma de um tempo que privilegia a diversão em lugar da reflexão, mesmo quando o assunto em pauta diz respeito à vida de cada um.

Generalizações devem sempre ser evitadas se quisermos uma visão que nos ajude a entender a realidade social em que nos encontramos imersos. Não se pode negar que repórteres também têm tentado uma cobertura mais compreensiva do momento atual. Durante a década de 1990, os repórteres da cidade, ainda que limitados na sua perspectiva pelos "óculos especiais" 8 que os jornalistas utilizam, buscaram - assim como os pesquisadores acadêmicos - entrar nesse mundo diferente do asfalto a fim de encontrar elementos para compreensão do drama vivenciado. Em 1992, após o assassinato da dona-de-casa Diva Dias de Souza, de 50 anos - que foi torturada e morta a tiros por traficantes da favela do Jacarezinho, onde morava -, o Jornal do Brasil pediu ao repórter Renato Garcia uma série de reportagens que seriam o retrato do narcotráfico no Rio de Janeiro. Durante 30 dias Renato trabalhou na produção dessas matérias. Passou a visitar a favela do Jacarezinho, conversou com moradores, comerciantes, lideranças comunitárias e policiais até o momento em que o tráfico local permitiu. Com a impossibilidade de voltar ao Jacarezinho, o repórter buscou outros redutos do narcotráfico. Entrou em Bangu I e conversou com a cúpula do Comando Vermelho. Em postura etnográfica, documentou a dinâmica do varejo de drogas em um morro do Andaraí. A série de reportagens "República do Pó" de Renato Garcia, Antônio José Mendes e Hélio Muniz, recebeu o prêmio Esso regional Sudeste daquele ano.

\footnotetext{
${ }^{8}$ A expressão é de Pierre Bourdieu. Segundo o autor, jornalistas usam "óculos especiais" a partir dos quais veem certas coisas e não outras. Essa forma particular de observação é influenciada pelo habitus e pela estrutura do campo jornalístico (1997:25). Adiante [considerações finais] retomaremos esse argumento.
} 
Se os anos 80/90 marcam a compreensão de cidade dos repórteres como um território em guerra, a virada do século erguerá ainda mais alto as fronteiras que dividem a cidade no imaginário desses profissionais. Em junho de 2002, o repórter Tim Lopes foi capturado por um grupo de traficantes enquanto produzia uma reportagem sobre exploração sexual de menores em uma favela do Complexo do Alemão, Zona Norte do Rio de Janeiro. Tim Lopes teria sido descoberto com uma câmera escondida. Depois de torturado pelos bandidos, o repórter foi esquartejado, queimado e enterrado. Seus restos mortais foram encontrados em um cemitério clandestino, no alto do morro, com outras dezenas de ossadas. Após mais de três meses de buscas intensas, Elias Maluco - o chefe do bando, que teria matado pessoalmente o repórter - foi preso. Esse assassinato bárbaro irá redefinir a prática de reportagem policial na cidade do Rio de Janeiro.

Desde a morte de Tim Lopes, os repórteres que cobrem criminalidade vêm repensando suas práticas. Os costumes de acompanhar ações policiais e infiltrarse em favelas, por exemplo, estão sendo abandonados pela maioria dos repórteres dessa área ${ }^{9}$. Ao buscar métodos de trabalho mais seguros, esses profissionais chegaram a uma situação paradoxal. De fato, ainda são repórteres - se utilizam da reportagem para contar suas histórias, estão ligados a uma empresa jornalística, buscam no drama da novidade o elemento que irá conquistar seu leitor -, porém, já não cumprem a premissa fundamental dessa profissão: testemunhar de perto os eventos que serão narrados. Durante o seminário "Jornalismo de Risco no Brasil: Tim Lopes, 10 anos depois" realizado nos dias 31 de maio e $1^{\circ}$ de junho de 2012, na ESPM (Escola Superior de Propaganda e Marketing), no Centro do Rio de

\footnotetext{
${ }^{9} \mathrm{O}$ caso de Tim Lopes foi emblemático, mas não foi o único desde então. Em agosto de 2005, a repórter da TV Bandeirantes, Nadja Haddad foi atingida por um projétil de submetralhadora, quando chegava para fazer a cobertura de um tiroteio no morro Santa Marta, em Botafogo, Zona Sul do Rio de Janeiro. A bala feriu a jornalista dentro do carro de reportagem, que não era blindado. Nadja estava sem colete protetor. Seis anos após o assassinato de Tim Lopes e três anos depois de uma tentativa de sequestro sofrida pela repórter Vera Araújo após a publicação de matéria denunciando pela primeira vez o esquema criminoso das milícias, o jornal O Dia mandou para um reduto miliciano um fotógrafo, uma repórter e um motorista. A equipe foi sequestrada e torturada durante sete horas e liberada sob a orientação de não publicar a reportagem que estavam produzindo no local. Em 2011, o cinegrafista Gelson Domingos, da TV Bandeirantes, morreu após ser baleado no peito enquanto cobria uma operação policial na favela de Antares, em Santa Cruz, na zona oeste do Rio. Ele vestia um colete à prova de balas, que não resistiu ao tiro de fuzil que atravessou a proteção.
} 
Janeiro, Marcelo Moreira, então presidente da ABRAJI ${ }^{10}$ (Associação Brasileira de Jornalismo Investigativo), disse que a morte de Tim Lopes foi um marco no jornalismo investigativo no Brasil. Matérias que demandam infiltração do repórter em ambientes hostis fariam parte, agora, de um período romântico do jornalismo policial. A tendência atual - diz Marcelo Moreira - seria deixar de enfatizar o papel do jornalista como testemunha ocular dos fatos e passar a valorizar a capacidade do repórter de contar uma história a partir de relatos de terceiros. Em entrevista a Clarinha Glock (2006), João Antônio Barros, então chefe de reportagem de O Dia, diz que cada vez mais se cobre por telefone e menos pela rua. "Em O Dia está proibido fazer matéria em favela do tipo "viver um tempo ali para denunciar" ou sobre as leis do tráfico. Agora se faz só o que chega ao asfalto".

Nessa lógica de territorialização, que separa a cidade formal da cidade informal, as investidas dos repórteres para cobrirem os fatos de violência urbana ficam detidas a uma geografia dual da cidade. Sem acessarem o local dos acontecimentos, esses novos repórteres narram suas histórias sem de fato presenciá-las. O paradigma fundamental da reportagem, de ser um relato de um sujeito que viu ou presenciou os fatos, começa a ser relativizado. E não apenas o testemunho do repórter, mas também os de moradores de favelas ficam de fora da cobertura que a imprensa tem feito sobre o tema. A ausência do ponto de vista dos moradores dessas regiões, o contato restrito com essa importante fonte na matéria sobre criminalidade urbana, tem marcado as reportagens que tratam do assunto. Atualmente, a abordagem da mídia sobre favelas não reflete a pluralidade de experiências vividas pelos moradores dessas comunidades ${ }^{11}$. No mencionado

\footnotetext{
${ }^{10}$ A Associação Brasileira de Jornalismo Investigativo, a ABRAJl, foi criada em 2002 por um grupo de jornalistas interessados em trocar experiências, informações e dicas sobre reportagem, principalmente sobre reportagens investigativas. Mantida pelos próprios associados, a ABRAJI tem o objetivo de organizar congressos, seminários e oficinas para promover o aperfeiçoamento profissional dos jornalistas interessados no tema "investigação".

${ }^{11}$ Em 2001, a ONG Viva Rio criou o portal Viva Favela, um site colaborativo em que é possível ler e publicar conteúdos sobre temas relacionados às favelas e às periferias urbanas. No site, qualquer pessoa cadastrada pode se tornar um colaborador e publicar textos, imagens, áudios e vídeos, ou ainda divulgar eventos e serviços de sua comunidade na rede. Além do site em si, o Viva Favela oferece um programa de formação de correspondentes comunitários através de oficinas de capacitação em diferentes suportes e ferramentas de mídia. A ideia é ir além da imagem superficial e muito ligada à violência, oferecida, de modo geral, pela mídia tradicional, e
} 
seminário "Jornalismo de Risco no Brasil: Tim Lopes, 10 anos depois", a repórter do jornal O Globo, Vera Araújo ${ }^{12}$ afirmou ser importante driblar as dificuldades do cotidiano para buscar uma cobertura de favela mais diversificada e independente do discurso policial. A repórter contou qual tem sido a via alternativa para chegar até os moradores, fonte fundamental para essas reportagens: "uma das técnicas que estamos utilizando é tirar a pessoa da favela e manter o anonimato" 13 . Ou seja, do território apartado da cidade só chega o depoimento de poucos moradores - ainda assim sob o véu do anonimato. O drama vivido, a ambiência local, as formas de interação, tudo isso escapa ao repórter que já não está lá para observar essa parte da cidade. Para o jornalista Caco Barcellos, a mídia não está cobrindo bem esse universo. "Os jornalistas acreditam cegamente, na maior parte das vezes, nas informações da polícia, que nem sempre têm qualidade, apuração criteriosa" (Paiva e Ramos, 2007:85). Barcellos afirma que é impossível cobrir direito um universo se você não o frequenta. "Não bastam a internet, as fontes de pesquisa. Estas são fundamentais, mas são acessórios. O jornalista tem de estar perto das pessoas".

É significativo que o assassinato de Tim Lopes ao invés de servir para chamar a atenção para a situação alarmante pela qual passam os moradores das áreas submetidas a mandões locais tenha somente evidenciado a existência das fronteiras da cidade, sobrecarregando ainda mais a estigmatização desses locais. A sensação de insegurança dos repórteres da cidade, intensificada pela morte de Tim Lopes, faz com que muitos profissionais - ainda hoje - só entrem nas favelas quando acompanhados pela polícia. Este receio também tem contribuído para que a cobertura dos espaços populares seja dominada pelas ocorrências policiais ${ }^{14}$, o

influenciar um olhar mais atento e menos monotemático sobre as comunidades por parte de veículos da grande mídia.

${ }^{12}$ A repórter Vera Araújo passou um ano afastada do jornal por conta de ameaças depois de assinar, em março de 2005, uma reportagem sobre as milícias armadas - formadas principalmente por policiais.

13 Declaração feita durante o seminário "Jornalismo de Risco no Brasil: Tim Lopes, 10 anos depois" realizado nos dias 31 de maio e 1 o de junho de 2012, na ESPM, no Centro do Rio de Janeiro.

${ }^{14}$ Segundo uma pesquisa desenvolvida pelo CESeC (Centro de Estudos de Segurança e Cidadania) em 2004 e 2006, a cobertura da violência, da segurança pública e da criminalidade realizada pela imprensa brasileira sofre de dependência em alto grau das informações policiais. A polícia é a 
que reforça a representação desses lugares como opostos da cidade formal, áreas no limiar da barbárie. A mídia tem desempenhado papel central na construção dessa representação negativa dos espaços populares da cidade. Abdicando da sua capacidade de integrar o tecido urbano, os repórteres da cidade têm reforçado a ideia de que é preciso um controle policial e militar sobre tais áreas.

A ideia de guerra civil, já arraigada no senso comum, como categoria apropriada para dar conta do clima de violência dos centros urbanos brasileiros, em especial do Rio de Janeiro, de tal forma conquistou o imaginário dos profissionais de imprensa que tivemos durante a primeira década do século XX - a despeito da estabilidade institucional do país e das boas relações que mantemos com nossos vizinhos - cursos voltados para profissionais da imprensa que trabalham em áreas com conflito armado deflagrado. Em 2006, por exemplo, o Sindicato dos Jornalistas Profissionais do Município do Rio de Janeiro e os dois sindicatos patronais - o de Rádio e TV e o de Jornais e Revistas - promoveram em parceria com o International News Safety Institute (INSI), durante quatro dias, um treinamento para jornalistas que trabalham em cobertura de episódios violentos. Cinquenta profissionais receberam as orientações de Heather Allen, uma ex-oficial das Forças Especiais do Exército Britânico que se especializou em treinar jornalistas de áreas conflagradas em diversos países. Durante o treinamento, os repórteres aprenderam técnicas de primeiros socorros (como reanimação, respiração boca a boca, cuidados ao mexer no corpo de um colega desacordado), tiveram orientações sobre como se comportar e buscar proteção em ambientes de conflito, receberam dicas de linguagem corporal e de como se posicionar em situações de tensão. Em um stand de tiros, os jornalistas tiveram experiências práticas que mostraram como alguns esconderijos são inúteis durante um tiroteio. Postes feitos de cimento, por exemplo, não resistem a tiros de fuzis e latarias de automóveis também não oferecem a menor resistência. Uma semana

fonte principal - se não a única - na maioria esmagadora das reportagens. Em 2004, uma análise de 2.514 textos publicados em nove jornais de três estados demonstrou que a polícia era a principal fonte ouvida em $32,5 \%$ dos casos. Quando eram desconsiderados os textos que não indicavam fontes - notas, rápidos registros de encontros de cadáveres, roubos e outras ocorrências, que compunham $24,8 \%$ da amostra - o percentual subia para $43,2 \%$. Em outro levantamento, realizado pelo CESeC em 2006 sobre oito jornais do Rio, 26,9\% dos 2.651 textos baseavam-se em informações policiais. Além destes, um grande número de notas, que compunham $34,6 \%$ da amostra, tinha como fontes os boletins de ocorrência. 0 relatório completo encontra-se em www.ucamcesec.com.br. 
depois, em parceria com a ABRAJI, os sindicatos patronais de São Paulo repetiram o treinamento, com mais cinquenta profissionais.

Conforme proposto por Maria Alice Rezende de Carvalho (1995b), uma cidade é pequena, do ponto de vista político, quando não consegue prover de cidadania as grandes massas, isto é, não consegue contê-las sob a sua lei e guarda. No diagnóstico apresentado pela autora, a violência nas grandes cidades brasileiras está associada à baixa legitimação da autoridade política do Estado, cujo "privatismo congênito" estreitou excessivamente a dimensão da polis, condenando praticamente toda a sociedade à condição de bárbaros. Por "cidade escassa" é designada sinteticamente a cidade que se torna objeto de disputa generalizada e violenta entre os seus habitantes. O tema clássico da reflexão política, que associa o problema da escassez à "guerra de todos contra todos", é reeditado pela autora. A expressão "cidade escassa" refere-se à dimensão residual da cidadania e à sua parca competência para articular os apetites sociais à vida política organizada.

Quando [...] são intensos os padrões de exclusão e grande parte da população não se reconhece como partícipe de uma trajetória coletiva, a cidade torna-se objeto da apropriação privatista, da predação e da rapinagem, lugar onde prosperam o ressentimento e a desconfiança sociais. Desenvolvese, então, a fragmentação da autoridade e o fortalecimento de inúmeras microssociedades com seus chefes e legalidades próprios; propaga-se a corrupção; observam-se a deslegitimação do monopólio do uso da violência pelo Estado e a generalização do conflito. (CARVALHO, 1995:6)

Marcelo Burgos (2005) afirma que o pós-industrialismo recolocou no centro do debate a especificidade da questão da integração urbana, invertendo a tônica preexistente que tendia a colocar como marginal experiências urbanas como a do Rio de Janeiro, onde o mercado de trabalho nunca foi capaz de substituir outras fontes culturais produtoras de solidariedade. A ênfase em conceitos que operam na chave da integração social e não na da luta de classes estaria ganhando, segundo o autor, um estatuto mais universal para se pensar as cidades brasileiras. A crise de solidariedade, provocada pelo desencaixe entre os interesses e o quadro político-institucional, que o conceito de "cidade escassa" quer tornar inteligível, segundo Burgos, aponta a ausência de cultura cívica como chave para se compreender a desordem urbana experimentada no cotidiano violento das grandes cidades brasileiras. O desafio político da integração social do 
espaço urbano, segundo o autor, remeteria à experiência da Chicago da virada do século XIX, quando se tomou contato com um tipo novo de violência urbana, oriunda de conflitos decorrentes da superposição entre culturas e territórios. “Guardadas as devidas diferenças, é o mesmo desafio à superação das fronteiras territoriais que precisa ser enfrentado no Brasil contemporâneo, e no Rio de Janeiro em particular" (Burgos, 2005:192).

Preocupados em captar a alma, as formas de socialização, do ambiente urbano, repórteres como João do Rio e Irineu Marinho - à maneira dos sociólogos ligados às teorias da interação - fizeram, no início do século passado, do território carioca o seu laboratório de investigação da natureza humana. Perambulando com inteligência, João do Rio e seus pares contemporâneos puderam traduzir a experiência urbana do Rio de Janeiro da belle époque. Movimentando-se pela cidade, os repórteres de então foram capazes de atenuar fronteiras sociais e intelectuais estabelecendo um léxico comum entre os citadinos. Se hoje as imaginações construídas sobre o Rio de Janeiro estão marcadas pelo vocabulário da guerra e pela ideia de uma cidade partida, no século passado a integração social da cidade foi pensada principalmente através do campo da cultura. Foram os repórteres aqueles que tentaram traduzir e integrar o mundo urbano oferecendo uma imagem na qual os cariocas se reconheciam. Se hoje esse desafio parece quase impossível, talvez seja válido olhar para o passado a fim de recolher algumas lições e imaginar caminhos possíveis. 


\title{
A cidade e seus olhares
}

\subsection{Allegro ma non troppo: o sonho do progresso e o imperativo da ordem}

\begin{abstract}
"De uma hora para a outra, a antiga cidade desapareceu e outra surgiu como se fosse obtida por uma mutação de teatro. Havia mesmo na coisa muito de cenografia."
\end{abstract}

Lima Barreto. Os Bruzundangas.

O historiador do futuro comentará, sorrindo - escreveu Euclides da Cunha - a "abdicação graciosa e belíssima de 13 de maio de 1888, em que o ministério conservador do Conselheiro João Alfredo cortou as últimas amarras do Império, abandonando-o na caudal irresistível das ideias republicanas "15. Para Euclides, a sociedade brasileira não repelia a aspiração política da República. Prorrogava-a apenas, começando a incorporá-la a partir do último quarto do século XIX. O que havia sido impertinente em 1822, inoportuno em 1831, aparecia para uma sociedade tomada pelo impulso tonificador da filosofia contemporânea como uma aspiração antiga que pôde remover "naturalmente, sem ruído" um trono que já não tinha mais onde se escorar. Os primeiros anos da República foram, no entanto, marcados por uma série contínua de crises políticas. E se tais conflitos políticos moderavam os anseios das reformas, as agitações econômicas por seu lado apuravam os elementos predispostos a "fome do ouro, a sede de riqueza" O massacre de Canudos, um sinal enviado para a maioria da população brasileira que vivia na hinterlândia, serviu como um aviso ${ }^{17}$. Os novos tipos de homens -

\footnotetext{
${ }^{15}$ CUNHA, Euclides da. À margem da história. Porto, Portugal: Ed. Lello Brasileira S.A., 1967.

16 "Conciliando essas duas características, o conservadorismo arejado e a cupidez material, podese conceber a imagem acabada do tipo social representativo por excelência do novo regime". SEVCENKO, Nicolau. Literatura como missão: tensões sociais e criação cultural na Primeira República. São Paulo: Editora Brasiliense, 1983. p. 26.

17 “Em Canudos, interior da Bahia, um líder carismático e messiânico, Antônio Conselheiro, reuniu milhares de sertanejos depois que a polícia o perseguiu por ter destruído listas de novos
} 
que iriam impulsionar silenciosamente a revolução que pôs em xeque as estruturas persistentes da sociedade colonial, visando à modernização e a instauração da ordem social competitiva - não estavam comprometidos com a defesa implacável dos direitos do cidadão $^{18}$. O recado dado pelas forças armadas, que se apresentavam como uma inteligência reformadora inspirada pelo positivismo foi claro: a República que nascia vinha pacificar, não educar ou socializar.

Sobre a sociedade de Bruzundanga, é difícil dizer qualquer coisa, pois "lá não há verdadeiramente sociedade estável. [...] Não há tradição, cultura acumulada,[...] são todos arrivistas, [...] tiranizados pela paixão de ganhar dinheiro, seja como for"19. A Bruzundanga que possui maiores e mais completos males, não livra a nós do Brasil de atentarmos aos nossos. A vontade da elite econômica brasileira de participar do crescimento e da mudança da economia mundial capitalista colocava como inimigo o que havia de arcaico e colonial na sociedade brasileira. Nos primeiros anos da República, sonhou-se com o progresso (o que significava alinhar-se com os padrões e o ritmo do desdobramento da economia europeia), mas a necessidade imperativa da ordem manteve, apesar do mundo urbano, um sistema de dominação que preservou o status quo da antiga ordem hierárquica. Para manter tudo como antes, era preciso mudar. O familismo, a dominação pessoal do dono de terra e de gente, no mundo

impostos decretados após a proclamação da República. O Conselheiro não gostara também de medidas secularizadoras adotadas pela República, como a separação entre Igreja e Estado, a secularização dos cemitérios e, sobretudo, a introdução do casamento civil. Em Canudos, ele tentou criar uma comunidade de santos onde as práticas religiosas tradicionais seriam preservadas e onde todos poderiam viver irmanados pela fé. Sua comunidade foi destruída a poder de canhões, em nome da República e da modernidade". In: CARVALHO, José Murilo de. Cidadania no Brasil: o longo caminho. 18a edição. Rio de Janeiro: Civilização Brasileira, 2014. p. 77.

18 "Os novos tipos de homens [...] se afirmam num primeiro momento, pelo élan, de "modernizar", compondo-se assim, através de compromissos tácitos, com as elites da "aristocracia agrária". Mais tarde, porém, evoluem para opções mais definidas e radicais, embora dissimuladas, pelas quais tentam implantar no Brasil as condições econômicas, jurídicas e políticas que são essenciais para a instauração da ordem social competitiva. Em nenhum dos momentos esse "espírito burguês" exige a defesa implacável dos direitos do cidadão. Porém, em ambos ele se volta, específica e concentradamente, contra o que havia de "arcaico" e de "colonial" tanto na superfície quanto no âmago da ordem social patrimonialista". FERNANDES, Florestan. A revolução burguesa no Brasil: ensaio de interpretação sociológica. São Paulo: Globo, 2005. p.46.

${ }^{19}$ BARRETO, Lima. Os Bruzundangas. São Paulo: Editora Brasiliense, 1956. p. 107. 
urbano seria substituído por modernas instituições de controle que teriam que lidar com os efeitos sociais do colapso da velha ordem ${ }^{20}$.

Meio século antes do advento da República, sob influências inglesa e francesa, imprime-se um ritmo civilizador na sociedade brasileira que marcaria o início da decadência do sistema rural patriarcal. Gilberto Freyre, no seu "Sobrados e Mucambos" ${ }^{21}$, mostra como nas cidades, a casa patriarcal perde muito de suas funções. As políticas municipais, por exemplo, no século XIX agiram no sentido de "defender" a rua das casas. Buscou-se uma europeização do Brasil, que na época da chegada da corte tinha, segundo Freyre, "uma paisagem mais africana $e$ asiática que europeia". Quando a casa-grande de engenho patriarcal se transforma em sobrado, há um afastamento entre as populações que estavam próximas na casa-grande, com o consequente desmantelamento das zonas de confraternização. Segundo Freyre, cada vez mais a rua vai se impondo em relação à casa. Isso é visível nos momentos de confraternização (procissão, festa de igreja, entrudo [carnaval]) que marcam um novo prestígio, o da rua. O espaço público vai se formatando, a despeito do antagonismo entre a casa (universo privado) e a rua (espaço público), que no começo da urbanização era serva da casa. Tal "servidão" foi sendo abandonada ao longo do século XIX. Retrocede o absolutismo do senhor patriarcal, que passa a dividir o prestígio social com presidentes de província, médicos, juízes, advogados e chefes de polícia. Uma multiplicidade de vozes surge no cenário urbano, esvaziando a voz do senhor patriarcal. Com maior urbanização a vida ficaria mais livre da rotina doméstica. No entanto, mesmo desprestigiada, a "casa" do século XIX continuou a influir sobre a formação social do brasileiro na cidade. A família invade o Estado e os filhos dos nobres de terra entram para as instâncias de poder da vida pública. Porém, segundo o autor, uma

\footnotetext{
20 "As modernas instituições de controle eram necessárias não apenas para preservar o status quo, o que em todo caso seria impossível, mas para lidar com os efeitos sociais do colapso da velha ordem. Nesse sentido, o desenvolvimento do aparato de repressão foi também progressivo e previdente. Possibilitou a elite política e econômica conservar a vantagem na guerra social, controlar os escravos e seus sucessores funcionais e manter a ralé acuada. O Brasil convive com os resultados até hoje." HOLLOWAY. Thomas. Polícia no Rio de Janeiro: repressão e resistência em uma cidade do século XIX. Tradução de Francisco de Castro Azevedo. Rio de Janeiro: FGV, 1997. p. 264.

${ }^{21}$ FREYRE, Gilberto. Sobrados e mucambos: decadência do patriarcado rural e desenvolvimento do urbano. Rio de Janeiro: José Olympio, 1985.
} 
vez no governo, tornam-se "desertores dessa aristocracia a qual não se identificavam mais". Freyre fala da ascensão do bacharel e do conflito entre pais e filhos - um conflito entre as gerações por conta dos novos valores que surgiam.

Para José Murilo de Carvalho (1980), o relacionamento do Estado Imperial com a agricultura de exportação de base escravista caracterizava-se pelo que chamou - usando uma expressão de Guerreiro Ramos - de dialética da ambiguidade. Independentemente da elite política, o Estado não podia sustentar-se sem a agricultura de exportação, pois era ela que gerava, através de impostos, $70 \%$ das rendas do governo-geral. Apesar da desvinculação parcial dos interesses dos membros da elite governamental dos interesses da grande propriedade escravista ou, nos casos mais extremos, da grande propriedade em si, o Estado imperial se tornaria, através de sua elite, um instrumento ao mesmo tempo de manutenção e de transformação das estruturas sociais ${ }^{22}$. Segundo José Murilo, o Brasil não era uma economia mercantil como a portuguesa que pudesse ser governada pela aliança de um estamento burocrático com comerciantes. Era uma economia de produtores agrícolas com mão de obra escrava e de criadores de gado com ou sem escravos. As bases do poder tinham que ser aqui redefinidas.

Frequentemente, em vez de conflito entre as autoridades e os grandes proprietários, havia entre eles conluio, dependência mútua. A autoridade máxima nas localidades, por exemplo, eram os capitães-mores das milícias. Esses capitães-mores eram de investidura real, mas sua escolha era sempre feita entre os representantes da grande propriedade. Havia, então, confusão, que era igualmente conivência, entre o poder do Estado e o poder privado dos proprietários ${ }^{23}$. (CARVALHO, 2014:28)

22 "Os magistrados, embora muitos fossem vinculados à propriedade da terra e fossem reconhecidos em geral como sustentáculos da ordem, não eram reconhecidos como legítimos representantes dos proprietários rurais [...] Na elite não-burocrática, principalmente entre os profissionais liberais que substituíram em massa os magistrados, havia igualmente uma facção que se desvinculava dos interesses da grande propriedade, não só de escravos, mas mesmo de terra. Seriam eles os radicais urbanos, tanto do Partido Liberal como do Partido Republicano do Rio de Janeiro, cujo mais articulado representante seria André Rebouças". CARVALHO, José Murilo de. A construção da ordem: a elite política imperial. Rio de Janeiro: Editora Campus, 1980. p. 180.

${ }^{23}$ Caio Prado Júnior em Formação do Brasil Contemporâneo sobre a organização das forças de segurança no Brasil colonial e sobre a simbiose que então se estabeleceu entre poder privado local e administração central: "As Forças Armadas das capitanias compunham-se da tropa de linha, das milícias e dos corpos de ordenanças. A primeira representa a tropa regular e profissional, permanentemente sob as armas. [...] As milícias são tropas auxiliares. [...] A última categoria das Forças Armadas eram as ordenanças, formadas por todo o resto da população masculina entre 18 e 60 anos, não alistada ainda na tropa de linha. [...] As patentes superiores 
Da mesma forma, a manutenção da ordem no interior não poderia ter sido conseguida sem a colaboração dos senhores de terra. A elite política, particularmente os magistrados, tinha que compactuar com os proprietários a fim de chegar a um arranjo que possibilitasse uma aparência de ordem, mesmo que profundamente injusta ${ }^{24}$. A criação da Guarda Nacional, por exemplo, teria esse sentido de barganha. Segundo José Murilo, criada em 1831, a Guarda Nacional era, sobretudo, um mecanismo de cooptar os proprietários rurais, mas servia também para transmitir aos guardas algum sentido de disciplina e de exercício de autoridade legal. Era uma organização militarizada que abrangia toda a população adulta masculina. Seus oficiais eram indicados pelo governo central entre as pessoas mais ricas dos municípios. Nela combinavam-se as influências do governo e dos grandes proprietários e comerciantes. Era grande o poder de pressão dos seus comandantes sobre os votantes que eram seus inferiores hierárquicos.

das ordenanças conservavam também as antigas denominações: capitão-mor [...] e sargentomor. Além das suas funções militares [...] as ordenanças têm um papel considerável na organização da colônia. [...] Sem exagero, pode-se afirmar que são elas que tornaram possível a ordem legal e administrativa nesse território imenso, de população dispersa e escassez de funcionários regulares. [...] Graças a ela a colônia se tornou governável. O que facilitou a tarefa das ordenanças, dando força efetiva à hierarquia que representam, e permitindo-lhes o exercício das funções que nelas encontramos, foi a preexistência na sociedade colonial de uma hierarquia social já estabelecida e universalmente reconhecida. [...] O aspecto da organização da colônia, disposta em "clãs" que se agrupam em torno dos poderosos senhores e mandões locais, os grandes proprietários, senhores de engenho ou fazendeiros. Tal estrutura social abriu caminho para o estabelecimento das ordenanças: não houve mais que oficializar esta situação de fato, constituir com aqueles "clãs" os corpos destas últimas. E foi o que se fez colocando chefes e mandões locais nos postos de comando das ordenanças. Revestidos de patentes e de uma parcela de autoridade pública, eles não só ganharam em prestígio e força, mas se tornaram em guardas da ordem e da lei que Ihes vinham ao encontro; e a administração, amputando-se talvez com esta delegação mais ou menos forçada de poderes, ganhava no entanto uma arma de grande alcance: punha a seu serviço uma força que não podia contrabalançar, e que de outra forma teria sido incontrolável. E com ela penetraria a fundo na massa da população, e teria efetivamente a direção da colônia. [Em nota] Revendo os nomes que encontramos nos postos de comandos dos corpos de ordenança, vamos descobrir neles a nata da população colonial, os seus expoentes econômicos e sociais. Esta regra é invariável em todos os setores do país". PRADO JÚNIOR, Caio. Formação do Brasil contemporâneo: Colônia. São Paulo: Companhia das Letras, 2011. p. 329-347.

24 "A unidade básica da elite formada na colônia portuguesa evitou conflitos mais sérios entre seus próprios membros, estabeleceu um cordão sanitário que mantinha localizados nos municípios ou nas províncias os principais movimentos contestatórios, resguardou a integridade do país e a estabilidade do governo central. CARVALHO, José Murilo de. A construção da ordem: a elite política imperial. Rio de Janeiro: Editora Campus, 1980. p. 182. 
A Primeira República ficou conhecida como "república dos coronéis". Coronel era o posto mais alto na hierarquia da Guarda Nacional. O coronel da Guarda era sempre a pessoa mais poderosa do município. Já no Império ele exercia grande influência política. Quando a Guarda perdeu sua natureza militar, restou-lhe o poder político de seus chefes. Coronel passou, então, a indicar simplesmente o chefe político local. O coronelismo era a aliança desses chefes com os presidentes dos estados e desses com o presidente da República. (CARVALHO, 2014:47)

Para Florestan Fernandes (2008), a marcha seguida pela instauração e pela evolução da ordem social competitiva no fim do Segundo Império e durante a Primeira República esteve ligada às condições de desenvolvimento da empresa agrária - "a grande fazenda de café" - nas zonas em crescimento econômico, demográfico e social acelerado. Não teria sido a acanhada e vacilante "burguesia" que ofereceria a base econômica e o fulcro jurídico-político da formação insipiente da ordem social competitiva. Mas sim o círculo dos grandes homens de negócios da época, os quais detinham em suas mãos as engrenagens da vida econômica e política. Por isso, segundo Florestan, ao mesmo tempo em que a dinamização final da crise do antigo regime veio do campo, dele também partiu a contenção ativa das tendências de reintegração da ordem social, desencadeadas ou inerentes a essa mesma crise.

As inovações institucionais e a eficácia da liberalização jurídicopolítica republicana foram circunscritas, na prática, às necessidades da adaptação da "grande-empresa agrária" ao regime de trabalho livre e às relações de troca no mercado de trabalho que ele pressupunha. Fora e acima disso, continuaram a imperar os modelos de comportamento, os ideais de vida e os hábitos de dominação patrimonialista, vigentes anteriormente na sociedade estamental e de castas. Para que a ordem social competitiva pudesse se expurgar desses influxos constritivos e perturbadores, consolidando-se numa direção especificamente "burguesa", "liberaldemocrática" e "urbana", impunha-se que surgisse nas cidades um sistema de produção que as equiparasse ao campo ou as tornasse independente dele. Tal condição se delineia lentamente e só demonstra certo vigor, malgrado as debilidades e as incertezas da industrialização, meio século depois da Abolição e da Proclamação da República. Nada podia impedir que o "coronelismo", como equivalente e substituto da "nobreza agrária", convertesse o sistema republicano-presidencialista numa transação com o antigo regime e, principalmente, que a ordem social competitiva se ajustasse às estruturas persistentes daquele regime. (FERNANDES, 2008:61)

No prefácio à sétima edição de "Coronelismo, enxada e voto”, José Murilo de Carvalho diz que a sensibilidade de Victor Nunes Leal para a dimensão histórica - que o faz caracterizar o fenômeno do coronelismo como sistema restrito a um momento específico de nossa vida política - evita que esta seja mais 
uma análise genética que vê na história do país, em sua cultura e sua história, permanências que o condenam à eterna infantilidade democrática. Para José Murilo, o enfoque de Victor Nunes Leal do coronelismo como sistema - que caracterizou a rede nacional de poder desenvolvida no período histórico que correspondeu à primeira experiência do federalismo - ilumina a conexão entre município, Estado e União, entre coronéis, governadores e presidente, ilumina o jogo de coerção e cooptação exercido nacionalmente e principalmente destaca esse fenômeno como um sintoma do falseamento do regime representativo no Brasil $^{25}$.

O coronelismo, nessa visão, não é simplesmente um fenômeno da política local, não é mandonismo. Para Victor Nunes Leal (1997), durante a Primeira República, a organização policial foi um dos mais sólidos sustentáculos do "coronelismo". Durante esse período histórico, a função das polícias militares não se limitou à manutenção da ordem no estado. Seu papel, como parte do aparelhamento policial, na preparação das campanhas eleitorais foi da maior importância e sobrelevou, muitas vezes, sua atribuição regular de manter a ordem. Segundo o autor, as polícias militares foram um apoio importante para o Estado no equilíbrio político da federação. O federalismo de 1891 deixou as funções policiais a cargo dos estados e cada um deles organizou livremente seu aparelhamento policial. Foi adotado, em regra, o princípio da livre nomeação dos chefes de polícia, delegados e subdelegados, o qual permaneceu no governo discricionário de 1930, na Segunda República, no Estado Novo. O resultado, segundo Victor Nunes, foi a subsistência da polícia partidária, que já vinha do Império, utilizada como instrumento habitual de ação política: a diferença é que passou a servir às situações estaduais, quando antes obedecia aos desígnios do governo central (1997:224).

\footnotetext{
25 “Há na tese e, por sinal, em toda a obra e na vida pública de Victor Nunes, uma como metateoria, um valor mais alevantado, que vai expresso no título original, rebaixado, por razões editoriais, a subtítulo "O município e o regime representativo no Brasil". Para além do coronelismo que, por sua definição, já era coisa do passado, havia a preocupação maior com a implantação no Brasil de um autêntico sistema representativo, isto é, da democracia política". CARVALHO, José Murilo de. Prefácio à sétima edição. In: NUNES, Victor. Coronelismo, enxada e voto: o município e regime representativo no Brasil. 7a edição. São Paulo: Companhia das Letras, 2012.
} 
Victor Nunes destaca que a começar de certa fase do período colonial, acentuando-se após a transladação da Corte e mais tarde a partir da lei de 1841, é crescente o reforço do aparelhamento judiciário e policial, especialmente do último $^{26}$. Tal fortalecimento do poder público teria correspondido, na Colônia, aos interesses da Metrópole; no Império, aos propósitos centralizadores e na República o mesmo processo consolidaria as situações políticas estaduais. Segundo o autor, o desprestígio das ordenanças, nos últimos tempos do regime colonial (quando já estava mais fortalecida a autoridade régia), e, depois, a partir da segunda metade do século XIX, o descrédito da Guarda Nacional não são mais do que reflexos do mesmo fenômeno: a progressiva decadência do poder privado, que, mediante um compromisso — já significativo do seu declínio —, encontrava naquelas organizações um meio institucional de expressão (1997:242). Em meados do século XIX, já dominada toda a organização da polícia pelo governo central, diretamente ou através dos presidentes de província, a Guarda Nacional não tardaria a tornar-se predominantemente e, depois, meramente honorífica e decorativa. Através da distribuição de patentes a correligionários, preveniam-se rebeldias ou premiavam-se devoções. O prestígio do título passou a constituir sedução muitas vezes infalível na técnica de captação dos chefes locais. A República continuaria a utilizar o processo durante muito tempo (1997:240).

\footnotetext{
26 "Segundo o código de 1832, cada comarca tinha um juiz de direito, e nas mais populosas podia haver até três, um dos quais seria o chefe de polícia; os juízes de direito eram nomeados pelo Imperador. [...] Parece indiscutível que aos conservadores não bastava uma reação fragmentária e cuja medida thes escapava, como a representada pelas leis dos prefeitos. Urgia reformar o Código de 1832 no plano nacional, dotando o Executivo de extensos poderes para manter a ordem pública e a unidade nacional, entendidos os conceitos de ordem pública e de unidade nacional segundo os critérios mais caros à mentalidade conservadora e centralizadora. Esse propósito foi atingido com a lei no 261, de 3 de dezembro de 1841. [...] [que] instituiu, no município da Corte e em cada província, um chefe de polícia, ao qual estavam subordinados os delegados e subdelegados, no número que fosse necessário, todos de livre nomeação do governo, na Corte, ou dos presidentes, nas províncias, não podendo recusar o encargo. [...] Ficaram confiadas aos delegados e subdelegados, além das policiais, funções de natureza judiciária. Finalmente, extinguiu a lei as juntas de paz e o júri de acusação e deu outras providências que o regulamento desenvolveu. [...] A reação contra o judiciarismo policial dos liberais de 1832, com as funções policiais entregues a juízes de paz eletivos, foi certamente excessiva com a inversão operada - o policialismo judiciário, confiadas às autoridades policiais funções nitidamente judiciárias. [...] A lei de 3 de dezembro não foi um simples código processual ou de organização judiciária e policial; foi, acima de tudo, um instrumento político, um poderoso aparelho de dominação, capaz, de dar ao governo vitórias eleitorais esmagadoras, estivesse no poder o partido conservador ou o liberal". NUNES, Victor. Coronelismo, enxada e voto: o município e regime representativo no Brasil. Rio de Janeiro: Nova Fronteira, 1997. p. 222-223.
} 
Nos primeiros anos da República, mantendo-se o imperativo da ordem conquistado em aliança com o poder privado dos grandes proprietários - o sonho do progresso iria estabelecer-se como a grande meta da sociedade brasileira. Querendo um andamento prestíssimo, caminhamos allegro ma non troppo. Como o "Leopardo" de Lampedusa, em aliança com o passado construímos o futuro possível. Apesar da resistência das nossas estruturas e elites "arcaicas", vimos chegar, com assombro, os novos tempos que apesar das permanências trariam profundas mudanças. No último quarto do século XIX, a cidade do Rio de Janeiro - a maior cidade brasileira - praticamente triplica a sua população. Passa-se de 275 mil habitantes em 1872 para 811 mil em 190027. Com a Abolição e a crise da economia cafeeira que a seguiu, uma enorme massa humana outrora presa àquela atividade afluiu ao maior centro urbano do país. "A atividade humana aumenta numa progressão pasmosa"28.

Segundo Sevcenko (1983), a mudança da natureza das atividades econômicas do Rio de Janeiro transformou-o no maior centro cosmopolita da nação, em íntimo contato com a produção e o comércio europeus e americanos, absorvendo-os e irradiando-os para todo o país ${ }^{29}$. Uma nova filosofia financeira nasce com a República, reclamando uma remodelação dos hábitos sociais e dos cuidados pessoais. "Uma verdadeira febre de consumo tomou conta da cidade, toda ela voltada para "a novidade", a "última moda" e os artigos dernier bateau” (1983:28). Era preciso ajustar a ampliação local dos recursos pecuniários com a expansão geral do comércio europeu. Fica claro para os novos personagens o anacronismo da velha estrutura urbana diante das demandas dos novos tempos (1983:29). Acompanhar o progresso significava alinhar-se com os padrões e o

${ }^{27}$ Tabela 3 - Brasil - evolução da rede de cidades com mais de cem mil habitantes de 1872 a 1991. RIBEIRO, Darcy. O Povo Brasileiro: A formação e o sentido de Brasil. 2a ed. São Paulo: Companhia das Letras, 1995.

${ }^{28}$ BILAC, Olavo. Crônica. In: Revista Kosmos, no1, 1904. Apud: SEVCENKO, Nicolau. Literatura como missão: tensões sociais e criação cultural na Primeira República. São Paulo: Editora Brasiliense, 1983. p. 27.

29 "A situação era realmente excepcional. A cidade do Rio de Janeiro abre o século XX, defrontando-se com perspectivas extremamente promissoras. Aproveitando-se de seu papel privilegiado na intermediação dos recursos da economia cafeeira e de sua condição de centro político do país, a sociedade carioca viu acumular-se no seu interior vastos recursos enraizados principalmente no comércio e nas finanças, mas derivando já também para as aplicações industriais". SEVCENKO, Nicolau. Literatura como missão: tensões sociais e criação cultural na Primeira República. São Paulo: Editora Brasiliense, 1983. p. 27. 
ritmo do desdobramento da economia europeia. Segundo o autor, a imagem do progresso - versão prática do conceito homólogo de civilização - se transforma na obsessão coletiva da nova burguesia. Somente oferecendo ao mundo uma imagem de plena credibilidade era possível drenar para o Brasil uma parcela proporcional da fartura, conforto e prosperidade em que já vivia o "mundo civilizado".

Pedia-se a regeneração da cidade, e por extensão, do país. Segundo Sevcenko, para o novo grupo social hegemônico o triunfo com a inauguração da Avenida Central e com a promulgação da lei da vacina obrigatória foi o marco inicial da transfiguração urbana da cidade do Rio de Janeiro. Conforme o autor, quatro princípios fundamentais regeram o transcurso dessa metamorfose: a condenação dos hábitos e costumes ligados pela memória à sociedade tradicional; a negação de todo e qualquer elemento de cultura popular que pudesse macular a imagem civilizada da sociedade dominante; uma política rigorosa de expulsão dos grupos populares da área central da cidade; e um cosmopolitismo agressivo, profundamente identificado com a vida parisiense (1983:30). Para Sevcenko, o resultado mais concreto desse processo de aburguesamento intensivo da paisagem carioca foi a criação de um espaço público central na cidade, completamente remodelado, embelezado, ajardinado e europeizado, que se desejou garantir com exclusividade para o convívio dos "argentários".

Em pouco tempo e com a ajuda dos jornalistas e dos correspondentes em Paris, a burguesia carioca se adapta ao seu novo equipamento urbano, abandonando as varandas e os salões coloniais para expandir a sua sociabilidade pelas novas avenidas, praças, palácios e jardins. [...] A identificação com o novo modo de vida é tal, que os seus beneficiários, encabeçados pelos jornalistas, procuram organizar-se para garantir a sua manutenção, exigir a sua extensão a todos os pontos mais distantes e mais recônditos da cidade e impedir retrocessos. (SEVCENKO, 1983:37)

Com o advento da República dá-se a passagem de relações sociais do tipo senhorial para relações sociais do tipo burguês. É esse conflito que aflora na sociedade e nas consciências nesse momento. Verifica-se a tendência à dissolução das formas tradicionais de solidariedade social, representadas pelas relações de grupos familiares, corporações profissionais, comunidades vicinais, relações de compadrio ou relações senhoriais de tutela. As relações sociais passam a ser mediadas em condições de quase exclusividade pelos padrões econômicos e mercantis, compatíveis com a nova ordem. Sem apreço à sociedade precedente, o 
novo homem que surgia na virada do século, mesmo mantendo o conservadorismo da sociedade tradicional, deu asas a cupidez material. A miragem do dinheiro, da rápida ascensão material, seria aquela a animar os corações.

Georg Simmel, escrevendo em 1896, identifica na experiência moderna uma subordinação crescente dos valores qualitativos pelos valores quantitativos. $\mathrm{Na}$ medida em que o dinheiro passou a compensar de modo igual toda a pluralidade das coisas, exprimindo todas as distinções qualitativas entre elas mediante distinções do quanto, deu-se paralelamente uma modificação na atitude espiritual dos homens imersos nessa nova economia (Simmel, 1998). Segundo o autor, talvez não haja nenhum fenômeno anímico que seja reservado de modo tão incondicional à cidade grande como o caráter blasé (Simmel, 2005). O dinheiro, instrumento que permite, apesar da sua indiferença uniforme, comprar o mais variado e o mais especial, estaria segundo Simmel a atrofiar a sensibilidade sutil para as atrações específicas e individuais das coisas, colocando de lado a pergunta sobre o valor qualitativo em favor da pergunta sobre o valor quantitativo. Tal arrogância blasé seria somente um reflexo psicológico desse fato. $\mathrm{Na}$ caracterização proposta pelo autor, a posição central que o dinheiro assume - por meio do crescimento enorme do círculo de objetos alcançáveis por ele - irradia a sua influência em vários traços característicos da vida moderna. Não reagir mais às diferenças e propriedades específicas dos objetos com uma graduação correspondente da sensação, mas sim senti-las de maneira nivelada e, por isso, com uma coloração abafada, sem amplitudes significantes de contrastes, seria mais uma das consequências da vigência dessa nova configuração econômica. A economia monetária a exigir operações matemáticas contínuas no comportamento social do dia-a-dia fará do dinheiro o único valor vigente, o deus moderno.

Se o dinheiro conferiu um caráter impessoal a toda atividade econômica, por outro lado, aumentou a autonomia e a independência individuais. As conexões entre personalidades e relações objetivas - conexões típicas do que o autor chama de "tempos de economia natural" - desfaziam-se na economia do dinheiro. Esta última interpondo em cada instante, entre pessoa e coisa, a instância totalmente objetiva e não qualitativa em si mesma do dinheiro e do valor monetário. $\mathrm{O}$ exemplo apresentado por Simmel, da corporação medieval (que integrava o homem por inteiro), substituída pelo sindicato (organização praticamente 
desconhecida na Idade Média, que concentrava os aspectos impessoais dos indivíduos para a realização de determinada ação), não poderia ser mais representativo das mudanças de que trata. Segundo Simmel, os sindicatos não teriam tido seu enorme sucesso sem o concurso da economia monetária. O dinheiro teria nos ensinado como reunir sem nada perder de específico e próprio da personalidade. A objetividade pura nas atividades da associação, isto é, o seu caráter puramente técnico, independente de colaboração pessoal, libertou o sujeito de laços constrangedores, dado que este seria, agora, vinculado ao todo, principalmente pela doação e recepção de dinheiro e não mais como pessoa por inteiro.

Simmel alerta àqueles que lamentam o efeito separador e alienador do intercâmbio monetário a não esquecerem o fato de que o dinheiro gera uma ligação extremamente forte entre os membros de um setor econômico. Na medida em que o dinheiro possibilita a divisão do trabalho, ele encadeia os homens de maneira irresistível. Somente o trabalho de todos gera a união econômica abrangente que completa os desempenhos unilaterais do indivíduo. " $O$ dinheiro instaura incomparavelmente mais laços entre os homens que nos estágios da associação feudal e da reunião arbitrária, ambos louvados pelos românticos da associação" (Simmel, 1998:5). Conforme sua caracterização da época moderna, a organização monetária possibilitou, diferentemente dos tempos nos quais cada relação externa era simultaneamente pessoal, uma distinção mais pura entre a ação econômica objetiva do homem e a sua personalidade individual - esta última cada vez mais recolhida às esferas mais íntimas. A personalidade, mais solta da rigidez de laços e de tradições, pôde flutuar por meio de uma variedade múltipla de situações da vida.

E foram muitas e diversas as situações que os habitantes do Rio de Janeiro viveram então. Em poucos anos, mudara a feição da cidade. Maria Alice Rezende de Carvalho (2012), falando sobre João Marinho, pai do jornalista Irineu, e sua experiência na cidade de Niterói, destaca essa mudança pela qual iriam passar as nossas cidades nos primeiros anos do século XX. Nem grande nem pequena, nem pobre nem rica, nem totalmente provinciana, nem rendida ao cosmopolitismo da corte, Niterói era uma cidade média que, àquela altura, materializava um conjunto de disposições urbanas amparadas em redes de solidariedade e benevolência 
orquestradas por políticos, vizinhos ou compadres. Sob essa proteção, as dificuldades econômicas eram enfrentadas sem rebaixamento de status. Apesar da proximidade do Rio de Janeiro, de Niterói não era possível observar com clareza as mudanças que já tomavam de assalto a capital do país.

Tão integrado àquele universo, João Marinho não terá sido capaz de perceber os novos ventos que sacudiam as cidades. A propaganda abolicionista e republicana era apenas um sintoma do que estava por vir. $\mathrm{O}$ mundo mudara e as grandes correntes de pensamento que, por aquela época, recortavam o Ocidente se afinavam com a emergência da indústria, da sociedade de classes, das lutas sociais que prenunciavam o advento das primeiras cidades massivas da história. A urbe enfim, não será mais o campo da reciprocidade, como a vivenciara João Marinho. Será o lugar do crescente individualismo, da instabilidade de posições, das fantasias de sucesso, das loterias e jogos de azar, da miséria estacionada em chafarizes públicos e da emergência de novos ricos, sem apreço pela sociedade hierárquica que o amparara até então. (CARVALHO, 2012:37).

Maria Alice nos diz que essa nova configuração urbana somente será percebida em todas as suas dimensões e efeitos, pela geração seguinte, a de Irineu Marinho. A tradução da nova ambiência da cidade irá impor uma linguagem própria ao jornalismo do século XX. Essa nova imprensa, moderna e popular, da qual Irineu Marinho será talvez o mais representativo dos personagens, ao diferenciar-se da imprensa do contexto imperial e afirmar-se como um negócio e uma profissão, criará uma nova forma de contar a cidade. A partir da observação das ruas, com um texto mais ágil, e com um olhar mais atento ao instante, ao drama da novidade, os repórteres - esses novos personagens da vida urbana reivindicarão para si a primazia na interpretação do Rio de Janeiro moderno. 


\title{
2.2
}

\section{Reportagem: um modo de contar a cidade}

\begin{abstract}
A rua é a transformadora das línguas. [...] A rua continua, matando substantivos, transformando a significação dos termos, impondo aos dicionários as palavras que inventa, criando o calão que é o patrimônio clássico dos léxicons futuros.
\end{abstract}

João do Rio. A alma encantadora das ruas.

"Somos o único caso histórico de uma nacionalidade feita por uma teoria política $^{30}$." A visão acurada, ímpar, de Euclides da Cunha sobre o Brasil, pôde perceber no alvorecer do período republicano a importância da imaginação intelectual na formação da nossa nacionalidade. Quando afirma que somos filhos de uma teoria política, Euclides não ilumina apenas a importância das ideias na nossa constituição como povo, mas também a própria ausência de um povo-nação quando do momento crucial da nossa Independência. Segundo Euclides, o Brasil era amplo demais para os seus três milhões de habitantes que apesar da contiguidade territorial tinham destinos separados, faltando uma uniformidade de ideias e sentimentos que conformassem uma pátria. As "formações mestiças de três raças divergentes" chegavam ao período analisado com traços denunciadores de nacionalidades distintas, apesar de certa uniformidade mental, moral e social da Colônia, devido à influência católica e do sistema de escravidão. Seria - segundo o escritor - a "figura histórica tão deselegante e vulgar" de D. João VI, que quando acossado pela invasão napoleônica foge com a corte lusitana para o Brasil, aquela que teria lançado todos os fundamentos essenciais do nosso destino.

Antes mesmo dos primeiros surtos nativistas nacionais - à parte a “irritação" pernambucana de 1817 - serem, como diz Euclides, aferroados pelo liberalismo do Porto, já estávamos condenados à civilização. A própria transferência da corte para o Brasil e a sua elevação a Reino, deram-lhe como que seu destino o ser no Novo Mundo uma nação como as europeias. E quando da crise que nos levaria à Independência, Euclides destaca que nesse momento histórico se confundiam, "penetrando-se entrelaçados", o ideal da Independência

\footnotetext{
${ }^{30}$ Euclides da Cunha, Da Independência à República. In À margem da história. Porto, Portugal: Ed. Lello Brasileira S.A., 1967.
} 
e o da unidade nacional, sendo um equilíbrio possível apenas através da dinastia real. O "equilíbrio dinâmico" possibilitado pela intervenção monárquica permitiria que a passos de formiga fôssemos cumprindo nosso destino. Por termos violado, segundo Euclides, a ordem natural dos fatos, a nossa integridade étnica teria de constituir-se e manter-se garantida pela evolução social. Estávamos condenados à civilização, sendo a alternativa ao progresso o desaparecimento. As reformas liberais, "descendo a golpes de decretos", seriam impostas por homens que mais do que representantes do país eram representantes do seu tempo, livres das tradições nacionais - que na verdade não existiam - "arrebatava-os a miragem do futuro". Nossa primeira constituição, não sendo um traço de aliança na solidariedade do povo, "era um trabalho todo subjetivo, ou capricho de minoria erudita discorrendo dedutivamente sobre alguns preceitos abstratos, alheia ao modo de ser da maioria (Cunha, 1967)". Segundo Euclides, a esses homens acorreu uma intuição genial que esclareceu-os da tarefa estranha de formar uma nacionalidade sem a própria base orgânica da unidade de raça.

A nossa única tradição generalizada era a do ódio ao dominador recente ainda em armas, e esta, servindo como recurso de momento no propagar a rebeldia, extinguir-se-ia com a vitória, deixando aos formadores da nova pátria um problema ainda mais formidável: erguer, unido ao regime constitucional, novo na própria Europa, um povo disperso, que não atravessara uma só das fases sociais preparatórias. Um salto desmesurado e perigoso. (Cunha, 1967: 192)

Segundo Euclides, aqueles eruditos, com os olhos fixos na Europa e no constitucionalismo nascente, reuniram na Constituição de 1824 as melhores conquistas liberais adornando-as com exageros democráticos, tornando-as inatingíveis para a cultura do país. Esses homens tinham cravado um marco ao longe no futuro e desde então nossa história tem sido um fatigante esforço para o alcançar. Nesse ensaio, Euclides ao mencionar o distanciamento entre governo e sociedade, referindo-se ao século que findava, foi buscar um antecedente histórico para expor o diagnóstico crítico sobre a conjuntura em que vivia. Para além da denúncia desiludida de um republicano convicto que se via frente a uma República excludente e oligárquica, o diagnóstico que Euclides elabora sobre a origem do Brasil moderno evidencia a força produtiva das ideias, das imagens elaboradas sobre a vida social. Segundo o autor dos Sertões, nascemos de uma 
teoria, somos filhos de uma ideia. Tal ideia colocada em movimento teve impacto, produziu fatos, criou caminhos e possibilidades.

A grande influência das ideias no destino da nação não é exclusividade brasileira. Tocqueville analisando como, em meados do século XVIII, os literatos franceses tornaram-se os principais homens políticos do país e os efeitos que disso resultaram, afirma que gradualmente a imaginação da multidão desertou a sociedade real - cuja constituição era ainda tradicional, confusa e irregular - para recolher-se numa sociedade imaginária na qual tudo parecia simples e coordenado conforme a razão. "Desinteressaram-se do que era e puseram-se a pensar no que podia ser, e por fim viveram pelo espírito naquela cidade ideal que os escritores haviam construído ${ }^{31}$ ". A influência exercida pelos philosophes na sociedade francesa irá, como nos conta Tocqueville, resultar naquilo que o autor mais temia: o processo revolucionário. De tanto se falar em ódio social tal categoria passa a fazer parte da realidade francesa, sendo impossível a partir daí frear a revolução.

Aproximando-nos de nossos vizinhos de continente, Angel Rama - figura singular do latino-americanismo - foi dos poucos que, mesmo reconhecendo as particularidades brasileiras, produziu um discurso que insere a história do Brasil na história latino-americana em geral ${ }^{32}$. Segundo o autor, a descoberta de um novo continente, cuja cultura foi facilmente ignorada pela "cegueira antropológica", constituiu uma oportunidade de instaurar "modelos ideais de cidades" presentes na imaginação europeia (Rama, 2015). À impossibilidade de construir no velho continente esta cidade ideal, somou-se a oportunidade única de aplicar o princípio da tabula rasa nas terras virgens de um enorme continente. Em uma terra sem o peso do passado, o poder legitimou-se na simbologia da escrita. Cidades regidas pelas letras, ou melhor, regidas pelos homens capazes de dominar a escrita, evidenciam uma ordem que de certa maneira estaria presente na América Ibérica até os dias de hoje.

Estudando a concepção, o planejamento e a consolidação das cidades latino-americanas, desde a destruição da capital asteca, em 1521, até a

\footnotetext{
${ }^{31}$ TOCQUEVILLE, Alexis de. O Antigo Regime e a Revolução. Org. J. P. Mayer; trad. Rosemary Costhek Abílio. São Paulo: Editora WMF Martins Fontes, 2009. Pg. 161.

${ }^{32}$ RAMA, Angel. A cidade das letras. Editora Boitempo, 2015.
} 
inauguração de Brasília, na década de 1960, Angel Rama mostra como as cidades do novo continente foram idealizadas e racionalmente estruturadas como um sonho de ordem, desejo antigo dos europeus em sua conquista por uma cidade ideal, em contraposição às caóticas cidades renascentistas. A cidade barroca - tipo ideal proposto pelo autor para caracterizar esse novo modelo de cidade - seria totalmente diversa da cidade orgânica medieval, pois teria se formado a partir de um molde de cultura universal. Seria na verdade uma utopia. Como "páginas em branco" oferecidas aos colonizadores, as cidades latino-americanas inseridas em um ciclo de cultura universal figuram na análise do autor como um "parto da inteligência", como um sonho de ordem que teria encontrado nas terras do novo continente o único lugar propício para encarnar. $\mathrm{O}$ autor apresenta a problemática da cidade como signo, definindo-a no contexto continental como concretização singular do sonho colonizador de uma ordem e de um poder.

Na caracterização proposta por Angel Rama, a cidade ibero-americana teve sua origem na edificação da era capitalista europeia, estando indissociavelmente ligada às especificidades que esse processo apresentou na Península Ibérica. Sua concepção se deve mais a uma atividade do espírito, expressa nas palavras e não nas coisas reais, do que a uma acomodação à constituição física e cultural do novo mundo. Rama afirma que a modernização dessas cidades - entre a década de 1870 e a de 1920 - não alterou o marco geral da sua origem, qual seja, a prevalência da ordem dos signos sobre a ordem material. Com esses autores e na trilha do argumento que se irá apresentar, podemos afirmar que os intelectuais são criadores de imaginações poderosas que agem materialmente sobre o mundo. $\mathrm{E}$ se tais imagens não são necessariamente verdadeiras, nada garante que elas serão menos eficazes e persuasivas.

Maria Alice Rezende de Carvalho ao analisar a construção intelectual do Rio de Janeiro diz ser extensa a lista de cronistas cariocas que procuraram caracterizar a cidade, desde o final do século XIX, e que sua intenção ao evocar alguns autores envolvidos na tarefa de traduzir aquele mundo, àquela hora, é tão somente a de propor certas hipóteses sobre "a origem daquilo que se afirma ser a expressão da singularidade do Rio de Janeiro" (Carvalho, 1985). Ou seja, a autora irá procurar as origens das imagens mobilizadas para falar do Rio de Janeiro e que estiveram - e estão ainda hoje - presentes no debate público da 
cidade. Nessa incursão, ela sugere que "a produção e a reprodução das imagens consensuais sobre esta cidade [o Rio de Janeiro] estão, também, associadas à atuação de um tipo de intelectual cujo lugar social e posto de observação prioritário foi, originalmente, a rua e não as instituições. ${ }^{33}$ " Segundo a autora, no Rio de Janeiro do início do século XX, a exemplo do que ocorreu com os intelectuais franceses sob o Ancien Régime, a ausência de mecanismos de incorporação da intelligentzia à vida institucional pode ter contribuído para que a narrativa sobre a cidade se desenvolvesse sem os controles tradicionalmente operados pelas elites.

Maria Alice sustenta que a atividade intelectual no Rio de Janeiro enfrentou condições bastante diversas das que se desenvolveram em outras cidades brasileiras, nas quais as elites econômicas ou políticas mantiveram a cultura sob controle institucional. Diversamente de São Paulo, onde os intelectuais estavam voltados para a defesa e a expansão do complexo econômico cafeeiro, o Rio de Janeiro durante seu período de modernização não teve como referência predominante a realidade do mundo da produção. Segundo Maria Alice, a ideia de modernização que prevaleceu na produção intelectual dos cariocas esteve ligada à constituição de um novo pacto político exigido pelo regime republicano e que deveria encontrar na Capital Federal o cenário para a sua viabilização. No Rio de Janeiro, em contraste com a trajetória paulista - onde a ideia de mercado foi a “ficção" consensual -, a modernização não produziu modificações significativas na estrutura da sociedade. De tal modo que os intelectuais cariocas puderam figurar as ruas da Capital Federal como "uma ambiência organizadora $e$ educativa dos homens, afeita a uma "legalidade" e a um padrão de socialização alternativos à realidade institucional”. A conclusão, nos diz a autora, é previsível: sem elites políticas aptas a dirigir o processo de modernização, e diante da impossibilidade de a sociedade produzir, ela mesma, uma "alternativa "regeneradora" da ambiência moderna", caberia aos intelectuais o governo da cidade.

Aqui, portanto, a ideia de modernização não se fez acompanhar de um profundo processo de reformulação do tecido social, capaz de redefinir radicalmente a feição da cidade. Ao contrário, a cidade reformulava-se -

${ }^{33}$ CARVALHO, Maria Alice Rezende de. Quatro vezes cidade. Rio de Janeiro: Sette Letras, 1985. Pg 31. 
expressando-me nos termos de Angel Rama ${ }^{34}$-, na letra de seus intelectuais e na prancheta de seus engenheiros, sem que o mercado tivesse determinado a identidade e o lugar preciso de novos agentes sociais. (CARVALHO, 1985:36)

A atividade dos intelectuais cariocas, fundada, portanto, originalmente na observação das ruas seria a força diretiva a organizar a nova ambiência da cidade. A relação dessa intelligentzia com a cidade não trilhou o caminho das instituições, mas, antes, procurou a cumplicidade na "imaginação". A tradução do drama social vivido - que não se daria sem tensões e antagonismos - não serviu apenas à imprensa, universidade, ou à literatura (agências com a missão de compreender e explicar os eventos sociais), serviu também ao próprio desenrolar dessa modernização que adquiriu uma linguagem e a partir daí pôde se reproduzir no mundo ${ }^{35}$.

Essa imaginação que se criava sobre a cidade teve como reduto principal a imprensa carioca. Foi nela que, em larga medida, a intelligentzia da ville encontrou espaço para produzir e influir no mundo. O fato de João do Rio e Lima Barreto, por exemplo, serem jornalistas e escreverem com um texto ágil e moderno sobre eventos importantes do Rio de Janeiro - além de desmarcar a cronologia proposta pelo modernismo paulista - evidencia a forma como se articulavam "os de baixo e os de cima" na capital federal, ou seja, como se dava a integração sociocultural da cidade. Esse modernismo carioca, mais antigo e menos elitista que o paulista, associou aspectos do repertório popular às formas mais modernas de comunicação que se expunham não somente no jornalismo, mas também na literatura, na música e etc. Maria Alice falando sobre Irineu Marinho, seu jornal A Noite e sobre a própria cidade do Rio de Janeiro nas primeiras décadas do século XX, afirma que juntos esses personagens constituem uma boa chave para decifrar a moderna experiência cultural na capital da República (Carvalho, 2012). Com suas reportagens fotográficas, charges e textos ágeis, A

\footnotetext{
${ }^{34} \mathrm{~A}$ autora se refere ao livro A cidade das letras de Angel Rama, ed.1985.

${ }^{35}$ Maria Alice diz que em resumo a ambiência intelectual da belle époque carioca e as suas referências à cidade podem ser sintetizadas em torno de quatro pontos principais: (a) a constatação de que estava em curso um processo inédito de transformações da cidade; (b) o diálogo com e o questionamento da noção oficial de progresso; (c) a proximidade e a identificação dos intelectuais "sem lugar" com a situação dos excluídos, e; (d) a crescente sensação de que não seria desses seres que se extrairiam as bases de uma regeneração dos laços de solidariedade. Maria Alice Rezende de Carvalho. Quatro vezes cidade. op cit. Pg.41
} 
Noite teria constituído uma espécie de "língua franca" capaz de atenuar fronteiras sociais e intelectuais da cidade. Segundo a autora, são as figuras do repórter, da imprensa profissional e popular, e de um território socialmente mesclado que permitem entrever os andaimes de um mercado de notícias e entretenimento em construção, que na sua origem não separou radicalmente elite e povo, alta e baixa cultura, produção cultural de massa e prestígio intelectual.

Com seus textos fluidos, versando sobre um repertório do mundo urbano, esses intelectuais foram aqueles que conseguiram mobilizar imagens eficazes para falar do Rio de Janeiro, traduzindo o cenário cultural carioca que oferecia certa liberdade às criações populares, sem que, no entanto, tais atores do mundo popular pudessem de fato se expressar politicamente no espaço público. Segundo Maria Alice, o sucesso daquele que é considerado o primeiro samba gravado da nossa história, "Pelo telefone", é um exemplo ilustrativo da integração dos redutos populares à vida institucionalizada da capital federal através de uma rede de mediadores, constituída especialmente por jornalistas e teatrólogos, que traduzia aquele mundo - das agremiações, das "Tias" do samba - para o público mais amplo $^{36}$. Importa notar que a mediação também se dava em sentido inverso, os repórteres levavam para a população acercada das "tias" notícias e reportagens sobre outras partes da cidade. A letra de "Pelo telefone", com seu núcleo construído a partir de duas matérias publicadas no jornal A Noite - a primeira, uma reportagem sobre o jogo da roleta (publicada em 1913) e a segunda, uma nota (publicada em outubro de 1916) - seria um caso exemplar da integração dessa nova imprensa com a vida urbana, em especial com seus setores populares.

A intenção dos repórteres de A Noite ao produzirem tais matérias seria apontar a falta de fiscalização policial nas casas de jogo e em cassinos clandestinos da cidade, chegando a denunciar a ligação de políticos com proprietários de máquinas caça-níqueis. De acordo com essas reportagens, havia cerca de cinco mil pontos de jogo ilegal no Rio de Janeiro. Sob a retranca "o jogo é franco", a série de reportagens teve uma repercussão espetacular. O assunto se estendeu nas páginas de A Noite por vários dias, inclusive com desmentidos e

\footnotetext{
36 "Assim faziam muitos profissionais da imprensa, inclusive o repórter Mauro de Almeida. Um dos primeiros jornalistas dedicados especialmente à crônica do carnaval, noticiando eventos, contendas, [...] tornando visível um continente subterrâneo da cidade". Maria Alice Rezende de Carvalho. Irineu Marinho: imprensa e cidade. Pg.142.
} 
declarações do chefe de polícia, extravasando o âmbito dos leitores e envolvendo um conjunto maior de habitantes da cidade que acolheu as reportagens como tópico de conversas propagadas por toda parte.

Entender o sucesso desse samba significa perceber a presença de A Noite na cidade, sua circulação entre diferentes grupos e por diversos bairros, a familiaridade de seus repórteres com os redutos populares, sua penetração em terreiros, sociedades recreativas e instituições similares. Significa também perceber a sutil fronteira entre informação e comunicação, muito visitada por A Noite. Afinal, para o êxito de "Pelo telefone" foi decisivo o fato de "toda a cidade" conhecer o chamado episódio da roleta, encenação manhosa de dois repórteres de A Noite em pleno Largo da Carioca. (CARVALHO, 2012:139)

Segundo a autora, o efeito não previsto do samba foi que os textos jornalísticos, uma vez transformados em canções populares, levaram a crítica muito além do contingente relativamente restrito de leitores. Essa apropriação popular evidencia o modo de elaboração da notícia praticado por essa nova imprensa. Para os repórteres de A Noite, "notícia" não era apenas o relato de um fato, "mas a construção de um problema de grande apelo público, mediante abordagens curiosas, extravagantes, elas mesmas "noticiáveis", 37. Essa moderna imprensa popular - caracterizada por Maria Alice através do periódico lançado em 1911 por Irineu Marinho -, com sua linguagem ágil, acessível, que utilizava-se de fotografias, charges e caricaturas, teria conquistado o público carioca, principalmente, através de uma das suas grandes inovações; a realização de reportagens investigativas.

$\mathrm{Na}$ produção dessas narrativas, a equipe do jornal chegava a interferir diretamente nos fatos, com seus repórteres atuando incógnitos para, por exemplo, fazer uma denúncia ${ }^{38}$. Com tal procedimento, as matérias tinham o foco ora no problema em questão, ora na construção jornalística do problema. As mais memoráveis dessas campanhas, em que o narrador é parte da cena narrada, foram

\footnotetext{
${ }^{37}$ Op cit. Pg. 144

38 No livro que trata da trajetória do jornal, Maria Alice destaca reportagens como Palácio dos Suplícios, na qual um jornalista se internou num asilo para mostrar o tratamento aos internos; Fazedoras de Anjos, que contou com uma colaboradora do jornal para denunciar a prática ilegal do aborto; Como é fácil roubar!, na qual os repórteres conseguiram furtar vários objetos de museus e bibliotecas cariocas, demonstrando como era frágil o sistema de segurança dessas instituições; Duas semanas entre os mendigos, sobre a indústria da mendicância no Rio de Janeiro; entre outras. In. Maria Alice Rezende de Carvalho. Irineu Marinho: imprensa e cidade. São Paulo: Globo, 2012. Pgs 139-159.
} 
as reportagens que ficaram conhecidas como as do Faquir d'A Noite [que pretendeu denunciar a atuação de charlatões na cidade] e da Roleta da Carioca. A utilização de recursos dramatúrgicos, o enlace entre reportagem e drama, realidade e ficção, evidencia a intenção de tocar a sensibilidade da população do Rio de Janeiro, o que segundo Maria Alice, ajuda a compreender o sucesso de mercado do jornal que originalmente não tinha lastro econômico. Teatralização, espetacularização e boa dose de moralização, que segundo a socióloga, foram aspectos da estratégia comunicativa posta em prática pela imprensa norte americana e europeia no início do século $\mathrm{XX}$, no Brasil, com a devida aclimatação, teria vestido também o jornalismo praticado por Irineu Marinho.

Com a profissionalização dos jornais, mudava também o seu padrão editorial: a defesa de princípios perdia o lugar proeminente que detivera no século XIX, sendo substituídos por denúncias e, mais ainda, por reportagens que pretendiam falar diretamente ao coração do leitor. Daí o apreço dos novos jornais por crimes, fatos extraordinários, curiosidades científicas, fenômenos paranormais e prodígios circenses. A essa modalidade de escrita se deu o nome de fait-divers, sendo ela a característica comum à imprensa no período. (CARVALHO, 2012:47)

Segundo a caracterização apresentada por Roland Barthes (1964), tudo é dado num fait-divers $^{39}$. Não é preciso conhecer nada do mundo para consumir um fait-divers, ele não remete formalmente a nada além dele próprio. Trata-se de uma estrutura fechada. Como informação total, ou mais exatamente, imanente, ele contém em si todo seu saber. Sem duração e sem contexto ele constitui um ser imediato, total, que não remete, pelo menos formalmente, a nada de implícito. Evidentemente, seu conteúdo não é estranho ao mundo: desastres, assassinatos, raptos, agressões, acidentes, roubos, esquisitices, tudo isso remete ao homem, a sua história, seus fantasmas, sonhos e medos. Tal conteúdo não poderia deixar de ser mobilizado pela imprensa moderna e popular, essa que se estruturou em fins do século XIX, com sua intenção manifesta de atingir as grandes massas.

Pierre Bourdieu falando sobre o mesmo período histórico, afirma que o campo jornalístico constituiu-se como tal em torno da oposição entre os jornais que ofereciam antes de tudo "notícias sensacionalistas" e jornais que propunham análises e "comentários”, aplicados em marcar sua distinção com relação aos

\footnotetext{
${ }^{39}$ A estrutura dos fait divers. BARTHES, Roland. Essais critiques. Paris: Seuil, 1964, disponível em: http://www.eca.usp.br/jorlingrad/estrutura\%20barthes.doc
} 
primeiros afirmando abertamente valores de objetividade (Bourdieu, 1997:105). A oposição entre duas lógicas e dois princípios de legitimação - o reconhecimento pelos pares e o reconhecimento pela maioria - marcaria os primeiros anos dessa nova imprensa. A reportagem - uma inovação introduzida àquela época - seria quase um gênero ficcional, um ramo da literatura realista, desenvolvido também na tensão entre objetividade e mobilização das emoções, entre verdade e sensacionalismo. Essa espécie de ficcionalização da realidade - reforçada contemporaneamente pelo viés do entretenimento - seria um fenômeno constitutivo do jornalismo moderno. Já no final do século XIX, esse jornal - que vinha se tornando economicamente independente - deixava de ser exclusivamente uma plataforma política dos seus acionistas e estabelecia-se como empresa ligada ao ramo do entretenimento. O jornal moderno havia sido feito para vender e os empresários desse novo ramo de negócios entenderam que deviam mobilizar emoções se quisessem incrementar as vendas. Apresentando os fatos do dia como uma narrativa, uma história a ser contada, o jornal procurou prender a atenção do público com algo que mexesse com sua emoção. A reportagem esse novo modo de ver e contar a cidade se conforma, portanto, na tensão entre informação e ficção, na tensão entre o intuito de traduzir e compreender a cidade moderna e o de teatralizá-la nas páginas dos jornais.

No Brasil, tal processo de modernização da imprensa - concomitante ao processo de modernização da cidade - se dá de maneira bem diferente da que se deu nos países centrais, a começar pelo público leitor que será menor ${ }^{40}$. De toda forma, também tivemos por aqui empresários que tentaram imprimir algumas das características dessa nova imprensa, com forte influência norte americana. Para além da incorporação de avanços tecnológicos e editoriais, era preciso, sobretudo, investir no recrutamento de uma gente audaz, dinâmica e disposta a aprender e a

\footnotetext{
40 "A escassez do público brasileiro é atestável pelas tiragens dos jornais. No início do século XX, as cinco folhas mais importantes da capital federal - Jornal do Brasil, Jornal do Commercio, Gazeta de Notícias, Correio da Manhã e o Paíz - conformavam juntas, uma tiragem de 100 a 150 mil exemplares, enquanto o jornal inglês Daily Mail sozinho atingia a marca de 600 mil exemplares. No caso do New York Journal, os números são ainda mais espetaculares, pois durante a cobertura jornalística da Guerra Hispano-americana de 1898, o jornal teve tiragem superiores a um milhão de exemplares!" Maria Alice Rezende de Carvalho. Irineu Marinho: imprensa e cidade. op cit.Pg. 46.
} 
crescer junto com a empresa ${ }^{41}$. O repórter talvez seja o principal personagem desse contexto. Ele vai se apresentar pela primeira vez na cena urbana - antes não havia repórter, havia o colaborador do jornal -, como uma figura ágil, que está sempre próxima dos acontecimentos, pronta a identificar o drama urbano e transformá-lo em manchete ${ }^{42}$. O repórter será aquele a ficcionalizar, estilizar, os acontecimentos da cidade. Se a criação pela imprensa de imagens e imaginações sobre a cidade não pôde ainda ser associada a uma ideia de verdade, de maneira alguma isso diminuiu a sua eficácia como um dos operadores do pensamento que então se estabelecia acerca do urbano.

O historiador Robert Darnton (1987) escrevendo sobre o submundo que vivia da produção e difusão de literatura ilegal na França pré-revolucionária afirma que fazer mitos, ou desfazê-los, revelaram-se forças poderosas nos últimos anos de um regime que, apesar de absolutista em teoria, na prática se tornara progressivamente vulnerável às oscilações da opinião pública. Darnton pondera que o "público" francês do século XVIII não existia de forma organizada e, por menos que existisse nessa condição, fora excluído de qualquer participação direta na política. Dessa exclusão resultara uma candidez política que o tornava ainda mais permeável ao gazetismo do underground. A mentalidade dos subliteratos condenados à clandestinidade teria se exprimido com excepcional veemência nos últimos anos do Ancien Régime através do libelle - o principal meio de vida do subliterato, seu ganha-pão e gênero favorito. Um gênero que, segundo o autor, merece ser resgatado da negligência dos historiadores, pois comunica a visão de mundo dessa boemia literária ${ }^{43}$.

\footnotetext{
${ }^{41}$ Maria Alice Rezende de Carvalho. Irineu Marinho: imprensa e cidade. op cit. Pg. 40.

${ }^{42}$ Op cit. Pg. 49.

${ }^{43}$ A monarquia degenerara em despotismo, eis a mensagem que saltava de cada página. Morande, um dos autores resgatados por Darnton, continuamente destacava a ligação entre corrupção sexual e corrupção política. A crônica de adultério, sodomia, incesto e impotência nas classes altas pode ser lida, segundo o historiador, como indiciamento da ordem social. A decadência da aristocracia estava associada a sua incompetência no exército, na Igreja e no Estado. Os autores desse underground detestavam o sistema em si mesmo e exprimiam seu ódio dessacralizando símbolos, destruindo os mitos que o legitimavam aos olhos do público e perpetrando o contramito do despotismo degenerado. Segundo Darnton, o sensacionalismo sexual era portador de mensagem social: a aristocracia degenerara a ponto de não conseguir reproduzir-se.
} 
Robert Darnton afirma que se nos anos de 1789 e 1791, a Revolução pôs em prática muitas das ideias propagadas pelo Alto Iluminismo, no ápice de seu revolucionarismo, ela expressou as paixões antielitistas maturadas nesse underground. O Iluminismo que também era um programa para a difusão das luzes - ou seja, uma tentativa de propagar ideias entre o publico em geral, e não apenas refiná-las entre os filósofos - necessitava desses pobres-diabos como seus arautos e propagadores. Esses subliteratos carregavam material bem mais copioso que o dos philosophes e provavelmente de efeito mais direto na opinião pública. A demanda pela literatura proibida, a atração exercida pelo tabu, teria ajudado a minar o Ancien Régime, embora a luta de seus autores fosse uma luta banal pela sobrevivência. Tanto os philosophes quanto os libellistes foram sediciosos a sua maneira. Cada qual desses campos opostos, segundo Darnton, merece lugar nas origens intelectuais da Revolução ${ }^{44}$.

Para além da caracterização desse intelectual ligado às ruas e com acesso impedido às instituições, o método que o historiador propõe para captar o contexto intelectual que analisa pode ser profícuo para o entendimento do nosso objeto - a reportagem policial no Rio de Janeiro. Em " $O$ grande massacre de gatos e outros episódios da história cultural francesa", Darnton tenta mostrar como pensavam os franceses no período pré revolucionário, como interpretavam o mundo, conferiam-lhe significado e lhe infundiam emoção. Darnton afirma que nesse livro sobre mentalidades na França do século XVIII, ao colocar Diderot e Rousseau ao lado dos contadores de histórias camponeses e dos plebeus matadores de gatos, abandonou a diferenciação habitual entre cultura de elite e cultura popular, e tentou mostrar como os intelectuais e as pessoas comuns lidavam com o mesmo tipo de problema. $\mathrm{O}$ autor propõe que a história cultural, seja praticada à maneira dos antropólogos que estudam as culturas exóticas. Uma história de tendência etnográfica ${ }^{45}$ que explore visões de mundo pouco familiares,

\footnotetext{
${ }^{44}$ É sintomático o depoimento do chefe de polícia de Paris, resgatado por Robert Darnton, afirmando que "os parisienses estavam mais propensos a acreditar nos boatos maliciosos e libelles que circulavam clandestinamente que nos fatos impressos e publicados por ordem ou com permissão do governo". (Darnton, 1987:201) Certamente é difícil, talvez impossível, medir o grau em que os libelles prejudicaram a fé do público na legitimidade do Ancien Régime. Poder-seia argumentar, como o próprio Robert Darnton aponta, que o público considerava esses livros sujos engraçados e mais nada.
} 
que estude a maneira como as pessoas comuns entendiam o mundo em um tempo já distante ${ }^{46}$.

Quando apresenta a história do burguês de Montpellier que registra e pretende apresentar a sua cidade aos possíveis leitores do seu guia, Darnton diz que cada frase desse texto expressa uma consciência estranha tentando ordenar um mundo que não existe mais, e que para penetrar essa consciência é preciso concentrar-se mais nos modos de descrever do que nos objetos descritos. "Nossa tarefa não é descobrir qual o verdadeiro aspecto de Montpellier em 1768, mas entender como nosso observador a observou" (Darnton, 2011:144). Quando voltamos nosso olhar para esses operadores do pensamento que então se estabelecia no Rio de Janeiro acerca do urbano, devemos atentar que surgia um novo olhar sobre a cidade que era o olhar do repórter. Os modos convencionais de contar a cidade, sobretudo a literatura romântica, passaram a conviver com uma linguagem que tinha como lugar de origem e posto de observação as ruas. Uma linguagem mais atenta ao efêmero, ao instante, ao escândalo, a tudo aquilo que poderia mobilizar e atrair os leitores para um jornal que agora deveria manter-se, sobretudo, com as receitas advindas de seus anúncios comerciais e de suas vendas avulsas.

Vemos, portanto, que no Rio de Janeiro da belle époque, quando os jornais se transformavam - com a profissionalização dos seus quadros e com o início de certa autonomia financeira - e a cidade vivia um período de transformação do espaço público, do modo de vida e da mentalidade dos seus moradores, as narrativas literárias, científicas e a própria narrativa jornalística disputavam pela

\footnotetext{
${ }^{45} \mathrm{O}$ método antropológico da história teria, segundo Darnton, um rigor próprio, mesmo quando parecesse a um cientista social suspeitosamente próximo da literatura. Deve-se partir da premissa de que a expressão individual ocorre dentro de um idioma geral, de que aprendemos a classificar as sensações e a entender as coisas pensando dentro de uma estrutura fornecida por nossa cultura. Operaríamos dentro de coações culturais, partilhando convenções de fala e maneiras de pensar. Ao historiador, portanto, deveria ser possível descobrir a dimensão social do pensamento e extrair a significação de documentos, passando do texto ao contexto e voltando ao primeiro, até abrir caminho através de um universo mental estranho.

46 "Como tentei ilustrar, ao explicar o massacre de gatos na Rua Saint-Sevérin, o momento mais promissor da pesquisa pode ser o de maior perplexidade. Quando deparamos com alguma coisa que nos parece inconcebível, podemos ter tropeçado num meio de acesso válido a uma mentalidade estranha. $E$, quando vencermos a perplexidade e alcançarmos o ponto de vista nativo, deveremos ser capazes de perambular através do seu universo simbólico. Entender qual é a piada, no caso de uma coisa tão pouco engraçada como uma matança ritual de gatos, é um primeiro passo no sentido da "captação" da cultura". (Darnton, 2011:335)
} 
primazia interpretativa daquele momento. Pouco a pouco diminui a importância da literatura como o instrumento principal de criação de um consenso semântico e de um espaço público comunicativo. Como registro discursivo, a literatura perde sua importância à medida que a reportagem emerge na cena urbana. A literatura que era a forma dominante de dizer a cidade não mais reinou sozinha no tratamento dispensado às ruas. Em certo sentido, a literatura se tornará subsidiária do enfoque que repórteres começaram a emprestar àquele domínio ${ }^{47}$. A perspectiva do repórter, que vai procurar nas ruas os dramas humanos, daquele que conta a história, que retrata os fatos, é aquela que vai presidir as narrativas sobre a cidade moderna. Segundo Maria Alice Rezende de Carvalho, a agilidade, a nova linguagem e a profissionalização atestam a renovação da imprensa carioca, embora "coisa nenhuma nessa transição tenha sido feita rapidamente" 48 . Por longo tempo as reportagens conviverão com longos artigos de opinião marcados, principalmente, pela presença dos literatos no meio jornalístico.

Não se dá sem tensão o aparecimento de um novo conjunto de observadores e de tradutores da cena urbana. Em um interessante livro chamado "As três culturas", é descrito o debate entre dois grupos de intelectuais: literatos, isto é, escritores e críticos, de um lado, e cientistas sociais, sobretudo sociólogos, de outro. Desde a metade do século XIX, a literatura e a sociologia teriam disputado a primazia de fornecer a orientação-chave da civilização moderna, o direito de ser a doutrina de vida apropriada à sociedade industrial. Wolf Lepenies, o autor desse livro, afirma que nessa competição de interpretações revelou-se um dilema da sociologia: a hesitação entre uma orientação cientificista, pronta a imitar as ciências naturais, e uma atitude hermenêutica, que aproxima a disciplina da literatura. Nesse debate, em cujo decorrer foi se distinguindo o modo de produção científico do modo de produção literário, evidenciou-se uma competição de interpretações entre uma intelectualidade literária e uma intelectualidade ligada à ciência social. $\mathrm{O}$ problema da sociologia estaria no fato de que ela pode sem dúvida imitar as ciências naturais, mas não pode efetivamente tornar-se uma ciência natural da sociedade. Se renunciar à sua orientação científica, ela retorna a

\footnotetext{
${ }^{47}$ Desse período, um exemplo notório é o romance Casa de Pensão, de Aluizio Azevedo, que é uma reconstrução ficcional de um crime que ocorreu no Centro do Rio de Janeiro e foi fartamente noticiado pela imprensa.

${ }^{48}$ Maria Alice Rezende de Carvalho. Irineu Marinho: imprensa e cidade. op cit. Pg. 51
} 
uma perigosa proximidade com a literatura. Esse processo que Lepenies identifica de substituição ou de tensão entre modelos interpretativos da modernidade, de certa forma, também se deu na relação entre literatura e imprensa moderna.

De modo predominante, durante o século XIX os literatos colaboram com a imprensa, e no XX dá-se uma inversão entre os personagens - o escritor e o repórter - e a imprensa passa a informar a literatura. Como visto, essa nova imprensa de característica popular que passou a reivindicar as ruas como objeto jornalístico trará não só um novo modo de contar a cidade, mas também um novo personagem. Até então, os artigos de jornal eram produzidos por literatos. Os repórteres transformaram o jeito de dar notícia, substituindo a retórica e o linguajar empolado pelo drama da novidade. Como nos conta Maria Alice Rezende de Carvalho, Irineu Marinho chegava à imprensa naquele momento. Para Irineu, pertencer à imprensa significava agir como um repórter, e não como um letrado $^{49}$. Entre 1903 e 1904, Irineu participou do esforço de institucionalização profissional dessa categoria. A criação do Círculo dos Repórteres - entidade que Irineu ajudou a fundar e de que se tornou secretário - conferiu visibilidade àquele grupo profissional e segundo Carvalho, teria sido peça importante na construção da "nova imprensa" ${ }^{50}$. Em 1908, a criação da Associação Brasileira de Imprensa ABI, atestará o fortalecimento do setor.

O repórter que se afastava dos rituais da boemia, tinha muito cuidado com a sua caracterização, com a sua afirmação como um novo personagem urbano. Em contexto em que esse ethos profissional estava sendo erigido, era preciso que o repórter se diferenciasse do boêmio. Esse profissional, tradutor de uma nova configuração urbana que impôs uma linguagem própria ao jornalismo, foi dos primeiros a perceber as transformações por que passava a cidade e a incorporá-las ao seu ofício, levando a cidade para dentro da imprensa e vice-versa. As grandes cidades, que então surgiam como o lugar da economia monetária, atualizavam a

\footnotetext{
49 "Desde então, a frequência aos "cafés em pé" - e tudo o que derivava disso: o ritmo, a postura corporal, a substituição da conversa por comentários, a pilhéria - se colará de tal forma à imagem pública de Irineu Marinho, que, ao falarem dele, seus amigos recorrerão aos mesmos adjetivos de que se valeu, primeiro, Félix Pacheco: "Irineu Marinho, esguio e afanoso repórter [...], sempre apressado, mal se detendo à beira de uma roda para sorver, de corrida, um café entre duas observações mordazes"'". Maria Alice Rezende de Carvalho. Irineu Marinho: imprensa e cidade. op cit. Pg. 50.

${ }^{50}$ Maria Alice Rezende de Carvalho. Irineu Marinho: imprensa e cidade. op cit. Pg. 89.
} 
sua maneira o infinito repertório humano: a intensificação da vida nervosa, o caráter blasé, intelectualístico e econômico-monetário são fenômenos anímicos fortemente ligados à estrutura das grandes cidades que surgiam e que não passaram despercebidos aos olhos desses novos intérpretes ${ }^{51}$. Dessa geração de intelectuais que viveu a transição da boemia literária de fins do século XIX para a profissionalização de uma nova imprensa de característica popular, João do Rio será o personagem mais representativo. Reivindicando as ruas como objeto jornalístico, João do Rio procura mostrar nas suas crônicas uma sociabilidade que provém do espaço público, da rua, da relação que se estabelece entre a vida subjetiva dos citadinos e a materialidade urbana a que estão expostos.

O flanêur, conhecedor da cidade que transitava tanto nas altas esferas quanto nos locais degradados, foi dos primeiros a fazer sua carreira integralmente dentro da imprensa - quando o padrão era fazer da produção jornalística um complemento financeiro. João do Rio, com sua imaginação de repórter, apresenta na sua obra um tratamento intelectual da cidade do Rio de Janeiro sensível às transformações em curso. Pioneiro na imprensa brasileira do que hoje conhecemos por reportagem - um texto produzido a partir de situações observadas in loco e registradas através de um olhar que permita traduzi-las ao público leitor João do Rio teve destacada em pesquisa recente, como marca principal da sua obra, exatamente a postura de observador com que se apresentava ${ }^{52}$. Antes dele, a maioria dos textos publicados nos jornais eram produzidos dentro das redações, sem que houvesse no narrador qualquer postura investigativa. João do Rio teria revolucionado a imprensa brasileira nesse sentido, percebendo que a nova dinâmica urbana demandava um contato direto do jornalista com as ruas, de modo que os periódicos pudessem de fato chegar aos leitores, de modo a provocar identificação e interesse cotidianamente.

Foi João do Rio, aqui reconstruído analiticamente como representante de um grupo de intelectuais, aquele que percebeu que a rua é a transformadora das

\footnotetext{
${ }^{51}$ SIMMEL, Georg. As grandes cidades e a vida do espírito (1903). Mana 11.2 (2005): 577-591.

52 "João do Rio deve ser lido como um pensador social que, com seu temperamento etnográfico, anunciou questões que permeariam grande parte das análises clássicas acerca do desenvolvimento sociocultural do país". O'DONNELL, Julia Galli. No olho da rua: a etnografia urbana de João do Rio. Rio de Janeiro: UFRJ/ Museu Nacional, 2007.
} 
línguas. Que na interação que se dá entre os citadinos cria-se uma gramática, uma língua franca, capaz de ligá-los na e à cidade, conformando uma ambiência urbana - que nas palavras do autor - tem alma, é viva. A busca do flanêur pela alma da rua se dará pela observação in loco. João do Rio e seus pares contemporâneos - os repórteres - sairão das até então herméticas redações de jornais para captar nas delegacias, prisões, favelas, terreiros de umbanda, nas praças e esquinas o ar, a alma da cidade. Porém, antes de voltar-se com um olhar de estrangeiro para a sua própria realidade a fim de captá-la e traduzi-la, o repórter precisou - à maneira dos primeiros etnógrafos - distanciar-se fisicamente da cidade que o criara e que em breve iria coroar-lhe como seu mais profícuo leitor. 


\title{
2.3
}

\section{Turistas profissionais}

\begin{abstract}
É possível que das notas rápidas de um diário, em que os períodos não se alinham corretos, disciplinados e calmamente meditados, ressumbrem exageros; é possível mesmo que eu os releia mais tarde com surpresa. Mas nessa ocasião estarei como os que agora as leem fora do círculo hipnótico de um entusiasmo sincero e não terei, como agora tenho, diante de mim, a visão deslumbrante de uma pátria renegada.
\end{abstract}

Euclides da Cunha. Diário de uma expedição.

Tida como uma das mais sangrentas da história, a Batalha de Waterloo marcou o fim dos Cem Dias. Foi a última batalha de Napoleão Bonaparte após a fuga do exílio na ilha de Elba e seu retorno - em meio a aclamações populares - ao trono francês. Dez meses antes, em 11 de abril de 1814, o corso fora derrotado por uma coalizão de mais de 500 mil soldados de várias nações europeias. Vitoriosos, os aliados conduziram Luís XVIII ao trono da França e enviaram Bonaparte para o exílio. Em março de 1815, Napoleão reassume o poder enquanto as discussões do Congresso de Viena prosseguiam. Em 18 de Junho do mesmo ano, quando as tropas comandadas pelo Duque de Wellington encerraram vinte e três anos de luta entre a França e o resto da Europa, a notícia que todo velho continente queria receber era a do desenlace da batalha. Apesar de existirem na cidade de Londres em 1815 - cerca de 50 jornais e semanários, nenhum deles enviou ao menos um repórter para cobrir os eventos de Waterloo ${ }^{53}$. Sequer um único representante de um jornal britânico estava no campo de batalha, ou mesmo na sede dos aliados em Bruxelas. Somente três dias após a batalha, um mensageiro do Duque de

\footnotetext{
${ }^{53}$ Em 2015, a propósito das comemorações dos 200 anos da batalha, a emissora britânica BBC publicou uma matéria com algumas curiosidades sobre o evento histórico. Entre informações pitorescas como a do bio-historiador americano Arno Karlen, que acredita que Napoleão lidava naqueles dias com um grande caso de hemorroida que pode ter atrapalhado o seu desempenho e que "teria tornado um inferno até a simples tarefa de montar em seu cavalo", pode-se ler alguns dados interessantes como o da inexatidão geográfico-histórica com que o evento tem sido lembrado. A batalha de Waterloo não ocorreu de fato em Waterloo - em território que hoje é a Bélgica. A maior parte do combate se desenrolou poucos quilômetros ao sul, na localidade de Plancenoit. Waterloo foi onde o Duque de Wellington elaborou seu relatório de batalha, lançando o nome da cidade para a posteridade. Napoleão, portanto, nunca teria posto os pés em Waterloo. Disponível

em: http://www.bbc.com/portuguese/noticias/2015/06/150621_hemorroida_napoleao_waterloo_la b.shtml?ocid=socialflow_facebook
} 
Wellington chegou a Londres com a notícia da vitória. Nesse ínterim, todos os tipos de rumores se espalharam pela cidade.

Tratava-se, é certo, de uma grande notícia. As perdas na batalha foram muitas. Morreram aproximadamente 48 mil pessoas. Derrotado, Napoleão abdicou ao trono - pela segunda vez - do qual havia se proclamado imperador. Um grande evento histórico, talvez a notícia daquele início de século e, no entanto, não havia um único repórter à vista. O professor de história da Universidade de Kingston, Brian Cathcart, em artigo no jornal The Guardian ${ }^{54}$, afirma que nesse momento não se considerava parte do trabalho do jornalista testemunhar os acontecimentos pessoalmente. Segundo Cathcart, apenas recentemente começou a se associar o relato testemunhal de eventos com a própria ideia de jornalismo. Reportagem e jornalismo nem sempre estiveram tão intimamente conectados. Para o historiador, dentre as principais razões pelas quais os editores ingleses não enviaram repórteres para a Bélgica está a pressão exercida pelo governo para evitar tais iniciativas. Os jornais eram pequenas empresas e carregavam um pesado fardo de impostos. Em empresas não muito rentáveis, a maioria dos editores não teria sido capaz de manter um repórter no exterior por qualquer período de tempo. Apesar dessa situação, Cathcart acredita que se pudéssemos perguntar a um editor londrino, em 1815, porque ele não enviou um repórter para a Bélgica a fim de obter informações sobre a batalha, seria pouco provável que ele culpasse o governo. Ele provavelmente expressaria perplexidade, porque a ideia nunca teria passado pela sua cabeça. $O$ fato é que não era considerado parte do trabalho de um jornalista testemunhar pessoalmente os eventos.

"Em suma, jornalistas não andavam apressados com suas cadernetas, procurando notícias, abordando com perguntas céticas e digerindo o que eles encontravam em dedicadas e factuais reportagens. Notícias e jornalismo eram distintos, e eles iriam fundir-se apenas gradualmente nas décadas que se seguiram" ${ }^{\text {"55 }}$ (CATHCART, 2015).

\footnotetext{
${ }^{54}$ CATHCART, Brian. The Battle of Waterloo, and not a single reporter in sight. The Guardian, 2015. Disponivel em: http://www.theguardian.com/books/2015/may/15/battle-waterloo-newsaggregation-journalism-brian-cathcart

${ }^{55}$ No original: "In short, journalists did not rush about with notebooks, finding news, asking sceptical questions and digesting what they found into dedicated, factual reports. News and
} 
Contar a história dessa "fusão" é contar a história da imprensa moderna. Empresa do ramo do entretenimento, a imprensa que surgia junto com a cidade moderna, na necessidade de cativar seu leitor enxergou no drama da novidade o elemento que iria distingui-la das outras formas de contar o urbano e que poderia garantir ao jornal um lugar de destaque no coração dos citadinos. Narrando os fatos como série fantástica de acontecimentos, mesclando informação e ficção, tendo sempre em vista o prazer da leitura, o gênero por excelência desse veículo a reportagem - seria aquele a apresentar aos moradores da cidade o exótico, o distante, e claro a guerra e o crime. Com a missão de mobilizar emoções, os repórteres criam uma forma narrativa que, ainda quando ficcionalizada, é baseada na ideia de um sujeito que vê, que narra porque "esteve lá" e agora pode contar a novidade. A reportagem supõe o narrador presente no local dos acontecimentos, observando in loco o desenrolar dos fatos. Porém, tão difícil quanto estar no local, foi causar a impressão nos leitores que de fato se esteve lá. Como ocorreu aos primeiros etnógrafos, os repórteres precisaram desenvolver maneiras de afirmar que estiveram no local e de que tiveram contato próximo com os objetos de que tratam nas suas reportagens.

Hoje, guerras são também imagens e sons na sala de estar. Ser um espectador de calamidades ocorridas em outro país, segundo a filósofa norte americana Susan Sontag, é uma experiência moderna essencial, uma "dádiva acumulada durante mais de um século e meio graças a esses turistas profissionais e especializados conhecidos pelo nome de jornalistas". Em Diante da dor dos outros (2003), Sontag reflete sobre o efeito das imagens de sofrimento em nossas vidas e sobre como nós, espectadores, as encaramos. Em um dos capítulos, a filósofa apresenta a preocupação de Gustave Moynier, primeiro presidente do Comitê Internacional da Cruz Vermelha, que já em 1899 discutia como reagir ao incessante crescimento do fluxo de informações sobre as agonias de guerra. Segundo o humanista suíço, as informações transmitidas pelos jornais diários estariam colocando, por assim dizer, "aqueles que sofrem nos campos de batalha diante dos olhos dos leitores, em cujos ouvidos seus gritos ressoam". Nas memórias da infância passada na Inglaterra em meados do século XIX, o poeta

journalism were distinct, and they would merge only gradually in the decades that followed." Ibidem. 
inglês Edmund Gosse descreve como a Guerra da Crimeia penetrou no ambiente da sua família rigidamente religiosa e devota: "A declaração de guerra contra a Rússia trouxe o primeiro sopro de vida exterior para o nosso claustro calvinista. Meus pais assinaram um jornal diário, o que nunca haviam feito, e fatos em locais pitorescos, que meu pai e eu íamos procurar no mapa, eram debatidos com ardor." (Sontag, 2003:43).

Para Susan Sontag, algo se torna real - para quem está longe, acompanhando o fato em forma de "notícia" - ao ser fotografado. A compreensão da guerra entre pessoas que não vivenciaram uma guerra seria, contemporaneamente, sobretudo um produto do impacto dessas imagens. As fotos seriam meios de tornar "real" (ou "mais real") assuntos que as pessoas socialmente privilegiadas, ou simplesmente em segurança, talvez preferissem ignorar. "Olhem, dizem as fotos, é assim. É isto que a guerra faz" (Sontag, 2003:12). No Brasil, o biênio de 1877-78 marcou a história das secas no Nordeste. Tida como a maior daquele século, a seca atingiu grandes partes dos estados nordestinos e, em especial o Ceará. Segundo o artigo "Imagens da Seca de 187778 - Uma contribuição para o conhecimento do fotojornalismo na imprensa brasileira", dos pesquisadores Joaquim Marçal Ferreira de Andrade e Rosângela Logatto, a publicação de fotos de vítimas da maior seca nordestina do século XIX foi uma das iniciativas pioneiras da imprensa brasileira na utilização de fotografias como documentos comprobatórios de um fato. Segundo os autores, foi da imprensa nacional que partiram as vozes mais firmes de protesto contra aquele quadro de calamidade, reclamando recursos e providências do governo imperial.

Naquele ano de 1877, o carioca Gazeta de Notícias registrava em seu quadro de redatores o nome de José do Patrocínio, jornalista que se tornaria conhecido pelos discursos inflamados na campanha abolicionista ${ }^{56}$. Patrocínio começou na revisão, mas logo se destacou com Ocorrência de Rua, uma sessão policial, e a Gazeta Métrica, miniatura do noticiário político. No ano seguinte, José do Patrocínio seria o homem indicado pela redação do jornal para fazer a cobertura jornalística da tragédia que assolava o nordeste. Sua principal tarefa era acompanhar a aplicação de recursos do governo imperial no combate à seca. O

\footnotetext{
${ }^{56}$ Sobre a participação de José do Patrocínio na campanha abolicionista ver "Flores, Votos e Balas: o movimento pela abolição da escravidão no Brasil” de Angela Alonso, 2012.
} 
então jovem jornalista partiu em viagem a 13 de maio de 1878. Até alcançar o Ceará, o navio em que viajava fez várias escalas ao longo do litoral nordestino. Os artigos enviados à redação da Gazeta narravam os horrores presenciados pelo jornalista e eram publicados sempre ao pé da primeira página sob o título "Viagem ao Norte", encimados pela palavra "folhetim"57. A diagramação das páginas isolava esses artigos, criando um espaço diferenciado para eles e destacando a continuidade do que estava sendo apresentado. É interessante notar que tais reportagens - que recebiam um espaço de destaque no jornal e tinham um custo alto para a redação - fossem chamadas de folhetim. Esse movimento ao que hoje conhecemos como reportagem, obviamente, não ocorre de forma repentina ${ }^{58}$. Apesar de o objetivo da viagem de Patrocínio ser relatar o drama observado e fiscalizar a aplicação do dinheiro público no socorro às vítimas, seus textos não privilegiam a comunicação de fatos e o tom é todo subjetivo. Seu romantismo e helenismo, aos olhos do leitor contemporâneo, não denotam o respeito que a situação calamitosa narrada merecia. Alguns trechos da primeira reportagem da série, publicada em $1^{\circ}$ de junho de 1878 na Gazeta de Notícias, fazem esquecer o motivo de tal viagem ${ }^{59}$.

"Cheguei hoje à capital das Alagoas, sentindo espairecer-se-me o enjoo pertinaz em robusto apetite fradesco. [...] As remadas dos marinheiros possantes na baía, que arfava sem ruído, desabrochando ao longe em florescências de espuma, breve levavam-nos a uma ponte que se adianta pelas ondas e se termina em uma espécie de quiosque engradilado". (GAZETA DE NOTÍCIAS, $1^{\circ}$ de junho de 1878$)^{60}$

\footnotetext{
57 Fonte: Portal Brasiliana Fotográfica. Disponível em:

http://memoria.bn.br/DocReader/DocReader.aspx?bib=103730_01\&PagFis=4098

58 Dessa viagem ao norte do país também teve origem o romance de José do Patrocínio, Os Retirantes. Publicado na Gazeta de Notícias em estilo de folhetim, entre 29 de junho e 10 de dezembro de 1879.
}

59 GALVÃO, Walnice Nogueira. "O jornal dessa época acolhe em suas páginas material variadíssimo e que hoje se encontra disperso pelos outros veículos. É ao mesmo tempo um jornal mais literário e menos literário. Mais, porque nele são frequentes os contos, os poemas, as crônicas, e porque nele escreveram regularmente grandes nomes da criação literária [...] e menos: o estilo jornalístico, ainda muito pouco desenvolvido, peca a todo o momento pela incorreção da linguagem". (GALVÃO, 1994:17,18).

${ }^{60}$ Cópia digital do original disponível no site da Biblioteca Nacional:

http://memoria.bn.br/DocReader/DocReader.aspx?bib=103730_01\&PagFis=4098\&Pesq= 
Ainda no mesmo artigo, ao ouvir um "piano fanhoso", Patrocínio escreve: "não sei porque me veio a lembrança aqueles divinos versos de Garret: Longe, pelo azul dos vastos mares, // Eu vi gemer a lamentosa alcyone // E com ela gemeu minha saudade. E cerrei os olhos numa humanidade de lágrimas. Não só o formato textual, estilístico, das reportagens ainda não havia despontado na imprensa, como também pouca era a autoridade dessa voz (a do repórter) que buscava e espalhava informações. Segundo Andrade e Logatto, Patrocínio certamente desejava buscar cumplicidade para o triste espetáculo que presenciava, mas toda a eloquência de suas palavras não era suficiente. A Gazeta de Notícias era um jornal de texto, e as poucas ilustrações existentes despontavam na sessão de anúncios. O jornalista, então, enviou para a redação de $\mathrm{O}$ Besouro ${ }^{61}$ algumas fotografias de vítimas da tragédia da seca, que ilustravam aquilo que vinha narrando na Gazeta. Duas das fotografias foram reproduzidas na primeira página do número de 20 de julho de 1878. A ilustração litográfica, de autoria de Bordalo, mostra a mão de um esqueleto humano segurando duas fotografias que retratam crianças vítimas da seca sob o título "Páginas tristes - scenas e aspectos do Ceará (para S. Majestade, o Sr. Governo e os senhores Fornecedores verem)”. Logo abaixo, uma observação entre parênteses: “cópias fidelíssimas das fotografias que nos foram remetidas pelo nosso amigo e colega José do Patrocínio”. Na página seguinte à ilustração com as fotografias das vítimas da seca foi publicado um editorial, o qual reproduzo um trecho:

"O nosso amigo José do Patrocínio, em viagem por aquela província, enviou-nos as duas fotografias por que foram feitos os desenhos da nossa primeira página. São dois verdadeiros quadros de fome e miséria. É naquele estado que os retirantes chegam à capital, aonde quase sempre morrem, apesar dos apregoados socorros, que segundo informações exatas são distribuídos de maneira improfícua. A nossa estampa da primeira pagina é uma prova cabal aqueles que acusavam de exageração, a pintura que se fazia do estado da infeliz província. Repare o governo e repare o povo, na nossa estampa, que é a cópia fiel da desgraça da população cearense. Continuaremos a reproduzir o que o nosso distinto colega nos enviar a tal respeito.” (O BESOURO, 20 de julho de 1878) [grifo meu].

Segundo Andrade e Logatto, o resultado do conjunto (retratos + textos) seria um veemente panfleto que denunciava uma realidade que muitos membros da corte se negavam a enxergar. Para Susan Sontag, de fato, há muitos usos para

\footnotetext{
${ }^{61} \mathrm{Em}$ março de 1878, é anunciada a criação de uma nova revista no Rio de Janeiro, “O Besouro folha ilustrada, humorística e satyrica", pelo chargista português Rafael Bordalo Pinheiro.
} 
as inúmeras oportunidades oferecidas pela vida moderna de ver - à distância, por meio da fotografia - a dor de outras pessoas. Para a filósofa, fotos de uma atrocidade podem suscitar reações opostas. "Um apelo em favor da paz. Um clamor de vingança. Ou apenas a atordoada consciência, continuamente reabastecida por informações fotográficas, de que coisas terríveis acontecem"(Sontag, 2003:16). Por longo tempo as pessoas teriam acreditado que, se o horror pudesse ser apresentado de forma bastante nítida, a maioria das pessoas finalmente apreenderia toda a indignidade e a insanidade da guerra. Recrutadas como parte do jornalismo - periódicos já publicavam fotos desde 1880 -, contava-se com as imagens não só para atrair a atenção, o espanto, a surpresa dos leitores, mas também para atribuir valor documental às matérias jornalísticas ${ }^{62}$.

Segundo a historiadora Ana Maria Mauad, a partir da segunda metade do século XIX a fotografia foi transformada, entre tantos outros usos e funções, em documento. "Data deste período a sua utilização em reportagens militares. $O$ caráter de fidelidade à realidade atribuído à imagem fotográfica é tão patente que Mathew Brady, chefe da equipe que cobriu a Guerra Civil americana, considerou a câmera fotográfica como "o olho da história"” (Mauad, 1993:26). As fotografias produzidas nos campos de batalha tornavam-se testemunhas oculares de eventos até então só imaginados através de relatos escritos. Conforme Mauad, no Brasil, a prática de registrar conflitos e guerras, através da imagem fotográfica, data também do século XIX ${ }^{63}$. A primeira documentação fotográfica deste tipo "foi produzida durante a Guerra do Paraguai (1865-1870), seguida

\footnotetext{
${ }^{62}$ ANDRADE, Joaquim M.F.; LOGATTO, Rosângela. "Em meados dos anos 1860, durante a Guerra Civil norte americana - primeiro conflito armado a ser sistematicamente fotografado, do início ao fim - pelo menos dois periódicos ilustrados daquele país, o Frank Leslie's Illustrated Newspaper e o Harper's Weekly, se utilizaram desse recurso para sensibilizar a opinião pública acerca dos horrores da guerra". In: Imagens da seca de 1877-78 no Ceará: uma contribuição para o conhecimento das origens do fotojornalismo na imprensa brasileira. Anais da Biblioteca Nacional, v. 114, p. 71-83, 1994.

${ }^{63}$ SONTAG, Susan. "Nas primeiras guerras importantes registradas por fotógrafos, a Guerra da Crimeia e a Guerra Civil Americana, bem como em todas as guerras até a Primeira Guerra Mundial, o combate propriamente dito esteve fora do alcance das câmeras. As fotos de guerra publicadas entre 1914 e 1918, quase todas anônimas, eram, em geral - quando de fato transmitiam algo do terror e da devastação -, de estilo épico e, frequentemente, retratos das consequências: os cadáveres espalhados ou a paisagem lunar resultante de uma guerra de trincheiras". In. Diante da dor dos outros. Tradução Rubens Figueiredo. São Paulo: Companhia das Letras, 2003.
} 
pela ampla cobertura feita pelo fotógrafo Juan Gutierrez durante a Revolta da Armada (1893) e pelo registro minucioso da quarta expedição a Canudos $(1897)^{64}$. Posteriormente, tal procedimento tornou-se corrente, como pode ser constatado pela grande documentação fotográfica a respeito do conflito do Contestado (1910-1917)" (Mauad, 1993:26).

Sobre os registros fotográficos produzidos em Canudos, Ana Maria Mauad afirma que, como revelam pesquisas realizadas em jornais e revistas da época, as fotografias não tiveram divulgação contemporânea. Somente, posteriormente, foram utilizadas como ilustração de memórias históricas escritas por oficiais do Exército sobre a quarta campanha de Canudos. Segundo a historiadora, por falta de maior circulação, tais fotografias restringiram-se, à época, a criar uma memória do conflito própria ao consumo da corporação militar. Por outro lado, "é também sobre esta expedição que existe um maior número de relatos e crônicas, mobilizando um contingente razoável de intelectuais, encarregados de registrar o que foi a derrota final da resistência monárquica, como era divulgada na época a posição dos sertanejos" (Mauad, 1993:28).

O professor de Teorias da Comunicação da Pontifícia Universidade Católica do Rio Grande do Sul, Antonio Carlos Hohlfeldt fez um levantamento dos jornais então existentes e das características do jornalismo do final do século XIX para o início do século XX a fim de mostrar a importância da Campanha de Canudos e como a mesma foi percebida pela imprensa, que lhe deu ampla cobertura, tornando-se - segundo o professor - o primeiro evento midiático de nossa história ${ }^{65}$. Segundo Hohlfeldt (2009), Canudos torna-se notícia de jornal, sobretudo, a partir da derrota de Moreira César. No início do conflito, as fontes eram, em sua grande maioria, os próprios militares que escrevendo para as suas famílias expressavam a necessidade de manter informada a opinião pública e pediam que as informações enviadas fossem levadas até as redações dos jornais.

\footnotetext{
${ }^{64}$ MAUAD, Ana Maria. "As fotografias sobre Canudos foram produzidas pelo fotógrafo expedicionário, Flávio de Barros, durante a quarta empreitada militar. Elas estão organizadas em dois álbuns, com respectivamente 15 e 54 fotos e mais três avulsas". In: O olho da história: análise da imagem fotográfica na construção de uma memória sobre o conflito de Canudos. Acervo- Revista do Arquivo Nacional, Rio de Janeiro, v. 6, n. 1-2, p. 25-40, jan/dez 1993.

${ }^{65}$ GALVÃO, Walnice Nogueira. "A esta altura, o assunto é tão candente que 'Sobre Canudos' torna-se seção e passa a sair com regularidade" (GALVÃO, 1994, p. 59).
} 
Nesse momento, o que o leitor conhecia da rebeldia sertaneja era uma versão, se não oficial, ao menos oficiosa da luta, pois as fontes eram sempre militares republicanos. A derrota de Moreira César irá provocar a curiosidade dos jornais, que por seu lado reflete a curiosidade do leitor. Na etapa final da luta, a cobertura já contará com correspondentes regionais ou enviados especiais, que do campo de batalha colhiam informações e as transformavam em notícias ${ }^{66}$.

Walnice Nogueira Galvão reconhece que "a Guerra de Canudos, se não inaugurou, deve ter intensificado extraordinariamente no Brasil a praxe jornalística de dispor enviados especiais no local dos acontecimentos" (Galvão, 1994:109). O repórter Euclides da Cunha, enviado por Júlio Mesquita ${ }^{67}$ em nome de O Estado de São Paulo, já havia comentado o envio das tropas comandadas por Moreira César, colocando-se claramente contrário aos rebeldes e em favor da República ${ }^{68}$. Contudo, as observações de campo irão levar Euclides a profundas modificações na avaliação que fará do movimento, transformando seu preconceito inicial de republicano convicto em uma forte denúncia do abandono em que viviam as populações interioranas.

Depois que partiu do Rio de Janeiro, Euclides permaneceu 24 dias em Salvador, à espera do deslocamento para o interior ${ }^{69}$. Chegou a Belo Monte no dia

66 HOHLFELDT, Antonio Carlos. Dos correspondentes então enviados ao cenário da guerra: “a Gazeta de Notícias enviou Júlio Procópio Favila Nunes, gaúcho, que já cobrira a Revolta da Armada; O Estado de São Paulo escolheu Euclides da Cunha; o Jornal do Commmercio, do Rio de Janeiro, o pernambucano Manuel Benício; o sergipano Siqueira de Menezes, tenente-coronel, escreve para O País, sob o pseudônimo de Hoche; Lélis Piedade escreve para o Jornal de Notícias, de Salvador, além de Manuel de Figueiredo, Alfredo Silva e muitos outros, nem sempre identificados pelas respectivas redações". (2009:136).

67 HOHLFELDT, Antonio Carlos. "A Província de São Paulo participou ativamente da campanha republicana e logo após a proclamação da república, troca seu nome para O Estado de São Paulo. Foi o primeiro diário a ser vendido nas ruas da cidade, a partir de 23 de janeiro de 1876 . Em 1897, foi pioneiro na decisão de enviar um correspondente à Bahia para acompanhar os acontecimentos de Canudos. Júlio Mesquita que assumira a direção do jornal em 1891, tornar-seia proprietário do mesmo em 1902, dentre outros motivos, justamente por esta perspectiva mais aberta em relação ao jornalismo. Tratava-se, como registra Sylvio Rabello, "de uma inovação nos métodos do jornalismo: a reportagem colhida ao vivo"'”. (2009:139)

68 "A nossa Vendeia (1)" e "A nossa Vendeia (2)". Publicados originalmente em O Estado de São Paulo em 14 de março de 1897 e em 17 de Julho de 1897.

69 Durante a cobertura de Canudos, foram grandes as dificuldades para se enviar o material produzido pelos correspondentes em campo. Além da censura militar, os repórteres enfrentavam a distância entre Monte Santo e as bases dos jornais, em São Paulo ou Rio de Janeiro. Em O Estado de São Paulo, por exemplo, a cada artigo publicado, indicou-se sempre a data de 
6 de setembro de 1897, acompanhando a quarta e última expedição, comandada pelo general Artur Oscar de Andrade Guimarães. O jovem repórter passou menos de um mês em Canudos e não testemunhou o desfecho do conflito. Regressou a Salvador quatro dias antes da queda do arraial - a 5 de outubro - por sentir-se febril e adoentado. Embora tenha sido o último correspondente a chegar ao campo de batalha, Euclides acompanhou ao vivo tudo o que pode. Assim como os militares que participaram da campanha, ele padeceu com as péssimas condições do acampamento, com o clima hostil, com a escassez de água e comida, com os intensos tiroteios e o cheiro dos cadáveres putrefatos. Não se limitou a observar. Ele conversou, recolheu dados, fez suas anotações e interpretou. Assumindo a primeira pessoa do singular, desde o primeiro boletim, é enquanto depoimento pessoal que Euclides escreve. Hohlfeldt destaca a avaliação que Olímpio de Souza Andrade faz do trabalho do repórter Euclides da Cunha: “como repórter de gênio que nobilitava extraordinariamente a grande reportagem, enviou para o seu jornal as notas completas, perfeitas, de um realismo que, uma vez ou outra, contrariava a falsa opinião que daquilo tudo fazia o país inteiro, e o seu próprio jornal" (Hohlfeldt, 2009:140).

Uma espécie de "Conrad às avessas", como registra mais uma vez Olímpio de Souza Andrade, para evidenciar que Euclides da Cunha, ao contrário de Joseph Conrad (também repórter) foi muito mais crítico, sobretudo porque o jornalista teria abdicado - segundo o crítico - de toda e qualquer ficção, contrariando o que a imprensa aceitara como uma grande conjura monarquista agindo nos sertões baianos. Em carta a Joaquim Nabuco ${ }^{70}$, por ocasião do lançamento d'Os Sertões, Euclides pede que se releve no livro os deslizes na forma, pois esses empalidecerão na escala de sinceridade com que o autor esboçou suas páginas. Segundo Euclides, aí estaria o seu único valor. "Releve-me esta verdade, o Dante, para zurzir os desmandos de Florença idealizou o inferno; eu, não, para bater de frente alguns vícios do nosso singular momento histórico, copiei, copiei apenas,

procedência do texto. O primeiro artigo enviado por Euclides da Cunha é editado em 18 de agosto, mas fora enviado ainda a 10 de julho, portanto, mais de um mês antes. (Hohlfeldt, 2009:136)

70 CUNHA, Euclides. Carta a Joaquim Nabuco. Lorena, 18 de outubro de 1903. Disponível em: https://pt.wikisource.org/wiki/Correspond\%C3\%AAncia ativa de Euclides da Cunha_em 1903 \#Lorena.2C 18 de outubro de 1903 
incorruptivelmente um dos seus aspectos... e não tive um Virgílio a amparar-me ante o furor dos condenados! [grifo meu]”

À maneira dos etnógrafos, foi importante para Euclides - que tinha a intenção manifesta de manter certa fidelidade aos fatos e ao clima observado na região - a utilização de suas cadernetas de anotações, onde registrava rapidamente as primeiras impressões e que depois consultava quando desenvolvia o texto a ser enviado $^{71}$. Olímpio de Souza Andrade (Cunha, 2009) diz que tal caderninho é fonte de inexcedível valia para os estudos brasileiros em geral e para as pesquisas linguísticas e estilísticas, inclusive pelo que reúne em matéria de palavras e expressões usuais no sertão. A caderneta de campo de Euclides, segundo Olímpio, apresenta-se particularmente valiosa para o conhecimento do estilo e do método de trabalho do escritor. O documento revelaria um Euclides prevenido contra as traições da memória e as mentiras dos homens. Um repórter que confronta informações e se vale inclusive de desenhos ou esboços ligeiros muito bem traçados para auxiliar o raciocínio.

"[No caderninho] encontramos a sua frase ainda não apurada, a sua admirável probidade, o seu amor à verdade, quer através de leituras nas melhores fontes, quer mediante a incrível obstinação em conhecer de perto tudo quanto interessasse ao seu trabalho, ouvindo, vendo, anotando para não falsear pontos fundamentais da história que contava. Perseguindo depoimentos orais e escritos, copiando esses na íntegra, executava tal trabalho exaustivo para, não raro, ao final, utilizar-se de um trechinho, quando não os abandonava por insuficientes ou falsos". (ANDRADE, Olímpio de Souza. in CUNHA, 2009:34)

Em 1939, a editora José Olympio publicou o livro "Canudos: diário de uma expedição" com os artigos enviados por Euclides à redação do Estado de São Paulo. A introdução dessa edição é de Gilberto Freyre que compara o escritor a uma espécie de El Greco da prosa brasileira: tirando das palavras - como o outro do desenho e da tinta - o máximo de recursos esculturais. Porém, nesse diário de expedição, diz Freyre, Euclides se revela menos escultural na técnica de escrever e de interpretar tipos e cenários nos seus momentos grandiosos e nos seus aspectos heroicos, e mais fluido ao mesmo tempo que menos intolerante do cotidiano.

\footnotetext{
${ }^{71}$ CUNHA, Euclides (2009). "Escrevo rapidamente, mui rapidamente mesmo, acotovelado de quando em vez, por passageiros que passam, num coro de interjeições festivas, e nas quais meia dúzia de línguas se fundem no mesmo entusiasmo".
} 
Sente-se nas crônicas um gosto diverso do da obra madura e quase monotonamente lapidar: um gosto com a sua ponta de verde, o seu pico de espontaneidade, embora, de modo nenhum, de improvisação. [...] Não acredito na improvisação destas notas, muito menos na d'Os Sertões: improvisação afetada por Euclides com certa pacholice de Don Juan que ostentasse sucessos fáceis; com certa gabolice de adolescente. [...] Euclides tinha uma dificuldade tremenda em redigir. João Luso acompanhou-lhe uma vez a tortura de estilista redigindo com um vagar de quem fizesse renda um artigo para o Jornal do Commercio: "levou aquilo mais de três horas para ocupar no dia seguinte um resumido espaço no jornal". (CUNHA, 1939:17)

Uma ou outra nota - segundo Freyre - se destaca daquelas cartas pela emoção tumultuosa que verdadeiramente acuse a reportagem pura, em vez da "estilização pachorrenta". Em carta de 12 de agosto, Euclides escreve ter visto saltar do trem oitenta soldados feridos na estação. Freyre comenta que ao estilista como que faltou tempo para fazer parar toda essa gente ferida em figuras esculturais - embora ele não esqueça de salientar as "apófises dos ossos" a apontarem dos "corpos depauperados" dos "heróis obscuros". Gilberto Freyre, ainda nessa introdução de 1939, afirma ser evidente em Euclides da Cunha - o Euclides das cartas sobre a expedição a Canudos - traços de influência daquele tipo profundamente inglês de literatura - o "diário de militar". Militar que cumpre liturgicamente o seu dever de soldado, mas não renuncia à sua consciência de protestante inquieto a refugiar-se no diário como o católico no confessionário.

Raymond Firth, na segunda introdução (de 1988) ao polêmico "Diário no sentido estrito do termo" de Malinowski, apresenta um comentário de Anthony Forge - no artigo "The Lonely Anthropologist" - observando que embora se aprenda pouco sobre o método de pesquisa de campo no Diário, ele mostra muito bem o dilema de todo antropólogo no campo - reter sua própria identidade e ao mesmo tempo se envolver o máximo possível nos assuntos da sociedade local. Firth afirma que há um reconhecimento muito mais nítido hoje de que a posição do etnógrafo não é simplesmente a de alguém que registra a vida de uma sociedade, mas também de alguém que tanto afeta essa vida quanto é afetado por ela. Os primeiros etnógrafos - segundo ele - não desconheciam isso. Mas, naquele momento, a grande tarefa de descrever e analisar as instituições estranhas parecia mais importante do que discorrer sobre a percepção a respeito dos papéis desempenhados na situação etnográfica. Antes de Euclides - nos fala Freyre - a paisagem brasileira tivera entre os poetas e os romancistas os seus simpatizantes e até entusiastas: o maior deles José de Alencar. Porém, o autor d'Os Sertões foi o 
primeiro caso de verdadeira empatia. Ele não só acrescentou-se aos sertões como acrescentou os sertões para sempre a sua personalidade e ao caráter brasileiro. Seria “impossivel separar Euclides dessa paisagem-mãe que se deixou interpretar por ele e pelo seu amor como por ninguém”.

Pode-se afirmar que as coincidências que envolvem a emergência desses gêneros narrativos não são apenas cronológicas. A necessidade premente de observar o que será narrado está inscrita na origem tanto da etnografia, da literatura realista, quanto da reportagem. Na missão de anunciar aos leitores o drama da novidade, o jornalismo praticado pela geração dos primeiros repórteres para traduzir a nova ambiência social em forma narrativa se utilizou de práticas, hoje, associadas mais diretamente à etnografia. Da mesma forma, pode-se remontar a origem da reportagem às experiências estilísticas realizadas na literatura (o realismo social), que se associam direta ou indiretamente a uma espécie de trabalho de campo, a uma boa capacidade de observação e a um envolvimento direto com os sujeitos e as tramas sociais em que estes estão inseridos. Independente das aproximações analógicas, fato é que ao surgimento dessas formas narrativas concorreu não só o privilégio da visão sobre a audição característica dos tempos modernos, como sustenta a argumentação de Walter Benjamin -, mas também a própria ascensão do indivíduo moderno e de sua subjetividade. Tomar nota do que fora observado, vivenciado individualmente, e em seguida colocar no papel essa experiência é atitude do narrador moderno que marcou profundamente essas novas formas de observar e contar a ambiência social.

Segundo Hélio Silva (2009), ver, sendo diferente de olhar pura e simplesmente, implica uma organização do que foi olhado, espiado, percebido ao longo do percurso. Ver implica um olhar que se organiza. A matéria do olhar, isto é, o que o olhar modela, é a matéria do escrever, aquilo que a escrita modela. Enquanto anda e olha, o etnógrafo - e poderíamos acrescentar sem desvirtuar o argumento do autor, o repórter - está sendo teleologicamente movido para uma escrita e está permanentemente entrevendo uma tarefa ao cabo de tudo: escrever. "Uma etnografia, enquanto texto, não deixa de ser um olhar revisto ou, se a frase soar rebarbativa aos mais sensíveis, um olhar que revê. E revê porque está em outro ângulo" (Silva, 2009:182). Segundo o autor, o percurso no campo, sua 
observação e a descrição do contexto percorrido e observado são três fluxos que se misturam pela reciprocidade, interdependência e (inter) influências. Andar, ver e escrever, três fluxos que se encontram dinamicamente interrelacionados, a exercerem e sofrerem influências recíprocas. Tais atividades remetem a uma tripla e inextricável atividade do etnógrafo; sua circulação no campo, sua observação do campo e sua versão do que aconteceu ali e seus significados ${ }^{72}$.

Alguns etnógrafos - também pode-se afirmar, alguns repórteres - são mais eficientes do que outros em criar a impressão, em sua prosa, de que tiveram um contato estreito com vidas e locais distantes. Clifford Geertz diz que se houvesse um melhor entendimento do caráter literário da antropologia, alguns mitos profissionais sobre como ela consegue ser persuasiva tornar-se-iam insustentáveis. Em particular, talvez fosse difícil defender a visão de que os textos etnográficos convencem, na medida em que chegam a ser convincentes, pelo simples poder de sua substancialidade factual (2009:13). A capacidade dos antropólogos de nos fazer levar a sério o que dizem - segundo Geertz - tem menos a ver com uma aparência factual, ou com um ar de elegância conceitual, do que com sua capacidade de nos convencer de que o que eles dizem resulta de haverem realmente penetrado numa outra forma de vida - de realmente haverem, de um modo ou de outro, "estado lá". "E é aí, ao nos convencer de que esse milagre dos bastidores ocorreu, que entra a escrita" (2009:15).

Como nos conta James Clifford, ao fim do século XIX, nada garantia, a priori, o status do etnógrafo como o melhor intérprete da vida nativa em oposição ao viajante, e especialmente ao missionário e ao administrador, alguns dos quais haviam estado no campo por muito mais tempo e possuíam melhores contatos e mais habilidade na língua nativa. Durante a década de 20, Clifford afirma que Malinowski desempenhou um papel central na legitimação do pesquisador de campo, inclusive com ataques à competência de seus competidores. O teóricopesquisador de campo iria substituir uma divisão mais antiga entre o "man on the

\footnotetext{
${ }^{72}$ Segundo Héilo Silva (2009), uma etnografia só tem três fases na operação analítica que orienta a redação do projeto e do relatório final. A vivência do etnógrafo, porém, converte tais fases em atividades sincrônicas (andar, ver e escrever). Somente essa linha aglutinadora do material colhido, o relato de um percurso, poderá torná-lo legível. Dados e informações sobre a sociedade observada - segundo o autor - devem estar organizados no texto ao longo de uma espinha dorsal, o percurso do etnógrafo. Trata-se de pensar a etnografia como o relato de uma experiência conflituosa de um observador.
} 
spot" (nas palavras de James Frazer) e o sociólogo ou antropólogo na metrópole. Antes do scholar treinado na universidade, testando e fazendo teoria a partir de pesquisa de primeira mão, prevalecia uma economia bem diferente do conhecimento etnográfico. O etnógrafo e o antropólogo, aquele que descrevia e traduzia os costumes e aquele que era o construtor de teorias gerais sobre a humanidade, eram personagens distintos. "Malinowski nos dá a imagem do novo "antropólogo": acocorando-se junto à fogueira; olhando, ouvindo e perguntando; registrando e interpretando a vida trobriandesa" (Clifford, 1998:26). O novo teórico-pesquisador de campo, como mostram as notas de Malinowski para a introdução de Os Argonautas, estava muito preocupado com o problema retórico de convencer seus leitores de que os fatos que estava colocando diante deles eram objetivamente adquiridos, não criações subjetivas. $O$ frontispício de Os Argonautas, por exemplo, como toda fotografia, afirma a presença da cena diante das lentes e sugere também a presença do etnógrafo elaborando ativamente esse fragmento da realidade ${ }^{73}$. Segundo Clifford, o modo predominante e moderno de autoridade no trabalho de campo é assim expresso: "Você está lá... porque eu estava lá" (Clifford, 1998:18)"

Robert Park, que foi repórter e editor de vários jornais norte americanos, afirmava que o sociólogo seria "uma espécie de super repórter" que informa de maneira um pouco mais precisa e com um pouco mais de distância que a média.

\footnotetext{
${ }^{73}$ Sobre os usos da fotografia na obra etnográfica de Bronislaw Malinowski ver Samain, Ettiene. "Ver" e "dizer" na tradição etnográfica: Bronislaw Malinowski e a fotografia. Horizontes Antropológicos, Porto Alegre, ano 1, n. 2, p. 23-60, jul./set. 1995. Segundo o autor, o nascimento da fotografia se dá na mesma época que da antropologia. A eclosão conjunta - em meados do século XIX - desses dois suportes, teria uma vocação comum: a de tentar revelar os homens e as sociedades, suas paixões, seus delírios, seus imaginários. Especificamente sobre Malinowski, chama a atenção o uso crescente que ele faz da fotografia. 0 texto dos Argonautas incorpora 65 pranchas (totalizando 75 fotografias). São 92 na Vida Sexual dos Selvagens e chegarão a 116 nos Jardins de Coral. Um total de 283 fotografias espalhadas ao longo das 1883 páginas dessas três obras complementares. Uma relação aproximativa e média de uma fotografia a menos de cada sete páginas de texto escrito deixando de lado outras numerosas figuras, plantas, mapas e diagramas, associados aos mesmos textos. É muito. Considerável até, se levarmos em conta a época (1914-18), as condições precárias de preparação das placas sensíveis, o arsenal necessário à revelação das chapas e dos filmes e a inexperiência profissional do próprio Malinowski.

74 Segundo Clifford, em anos recentes, tem havido um notável deslocamento de ênfase da experiência para a interpretação. A interpretação, baseada num modelo filológico de "leitura textual", surge como uma alternativa sofisticada às afirmações hoje aparentemente ingênuas de autoridade experiencial (1998:39). A antropologia interpretativa poderia desmistificar muito do que anteriormente passara sem questionamento na construção de narrativas, tipos, observações e descrições etnográficas.
} 
Suas pesquisas e sondagens sociológicas não seriam mais que "formas superiores de jornalismo". Sem comprar a afirmação exagerada - e notadamente antipática à academia - de Park, pode-se concordar que a sociologia e a etnografia - como também a crítica literária - concorreram para a constituição da reportagem, mesmo que tivessem cada uma delas destinatários e objetivos distintos. Tendo como leitores outros etnógrafos e suas análises críticas, o etnógrafo buscou a predominância da descrição densa sobre a narração, criou modelos interpretativos sobre a vida de grupos observados e imaginou as particularidades de tais grupos diante de outros. Já os repórteres buscaram explicitamente na narração o modelo sob o qual reproduzir a sua experiência de campo. Submetidos ao crivo dos leitores, criaram a reportagem; uma narrativa eminentemente urbana que tem no drama da novidade o seu leitmotiv.

A emergência de um Rio de Janeiro moderno, no início do século XX, já contará com a experiência "de campo" dos repórteres - que como turistas profissionais já haviam vencido distâncias atrás de notícias. Para traduzir em factuais reportagens a nova ambiência urbana, o grupo de repórteres que participará da transição para o jornalismo moderno fará uso de métodos associados à prática etnográfica como a coleta de dados e a observação participante. Preocupados em captar a alma, as formas de socialização, do ambiente urbano, repórteres como João do Rio e Irineu Marinho - à maneira dos sociólogos ligados às teorias da interação - farão do território carioca o seu campo de investigação da vida em sociedade. 


\section{4}

Da redação às ruas: em busca da alma da cidade

Oh! sim, as ruas têm alma!

João do Rio. A alma encantadora das ruas.

A rua! Que é a rua? João do Rio conta que procurou nos dicionários a definição e para eles a rua não passaria de um alinhado de fachadas por onde se anda nas povoações. Ora - argumenta o repórter - a rua é mais do que isso, "a rua é um fator da vida das cidades, a rua tem alma"! Olhando para cada casa, cada avenida, que então se erguia na capital da República, João do Rio enxergou o esforço exaustivo dos trabalhadores braçais; "há suor humano na argamassa do seu calçamento". Narrador atento às mudanças materiais, às transfigurações da forma da cidade moderna, foi, no entanto, ao captar a alma do Rio de Janeiro, que João viu adicionado ao seu o nome da sua cidade. Antes mesmo do final do século XIX, a perspectiva que alçaria João do Rio à condição de destacado intérprete da nova realidade urbana já se fazia notar na atividade de um literato, que mesmo convivendo com uma cena literária onde o realismo já estava presente, afirma logo de saída que o seu relato não se atem a realidade dos fatos. Manuel Joaquim de Macedo nas memórias que escreve sobre a Rua do Ouvidor - publicadas no Jornal do Commercio, no final do XIX - diz não vender gato por lebre, pois jamais garantiu serem verdadeiras as suas afirmações ${ }^{75}$. Com o intuito de compreender a rua que, mais do que logradouro, seria uma imagem na qual os cariocas se reconheciam, o escritor afirma que não estando preso a realidade dos

75 MACEDO, Joaquim Manuel de. Memórias da Rua do Ouvidor. Rio de Janeiro: Typographia Perseverança, 1878. Pg. 56. "Referindo no capítulo antecedente a tradição de Perpétua Mineira, declarei positivamente que eu a encontrara completada nos meus velhos manuscritos, como estes, porém, não trazem nome de autor, nem baseiam em documentos suas informações, é claro que só me aproveitam para enfeitar estas Memórias; porque fora abuso condenável exporme a falsificar a história, dando por fatos averiguados alguns devaneios de imaginação. Podem severos críticos achar de mau gosto o meu repetido recurso aos velhos manuscritos, mas hei de teimar nele: escrevo as Memórias da Rua do Ouvidor; que em seu caráter de rua das modas, da elegância e do luxo merece e deve ser adornada e adereçada condignamente. Não vendo gato por lebre, desde que previamente declaro a origem e a natureza das tradições, que vou contando a salvar sempre a verdade histórica". Disponível em: http://mww.dominiopublico.gov.br/pesquisa/DetalheObraForm.do?select_action=\&co_obra=7544 
fatos - o que para ele não diminuía o valor do relato - pôde traduzir melhor a Rua do Ouvidor. Macedo não quis apenas observar e contar a Ouvidor, mas sim entender a sua alma, descobrir seu sentido. O gênero que, no início do século XX, iria traduzir a sociabilidade dos citadinos, suas formas de interação, não seria mais o mobilizado por Manuel Joaquim de Macedo. A reportagem, com seu texto ágil, curto e prenhe de novidades, será a língua franca através da qual a alma da cidade moderna será lida.

O sociólogo francês Isaac Joseph afirma que a cidade democrática, cenário de interação de estrangeiros - como havia sugerido Simmel - não tem relações comuns pré-estabelecidas. Por esse motivo, a teoria da estruturação não estaria habilitada a captar tudo o que a cidade moderna é. A sociologia da interação sim, seria mais capaz de interpretar essa dinâmica. O dilema do estrangeiro, "como se dará a interação?", que denota um pertencimento social indeterminado, é o dilema de todo habitante da cidade moderna ${ }^{76}$. O estrangeiro como figura e não mais apenas como objeto empírico - como nos primeiros anos da Escola de Chicago e no próprio pensamento de Simmel - interage no espaço urbano a partir de reflexões, da expectativa de alianças, que iguala todo ser urbano na condição de estranho. Segundo Joseph, a força do legado de Chicago para nós, hoje, estaria em inverter completamente a problemática da integração, isto é, não preocupar-se em saber como o estrangeiro se torna "igual a todo o mundo", mas considerá-lo com o qualquer um, como um observador do vínculo social comum (Valladares; Lima, 2000). Autores mais ligados à interação do que à estruturação poderiam, portanto - segundo o autor - traduzir melhor essa cidade de estrangeiros. Não é aleatório o fato dessa perspectiva sociológica - que tem sua origem nas reflexões

\footnotetext{
76 "Ora, de Simmel a Goffman, a linha de pensamento que incorporou a questão do estrangeiro construiu-se sobre outra experiência: a dos vínculos fracos, a do mal-entendido e do retraimento, da inevitável superficialidade das trocas. De fato, como é possível pensar uma "comunidade de exaltação recíproca" com aquele que não se conhece e não se vai conhecer? Como não perceber que o que é comum, o que prevalece é, ao contrário, a inquietação da reciprocidade, a frieza da relação? Relação que não tem como apelar para o implícito nem para a familiaridade. 0 que interessa à tradição sociológica que tem origem em Chicago não é a sociabilidade de um "nós" já constituído. $O$ interessante é o que emerge de um encontro público [...], o mais sociedade, para falar como Simmel, que se pode esperar de uma reunião feliz, pertinente". In. VALLADARES, Lícia do Prado; LIMA, Roberto Kant. A Escola de Chicago: entrevista com Isaac Joseph. BIB, Rio de Janeiro, n. $^{\circ} 49,1^{\circ}$ semestre de 2000, pp. 3-13.
} 
de Georg Simmel e forma Escola, como comentado por Howard Becker ${ }^{77}$, em Chicago - coincidir cronologicamente com o olhar desenvolvido pela nova imprensa. Sociabilidade, interação e indiferença no ambiente urbano são objetos de ambos grupos de observadores que, ao lidarem com a cidade moderna, estão também conquistando terreno para a institucionalização de seus respectivos campos de atuação.

Maria Alice Rezende de Carvalho (2012) conta que quando o repórter Irineu Marinho resolveu criar um novo jornal - moderno, lucrativo e popular - um dos profissionais que primeiro lhe ocorreu convidar para participar do empreendimento foi João do Rio, que vinha, segundo a autora, exercitando um jeito peculiar de escrever sobre a cidade e seus personagens. Esses dois repórteres não levaram adiante a sociedade - Irineu Marinho seguiria com outros companheiros o caminho que já havia traçado em sua cabeça -, mas ambos personagens mantiveram em comum a forma de olhar para a cidade e a capacidade de identificar-se com o seu público. Segundo a autora, belle époque e Zé-Povo seriam duas faces do mesmo fenômeno de modernização do Rio de Janeiro. O tom da Gazeta de Notícias - jornal que abrigou João do Rio e Irineu Marinho, como também Olavo Bilac - privilegiará a primeira, já A Noite fará o registro do conflito, dos desajustes do moderno tal como eram sentidos pelo Zé Povo, sendo esse afinal o foco de Irineu Marinho, que irá conformar, pouco a pouco, uma fronteira sutil entre ele e a Gazeta de Notícias ${ }^{78}$. Segundo Maria

\footnotetext{
77 “Vejamos, então, em poucas palavras, o que me parece ser esse nosso modo de pensar. [...] Uma das ideias certamente predominantes referia-se à oposição a noções como as de organização social e estrutura social, muito comuns no pensamento dos egressos de Harvard ou Columbia, entre os alunos de Robert Merton, Talcott Parsons, bem como no pensamento de certos antropólogos ingleses, que usavam a metáfora da estrutura social de modo excessivamente reificado. Penso que para nós, ao contrário, uma das ideias mais importantes era a de que a organização social consiste apenas em pessoas que fazem as mesmas coisas juntas, de maneira muito semelhante, durante muito tempo. Ou seja, para nós a unidade básica de estudo era a interação social, pessoas que se reúnem para fazer coisas em comum - exemplificando com um tema antropológico, para constituir uma família, para criar um sistema de parentesco. [...] Nesse sentido, a Escola tornou-se uma espécie de perspectiva ou opinião global, e eu não sei muito bem se seria honroso chamar essa perspectiva de teoria, ou se seria embaraçoso considerá-la assim, porque na verdade ela é um modo de pensar, uma maneira de abordar problemas de pesquisa que estão muito vivos e presentes em boa parte do trabalho feito hoje em dia". BECKER, Howard. Conferência A Escola de Chicago. MANA 2(2):177-188, 1996.
}

\footnotetext{
${ }^{78}$ De Paris, em carta ao sócio e amigo Antonio Leal da Costa, Irineu Marinho escreve em 1924: “E se ocorresse qualquer reportagem das que fazíamos antigamente e das quais o Zé-Povo tanto gosta? Alguma coisa de rua, que interessasse a toda a gente e que não ofendesse a ninguém? Eu
} 
Alice, o dado que melhor traduz a intenção de Irineu Marinho de distinguir A Noite dos demais jornais foi o destaque que conferiu às charges e caricaturas, contratando para isso, o mais importante time de artistas da época (2012:107). Com dois grandes eixos de organização das suas pautas: o cotidiano da cidade e a política em todos os níveis, com ênfase no nacional, o jornal abordará, no que se refere à cidade, não somente temas como a abertura de ruas, canalização de rios, iluminação pública, como também "aqueles mais propriamente recobertos pela noção de ethos urbano, isto é, o modo de vida dos citadinos: a "fezinha" nos jogos de azar, a paciência diante de epidemias ou enchentes, a entrega absoluta aos festejos de Momo" (2012:109).

Pierre Bourdieu, em artigo que trata do campo político, fala sobre situações de "mudanças de paradigmas" dentro de campos específicos nas quais novos ingressantes mudam de tal maneira os princípios de pertencimento ao campo que pessoas que antes faziam parte dele a partir de então não fazem mais, são desqualificadas, e pessoas que dele não faziam parte dali em diante fazem. $\mathrm{O}$ sociólogo francês cita a revolução impressionista como exemplo de situação na qual "os detentores da norma, do nomos, da lei fundamental, encontram-se bruscamente desqualificados, ao passo que os heréticos, ao contrário, são consagrados, canonizados" $" 79$. No Rio de Janeiro do início do século XX, o campo jornalístico passou por situação análoga. A imprensa popular e moderna que surgia junto com o Rio de Janeiro moderno, se não criou um novo campo, alterou profundamente as relações de força vigentes no universo jornalístico da cidade. A figura do repórter e a sua compreensão de jornalismo e de cidade será aquela a nortear, dali em diante, o campo jornalístico que se constituía no país. Maria Alice destaca a insistência de Irineu Marinho em se tornar um repórter e a valorização que ele emprestou a esse personagem. Segundo a autora, essa forma de se inscrever no universo jornalístico adotada por Irineu e pelos demais jovens que acorreram àquele posto, se no início foi uma forma subordinada de inscrição, rapidamente se mostrou ser o modo mais eficaz de adequar a imprensa às novas características da sociedade e também de garantir para essa nova categoria

bato ainda nessa velha tecla porque é a única que não nega fogo". [grifo meu]. Carvalho, Maria Alice Rezende de. Irineu Marinho: imprensa e cidade. Op. cit. Pg. 79.

${ }^{79}$ BOURDIEU, Pierre. O campo político. Rev. Bras. Ciênc. Polít. № 5, Brasília. Jan./Jul 2011. 
profissional a liderança na renovação do jornalismo. Os "artigos de fundo" do jornalismo oitocentista foram sendo substituídos por um formato noticioso de jornalismo e, como nos conta Maria Alice, o sucesso do empreendimento do jovem repórter Irineu Marinho se deu pela percepção dessa mudança.

Os literatos que, até então, davam o tom das redações tinham nos jornais uma fonte auxiliar de ganho, mas sua identidade e as formas de consagração a que estavam submetidos não derivavam da rede de produção e circulação de notícias. Para Irineu e o novo contingente de repórteres, ao contrário, estava claro que não havia alternativa de ganho ou possibilidade de consagração que não viesse do consumo de notícias na capital federal. (CARVALHO, 2012:89)

O jornal A Noite, que de início foi um empreendimento sem muito lastro econômico, rapidamente se tornou um sucesso de vendas. Compreendendo a circunstância do Rio de Janeiro de então - uma sociedade em trânsito, pouco instruída, porém aberta a novidades -, A Noite oferecia aos seus leitores notícias curtas, facilmente assimiláveis, passíveis de transmissão oral, capazes de animar interações e promover acordos entre grupos sem muita prática de negociação. Conforme a autora, em cidades como o Rio de Janeiro - com um porto com volume considerável de viajantes e de transações comerciais - notícias curtas de jornais são um produto cultural de máxima importância ${ }^{80}$. Maria Alice destaca o agenciamento dos debates públicos que tinham curso na capital federal, afirmando que A Noite fazia orbitar à sua volta um público bem maior do que aquele constituído exclusivamente por leitores - como, por exemplo, no já citado caso da roleta da Carioca. Segundo a socióloga, o jornal de Irineu Marinho tangenciou dessa forma um dos principais problemas das cidades modernas, o da sua integração sociocultural.

Sem que isso fosse sua atribuição, pois a questão da segmentação urbana possui múltiplas e complexas determinações, impossíveis de serem sanadas por um jornal, percebe-se que A Noite constituiu, com reportagens fotográficas, charges e textos ágeis, uma espécie de "língua franca", capaz de atenuar fronteiras sociais e intelectuais da cidade. Foi o jornal dos cariocas - já o disse Nelson Rodrigues -, cortando transversalmente os diferentes públicos da capital federal. (CARVALHO, 2012:151)

\footnotetext{
${ }^{80}$ [...] Assim, entre estrangeiros e nacionais semiletrados, a conversa envolvendo os fait divers seria um modo de difusão de notícias - primeiro o crime ou o sobrenatural, mas, logo, o comércio, a oferta de trabalho, as sociedades por ações, as fusões, as falências e todos os atos descontínuos de uma "guerra civil" que se desenrolava no país [...]. Carvalho, Maria Alice Rezende de. Irineu Marinho: imprensa e cidade. Op. cit. Pg. 88
} 
A autora fala que se até os anos de 1910 a comunicação entre os artistas do mundo popular e o conjunto da cidade era informal e descontínua, sustentada em personalidades isoladas, dentre as quais Ernesto Nazareth ou Chiquinha Gonzaga, a partir da atuação de jornalistas, repórteres e cronistas, se desenvolveram elos mais consistentes entre os diferentes grupos e classes sociais da cidade. Para integrar a cidade dessa maneira, essa nova imprensa - caracterizada aqui através do periódico de Irineu Marinho e da obra de Paulo Barreto - precisou compreender a especificidade dos novos tempos que sacudiam a capital federal. Cidade moderna e imprensa moderna - fenômenos de um mesmo processo que levou grandes massas iletradas às cidades - têm profundas conexões entre si. A construção da sensibilidade moderna, a intensificação da vida nervosa que, segundo Simmel $^{81}$, resulta da mudança rápida e ininterrupta de impressões interiores e exteriores também contou com a atuação dessa imprensa moderna e popular. Maria Alice conta que no início do século XX, a "imprensa popular" e o "cinema de mistério" foram formas conjugadas de condicionar sensorialmente o leitor-espectador, extraindo-o do conforto físico e mental a que estava habituado nas pequenas cidades para adaptá-lo à vida nas metrópoles. Segundo a autora, essas duas mídias contribuiriam na difusão de "uma nova estética de excitação"

Compreendendo a entorse mental pela qual passou aquela sociedade, captando o ritmo e as formas de interação que se davam no ambiente urbano, os repórteres puderam ser atores que promoveram certa integração social - mesmo naquela cidade tão marcada pelas desigualdades. O desafio político da integração social do espaço urbano, no campo da Sociologia, tem remetido aqueles que se debruçam sobre o tema à experiência da Chicago da virada do século XIX. Albion

\footnotetext{
81 "Na medida em que a cidade grande cria precisamente estas condições psicológicas - a cada saída à rua, com a velocidade e as variedades da vida econômica, profissional e social -, ela propicia, já nos fundamentos sensíveis da vida anímica, no quantum da consciência que ela nos exige em virtude de nossa organização enquanto seres que operam distinções, uma oposição profunda com relação à cidade pequena e à vida no campo, com ritmo mais lento e mais habitual, que corre mais uniformemente de sua imagem sensível-espiritual de vida." SIMMEL, Georg. As grandes cidades e a vida do espírito (1903). Mana 11.2, 2005: 577-591.

82 "Transformações radicais nas plantas urbanas e na arquitetura, velocidade, iluminação elétrica, barulho de máquinas, estímulos até então pouco conhecidos pela maior parte da população, impunham um aprendizado. Na nova economia perceptiva do indivíduo moderno, as reportagens sobre crimes, acidentes de bonde, atropelamentos e outros fatos da grande cidade encontrarão tradução imagética em filmes produzidos sob a batuta de donos de jornais". Carvalho, Maria Alice Rezende de. Irineu Marinho: imprensa e cidade. Op. cit. Pg. 24
} 
Small foi um dos primeiros professores daquela universidade. Como muitos dos primeiros sociólogos americanos, era pastor protestante, do tipo interessado na reforma social. Segundo Becker (1996), Small estava voltado para o equacionamento dos problemas sociais que afligiam as grandes cidades norteamericanas de então, seu pensamento, assim como o de outras pessoas que trabalhavam com ele, e o de estudantes que foram para Chicago - muitos deles pastores de uma ou outra confissão protestante -, foi muito influenciado pela ideia que tinham do que precisava ser feito, dos problemas com os quais a sociedade se defrontava, do que teria de ser enfrentado. A Escola de Chicago nasce, portanto, com essa missão de reforma, de melhorismo. A forte normatividade marcará a sociologia urbana - bastante intervencionista - praticada nos primeiros anos da Escola. O princípio metodológico mudancista, que não vê revolução no horizonte teórico, mas sim acomodação, no fundo, revela um projeto de ordem urbana.

Como vimos, o jornalismo praticado por A Noite e por João do Rio também estava muito preocupado com a cidade. Nesse período histórico, sociologia ainda em construção, a experiência da Escola de Chicago mostra como a disciplina esteve muito ligada a esse tipo de prática do jornalismo. Conforme Howard Becker, Park teria estudado na Universidade de Harvard e depois em Heidelberg, com Simmel, mas não teria gostado muito da vida acadêmica, ingressando, então, na carreira jornalística. Primeiro foi repórter, depois editor de vários jornais americanos, chegando a ser editor chefe do Free Press de Detroit, o mais influente jornal da cidade. Park trabalhou durante anos nessa profissão, tornando-se, posteriormente, ghost writer de famosos líderes negros da época, como Booker T. Washington. Logo em seus primeiros tempos em Chicago, Park escreveu um ensaio sobre a cidade, encarando-a como um laboratório para a investigação da vida social. Segundo Becker, ele tinha uma ideia central sobre a história do mundo naquela época, sobre o que estava ocorrendo, ideia que resumiu ao dizer: "hoje, o mundo inteiro ou vive na cidade ou está a caminho da cidade; então, se estudarmos as cidades, poderemos compreender o que se passa no mundo" (Becker, 1996:180). Assim, Park teria organizado seus alunos para esse empreendimento.

Segundo Becker, uma das características do pensamento de Robert Park e isso se aplicaria à Escola de Chicago como um todo - era não ser puramente 
qualitativo ou quantitativo. "Park era muito eclético em termos de método". Em certo momento, nos conta Becker, Park defendeu a ideia de que o espaço físico espelhava o espaço social, de modo que se fosse possível medir a distância física entre populações, se saberia algo sobre a distância social entre elas. Tal metáfora levou ao desenvolvimento de uma área chamada ecologia, não no sentido de preservação do meio ambiente, mas a noção de ecologia na forma usada pela biologia vegetal daquela época, e que se referia à competição pelo espaço. A partir dessas questões, Park elaborou noções como a de região moral, a área da cidade onde uma população se separava das demais. Julia O'Donnel em seu trabalho sobre João do Rio, aproxima as elaborações da Escola de Chicago (com ênfase nos estudos de Robert Park) do pensamento do cronista carioca. A antropóloga afirma que a trajetória de Park, fundador da tradição urbanista e empirista da Escola de Chicago, é paradigmática para a compreensão do desenvolvimento da cidade como objeto dos estudos sociais, e também para a interlocução com João do Rio.

Jornalista de profissão, Park manteve na academia a perspectiva e a metodologia adquiridas nas redações que definiriam seu estilo enquanto pesquisador social disposto a decifrar a cidade. "Acostumado a olhar para as ruas como manancial de dados para reportagens, Park passou, como sociólogo, a encarar o universo urbano como habitat do homem criado na sociedade moderno-industrial, o que revela que sua experiência como repórter foi vital à formação de sua sensibilidade etnográfica aplicada às questões urbanas" (O’Donnel, 2007:93). Segundo a autora, a saída às ruas era o maior trunfo de Park enquanto repórter. João do Rio, seu contemporâneo, teria esse mesmo olhar treinado numa mesma matriz metodológica - a caça à notícia - o que resultara em ambos os casos numa reflexão mais ampla acerca das interações humanas no espaço da cidade.

A aproximação que Julia O’Donnel faz de João do Rio aos sociólogos de Chicago é profícua. O olhar que esses observadores lançaram para o meio urbano de fato guardam muitas semelhanças que, obviamente, vão além da coincidência cronológica. A percepção de que as cidades dividem-se em zonas morais, por exemplo, está claramente presente também no repórter carioca. Quando afirma que "nas grandes cidades a rua passa a criar o seu tipo, a plasmar o moral dos 
seus habitantes, a inocular-lhes misteriosamente gostos, costumes, hábitos, modos, opiniões políticas" (Rio, 2013), é impossível não perceber a semelhança do seu discurso, da sua maneira de perceber a cidade com a de Robert Park. Porém, podemos estender essa comparação, essa aproximação, a todo o campo jornalístico que então se estabelecia na cidade do Rio de Janeiro. A experiência de Irineu Marinho e dos repórteres do seu jornal mostram igualmente a aposta desses atores na rua como posto de observação e local de consagração. A própria figura do repórter - que marcará o campo jornalístico acentuando o caráter noticioso da imprensa, afastando-a do linguajar embolado da literatura oitocentista - está ligada a concepções de cidade presentes no pensamento que se desenvolveu em Chicago. O repórter é o personagem por excelência da mobilidade urbana. Ágil, sempre atenta ao drama da novidade, a figura do repórter é a de uma presença ubíqua na cidade.

Como afirma Isaac Joseph, muito influenciado pelo pensamento de Chicago, habitar uma cidade não é apenas ter nela sua residência, mas é mudar de residência, passar de uma para outra, de um lugar para outro, de uma região para outra da cidade. Segundo o francês, Robert Park propunha como definição para segregação: estar cativo em um território, sem possibilidade de frequentar outros. Por isso a importância da temática da acessibilidade urbana na sociologia dos espaços públicos e a importância dos "locais-movimentos da cidade" (estações de trem e rodoviárias, estações de metrô, aeroportos etc. ${ }^{83}$. Pensar a cidade, nessa perspectiva, não seria insistir em apropriar-se ou em querer pertencer a um bairro, mas sim estudar os recursos urbanísticos, os equipamentos e serviços que permitem ao citadino superar o estranhamento de um território pouco familiar e orientar-se em um "universo de estranhos". Será exagero aproximar a essa perspectiva que marcou a Escola de Chicago a atuação desses primeiros repórteres do Rio de Janeiro?

João do Rio e Irineu Marinho, essas duas figuras que vestiram tão bem a roupa de repórteres - cada qual a sua maneira, porém ambos falando a partir das ruas, movimentando-se pela cidade, integrando-a e traduzindo-a nas suas histórias

83 "O citadino é alguém que se locomove, e o movimento é parte fundamental de sua atividade. Isso significa não apenas que a mobilidade dá a medida das relações sociais e o grau de socialização de determinada população urbana, mas também que a urbanidade só se define pela capacidade de compor diversas regiões morais. [...]". Isaac Joseph. In. Valladares; Lima, 2000:7. 
-, tiveram no momento das suas mortes o reconhecimento da cidade. E aqui, quase que não se trata de uma figura de linguagem. A cidade em peso esteve presente no cortejo fúnebre de João do Rio. A capital federal que, àquela altura, tinha aproximadamente um milhão de habitantes, viu cem mil dos seus cidadãos acompanharem o caixão que levava o corpo do jornalista. Da mesma forma, uma multidão se aglomerou no largo da Carioca para prestar homenagem ao repórter que criara o mais querido dentre os jornais do Rio de Janeiro. Segundo Carvalho, "Irineu Marinho morreu como um herói da cidade" (2012:209). O apreço que a cidade demonstrou por esses seus intérpretes revela que a trajetória desses repórteres foi exitosa, que o posto de observação de onde liam a cidade foi capaz de oferecer vias - naquela quadra foi principalmente a da cultura - para atenuar fronteiras sociais e intelectuais da cidade estabelecendo um léxico comum entre os citadinos. Originadas da crise de sociabilidade que a cidade viveu no momento de sua modernização, as imagens que contaram o Rio de Janeiro do início do século XX, hoje parecem parte de uma fase idílica da cidade. A ideia de um Rio de Janeiro que reconhece nas ruas o lugar predileto de sua sociabilidade foi dando lugar à ideia de uma cidade em guerra, partida, e o vazio de solidariedade que se faz enxergar na representação dominante que se tem hoje da cidade, em especial dos seus redutos populares, evidencia que, de novo, vivemos o dilema da integração social. 


\title{
3.
}

\section{Considerações finais}

\section{1.}

\section{A civilização do espetáculo}

\begin{abstract}
A civilização do espetáculo é cruel. Os espectadores não têm memória; por isso também não têm remorsos nem verdadeira consciência. Vivem presos a novidade, não importa qual, contanto que seja nova. Esquecem depressa e passam sem pestanejar das cenas de morte e destruição do Golfo Pérsico às curvas, contorções e trêmulos de Madonna e Michael Jackson. Comandantes e bispos estão fadados a mesma sorte; também eles são aguardados pelo Grande Bocejo, anônimo e universal, que é o Apocalipse e o Juízo Final da sociedade do espetáculo ${ }^{84}$.
\end{abstract}

Octavio Paz, Chiapas: hechos, dichos y gestos.

A civilização do espetáculo é a civilização de um mundo onde o primeiro lugar na tabela de valores vigente é ocupado pelo entretenimento. Assim define Mario Vargas Llosa o mundo contemporâneo. Divertir-se, escapar do tédio, é a paixão universal. "Não se entediar e evitar o que perturba, preocupa e angustia passou a ser, para setores sociais cada vez mais amplos do vértice à base da pirâmide social, o preceito de toda uma geração" (2013:30). Um ideal de vida legítimo, mas que transforma em valor supremo a propensão natural do homem a divertir-se. Das consequências inesperadas, o autor aponta a banalização da cultura, a generalização da frivolidade e, no campo da informação - o que nos interessa diretamente -, a proliferação do jornalismo irresponsável da bisbilhotice e do escândalo.

De que maneira o jornalismo influiu na civilização do espetáculo e esta naquele? Segundo Vargas Llosa, a fronteira que tradicionalmente separava o jornalismo sério do sensacionalista foi perdendo nitidez a tal ponto que em nossos dias seria difícil estabelecer diferença entre os vários meios de informação. Com a

\footnotetext{
${ }^{84}$ PAZ, Octavio. "Chiapas: hechos, dichos y gestos". Obra completa, V, 2a edição, Barcelona: Galáxia Gutenberg / Circulo de lectores, 2002. Pg. 546. Apud. VARGAS LLOSA, Mario. A civilização do espetáculo: uma radiografia do nosso tempo e da nossa cultura. Tradução Ivone Benedetti. 1a edição. Rio de Janeiro: Objetiva, 2013.
} 
transformação do entretenimento e da diversão em valor supremo de uma época, alteraram-se as prioridades também no campo da informação. As notícias passaram a ser importantes ou secundárias, sobretudo, por seu caráter novidadeiro, surpreendente, insólito, escandaloso e espetacular. Sem que isso tenha sido proposto, o jornalismo de nossos dias, acompanhando o preceito cultural imperante e deformando seus objetivos tradicionais, procurou - nas palavras do escritor - entreter e divertir informando (2013:47). Transformando informação em instrumento de diversão, esse jornalismo foi abrindo aos poucos as portas da legitimidade para aquilo que, segundo Vargas Llosa, antes, se confinava num jornalismo marginal: escândalo, deslealdade, bisbilhotice, violação da privacidade, quando não - em casos piores - difamações, calúnias e notícias infundadas. O literato afirma não ser exagerado dizer que a revista Hola! (publicação espanhola sobre o mundo das celebridades) e seus congêneres sejam os produtos jornalísticos mais genuínos da civilização do espetáculo. Atestaria essa afirmação o fato de que essas revistas caminham na contra mão das empresas jornalísticas que assistem, dia a dia, suas vendas minguarem.

O sucesso desse jornalismo de espetáculo se dá - segundo Vargas Llosa por não existir forma mais eficaz de entreter e divertir do que alimentar as paixões baixas dos homens. O alimento mórbido, exigido e reivindicado pela fome de espanto, pressiona os meios de comunicação por parte do público, sendo difícil mesmo para a imprensa mais responsável evitar que suas páginas se tinjam de sangue. $\mathrm{O}$ escritor adverte que toda generalização é falaciosa, e não se pode pôr todos igualmente no mesmo saco. Evidentemente, há diferenças, e alguns meios de comunicação tentam resistir à pressão sob a qual atuam, sem renunciar aos velhos paradigmas de seriedade, objetividade, rigor e fidelidade à verdade, embora isso seja enfadonho e provoque nos leitores e ouvintes o Grande Bocejo de que falava Octavio Paz (2013:50). A tendência que, a seu ver, marca o fazer jornalístico de nosso tempo é a ligada ao espetáculo. E aqueles que não rezarem nesse altar correm o risco de ficar falando para fantasmas.

Vargas Llosa afirma que nenhum jornal, revista e noticiário de hoje poderá sobreviver - conservar um público fiel - se desobedecer cabalmente às características distintivas da cultura predominante da sociedade e do tempo em que atua. Não estaria em poder do jornalismo por si só mudar a civilização do 
espetáculo, que ele contribuiu para forjar. Atuando conforme os preceitos do espetáculo em resposta a uma exigência de seu público, os jornais contribuíram mais que ninguém para consolidar essa civilização light que deu à frivolidade a supremacia que antes tiveram as ideias e as realizações artísticas (2013:48). Diz o escritor não ser estranho que a literatura mais representativa de nossa época seja a literatura $l i g h t^{85}$, ligeira, fácil, uma literatura que, sem o menor rubor, se propõe acima de tudo a divertir.

Desse diagnóstico crítico acerca dos nossos tempos, uma das características mais dramáticas seria o empobrecimento das ideias como força motriz da vida cultural. A entrega submissa a emoções e sensações teria nos levado a um embotamento da sensibilidade e do intelecto. A razão para a perda total do interesse do conjunto da sociedade pelos intelectuais seria a consequência direta do ínfimo valor que o pensamento tem na civilização do espetáculo. O desaparecimento do intelectual dos debates públicos e sua substituição pelas celebridades, como afirma Vargas Llosa, se deve a uma cultura que propicia o menor esforço intelectual, a ausência de preocupação, angústias e, em última instância, de pensamento. $\mathrm{O}$ intelectual que legitimava as nossas ideias sobre o mundo, representava essas ideias, foi substituído pelo império da comunicação que dá passagem a multiplicidade de perspectivas, definições e concepções diversas sobre todas as coisas. Sem a preocupação em ganhar a opinião de modo definitivo, a comunicação e a ideia de entretenimento são, no mundo contemporâneo, forças muito mais poderosas e ativas do que a reflexão e a vida intelectual. A reportagem - que desde a sua origem tem sido uma espécie de ficcionalização da realidade - vê reforçado, contemporaneamente, esse seu traço constitutivo através da ideia de entretenimento. Para contar o drama da novidade o repórter precisa prender a atenção do leitor. E ele só consegue interessar o público se tiver algo que o deleite, faça sorrir, que mexa com sua emoção.

Não se pode negar que esse é um fenômeno constitutivo do jornalismo moderno. O jornal que se tornou independente foi feito para vender e para isso ele apostou nas emoções. Na busca por liberdade editorial e independência para seus

\footnotetext{
${ }^{85}$ Para sobreviver a literatura se tornou light, termo que segundo Vargas Llosa não deve ser traduzido por leve, pois, na verdade, "quer dizer irresponsável e, frequentemente, idiota". (2013:196).
} 
posicionamentos políticos, a imprensa moderna dependente da aprovação do público se viu enredada por outra força a conformar a sua voz. Para obter sucesso de mercado, a imprensa teve de submeter-se à pressão das expectativas e das exigências da maioria. Essa política da simplificação demagógica - em tudo oposta à intenção democrática de informar, ou de educar divertindo - não pode ser justificada, como afirma Bourdieu, pelas expectativas do público. Pois os jornalistas não fazem mais que projetar sobre ele suas próprias inclinações, sua própria visão de mundo. "Especialmente quando o medo de entediar os leva a dar prioridade ao combate sobre o debate, à polêmica sobre a dialética” (1997:134).

Em a "Influência do jornalismo" (1997), Pierre Bourdieu examina como a restrição estrutural exercida pelo campo jornalístico, ele próprio dominado pelas pressões do mercado, modifica mais ou menos profundamente as relações de força no interior de diferentes campos. Para o autor, os mecanismos de que o campo jornalístico é o lugar e os efeitos que ele exerce sobre os outros campos são determinados em sua intensidade e sua orientação pela estrutura que o caracteriza. A análise de Bourdieu sobre o campo jornalístico ${ }^{86}$ abandona a explicação corrente de que uma determinada ideologia dos dirigentes dos meios de comunicação seria a principal responsável pelo que é produzido pela imprensa. Ao contrário, o autor procura mostrar as diversas variáveis que influenciam o campo jornalístico e os elementos e regras próprios a esse meio profissional, que funcionam como uma espécie de auto censura invisível.

Para Bourdieu, existem restrições externas (pressão econômica e preocupação com os índices de audiência) e internas (necessidade de reconhecimento dos jornalistas por seus pares, submissão ao tempo de realização das matérias e busca incessante pelo furo de reportagem) que fazem com que ocorra uma produção de informações e abordagens homogêneas e virtualmente

${ }^{86} \mathrm{O}$ mundo social, para Pierre Bourdieu, deve ser compreendido à luz de dois conceitos fundamentais: campo e habitus. Sua teoria sociológica está apoiada na ideia de que nem o indivíduo nem a estrutura social se tomados isoladamente são suficientes para explicar a sociedade e os fenômenos que nela ocorrem. O habitus consiste em uma matriz geradora de comportamentos, visões de mundo e sistemas de classificação da realidade que se incorporam aos indivíduos, ao mesmo tempo em que se desenvolvem neles. Desse modo, o habitus é apreendido e gerado na sociedade e incorporado pelos indivíduos. Em decorrência desse caráter flexível e relacional, o conceito de habitus somente pode ser entendido com o seu par epistemológico: o conceito de campo. Esse conceito complementa o de habitus, consistindo no espaço em que ocorrem as relações entre os indivíduos, grupos e estruturas sociais, com uma dinâmica que obedece a leis próprias, animadas sempre pelas disputas ocorridas em seu interior. 
despolitizadas. Segundo o autor, por causa das restrições próprias do campo jornalístico a cobertura mediática muitas vezes entra em um círculo vicioso que tende a reforçar ou a fazer ressurgirem os estereótipos sobre violência, periferias, áreas perigosas, etc. A concorrência - que tende a colocar toda a prática jornalística sob o signo da velocidade e da renovação permanente - impõe os assuntos aos jornalistas e frequentemente leva a uma cobertura espetacularizada do acontecido. A concorrência, longe de ser automaticamente geradora de originalidade e de diversidade, tende muitas vezes a favorecer a uniformidade da oferta de notícias. Patrick Champagne (1997), o mais destacado dos discípulos de Bourdieu, ao comentar a cobertura da imprensa francesa de eventos violentos nos subúrbios de Paris, destaca o poder da imprensa em reforçar preconceitos.

"Longe de ajudar os habitantes desses subúrbios, a mídia contribui, paradoxalmente, para a sua estigmatização. [...] Esses bairros são apresentados como insalubres e sinistros, e seus moradores como delinquentes. Os jovens que procuram trabalho não têm mais coragem de dizer que moram nesses conjuntos daí para frente mal afamados porque foram manchete na mídia. [...] Esta estigmatização, que é, sem dúvida, involuntária e resulta do próprio campo jornalístico, se estende muito além dos acontecimentos que a provocam e marca essas pessoas mesmo quando elas estão fora de seus bairros."(CHAMPAGNE, 1997:73).

Conforme o autor, a mídia fabrica coletivamente uma representação social que, mesmo quando está muito afastada da realidade, perdura apesar dos desmentidos ou das retificações posteriores porque ela nada mais faz, na maioria das vezes, que reforçar as interpretações espontâneas e mobilizar os prejulgamentos do público. A mídia faz parte integrante da realidade ou, como afirma Champagne, produz efeitos de realidade criando uma visão mediática da realidade que contribui para criar a realidade que ela pretende descrever. Sobretudo a temática da violência e da criminalidade ao exprimir-se mediaticamente passa a ter uma existência publicamente reconhecida e ser levada em conta pelo poder político. A violência sensacionalista que, na maioria das vezes, vira reportagem e manchete nos jornais oculta o problema estrutural que a causou. O olhar do repórter, daquele que está atrás da notícia, que deseja o furo de reportagem, como não podia deixar de ser, está mais voltado para os confrontos do que para a situação objetiva que os provocou. A ausência de interesse pelas mudanças imperceptíveis no instante, que revelam plenamente seus efeitos apenas 
com o tempo, condena repórteres a produzirem uma representação instantaneísta e descontinuísta do mundo. A esse respeito, Bourdieu afirma o seguinte:

"A lógica do campo jornalístico que, sobretudo através da forma particular de que aí se reveste a concorrência e através das rotinas e dos hábitos de pensamento que ele impõe sem discussão, produz uma representação do mundo prenhe de uma filosofia da história como sucessão absurda de desastres sobre os quais não se pode nada. Esse mundo cheio de guerras étnicas e de ódios racistas, de violência e de crime, não é mais que um contexto de ameaças incompreensível e inquietante do qual é preciso antes de tudo se retirar e se proteger." (BOURDIEU, 1997:141).

Segundo Bourdieu, essa visão des-historicizada e des-historicizante, atomizada e atomizante, encontra sua realização paradigmática na imagem que dão do mundo as atualidades televisivas. Uma sucessão de histórias absurdas que acabam todas por assemelhar-se, sequências de acontecimentos que, surgidos sem explicação, desaparecerão sem solução. Esse não é um problema exclusivo da imprensa francesa ou da brasileira. Trata-se de dinâmica mundial, na qual a comunicação prevalece sobre a reflexão ${ }^{87}$. Hoje vivemos a primazia das imagens sobre as ideias (Vargas Llosa, 2013:40). Mas as imagens com as quais convivemos hoje não são frutos nem da reflexão, nem da observação - como a que nos deram os primeiros repórteres ao traduzirem a ambiência das ruas, lugar de onde falavam e obtinham sua legitimidade. O princípio de seleção dos profissionais de imprensa coloca acima da produção de uma imagem densa, que possa servir às novas práticas do mundo, a busca pelo sensacional, pelo espetacular. Ora, nos alerta Bourdieu, quando se faz sociologia, aprende-se que homens e mulheres têm sua responsabilidade, mas que eles ou elas são em grande parte definidos em suas possibilidades e suas impossibilidades pela estrutura na qual estão situados e pela posição que ocupam nessa estrutura (1997:77).

Observa-se hoje que as sanções internas tendem a perder sua força simbólica e que os jornalistas e jornais, mesmo aqueles comprometidos com ideais de objetividade e isenção, perdem sua aura e são, eles próprios, obrigados a

\footnotetext{
87 “O problema maior da comunicação é de saber se as condições de recepção são preenchidas; aquele que escuta tem o código para decodificar o que estou dizendo? [...] A comunicação é instantânea porque, em certo sentido, ela não existe. Ou é apenas aparente. A troca de lugares comuns é uma comunicação sem outro conteúdo que não o fato mesmo da comunicação. [...] Ao contrário, o pensamento é, por definição, subversivo: deve começar por desmontar as ideias feitas e deve em seguida demonstrar." BOURDIEU, Pierre. Sobre a televisão - seguido de: A influência do jornalismo, e, Os Jogos Olímpicos. Tradução Maria Lucia Machado. Rio de Janeiro: Jorge Zahar Ed., 1997. Pg. 41.
} 
fazer concessões à lógica do mercado. Um novo princípio de legitimidade introduzido pela influência da televisão comercial, a consagração pelo número e pela "visibilidade na mídia", tem sido capaz de conferir um substituto aparentemente democrático das sanções específicas impostas pelos campos especializados (1997:109). Em um universo dominado pelo temor de ser entediante e pela preocupação de divertir a qualquer preço, a tendência que se observa por toda parte, seria segundo Bourdieu, a de "sacrificar cada vez mais o editorialista e o repórter-investigador em favor do animador-comunicador, a informação, análise, entrevista aprofundada, discussão de conhecedores ou reportagem em favor do puro divertimento e, em particular, das tagarelices insignificantes dos talk shows”. (1997:133)

Os "óculos" especiais a partir dos quais jornalistas veem certas coisas e não outras operam uma seleção e uma construção do que é selecionado (1997:25). Jornalistas - e aqui evidentemente incluem-se os repórteres - interessam-se pelo excepcional, pelo extraordinário e oferecer cotidianamente o que não é ordinário não é fácil. Através dessa maneira mais do que interessada, enviesada, de evocar o extraordinário, os profissionais de mídia criam o que Bourdieu chama de efeito de real; a simples narração, o fato de relatar como repórter, implica uma construção social da realidade capaz de exercer efeitos sociais de mobilização (ou de desmobilização) (1997:28). Não é de hoje que a imprensa é tida como ator fundamental na tarefa de aproximar os homens e mobilizá-los para tarefas conjuntas. Tocqueville, olhando para a jovem democracia norte americana, chama a atenção para a importância dos jornais na convocação à ação comum dos integrantes de uma sociedade democrática - entendida à maneira do autor como uma sociedade de iguais. Tocqueville não era nenhum admirador ingênuo da sociedade americana. No fundo, ele conservava a hierarquia de valores da classe a que pertencia, a aristocracia francesa. Quando fala sobre a liberdade de imprensa, que lhe parece ter muitos inconvenientes, pois os jornais tenderiam a cometer abusos, sendo difícil evitar que degenerassem em licenciosidade, o pensador francês afirma que seria melhor a liberdade total dos jornais do que a sua supressão. Pois a imprensa seria um guia e um meio para os homens de uma 
sociedade democrática colocarem em prática seus projetos comuns ${ }^{88}$. Somente um jornal seria capaz de depositar no mesmo momento em mil espíritos um mesmo pensamento.

Mario Vargas Llosa diz que no passado, a cultura foi uma espécie de consciência que impedia as pessoas de darem as costas à realidade nua e crua de seu tempo. Agora, ao contrário, seria um mecanismo que permite ignorar os assuntos problemáticos, que nos distrai do que é sério, "submergindo-nos num momentâneo "paraíso artificial”" (2013:183). Um dos grandes problemas dos sociólogos, alerta Bourdieu, seria o de evitar cair em uma ou outra das duas ilusões simétricas na tentativa de comparar épocas distintas. A ilusão do "nunca visto" e a do "sempre assim" é um risco sempre muito grande quando se constrói essas aproximações temporais. O sociólogo pode se enganar e descrever o banal como algo inaudito, simplesmente por incultura (1997:61). Segundo o pensador francês, é preciso evitar ignorar a especificidade da situação atual que, para além das coincidências resultantes do efeito das homologias, apresenta características relativamente sem precedente. Conforme a sua análise, os efeitos que o desenvolvimento da televisão produziu no campo jornalístico e, através dele, em todos os outros campos de produção cultural, são incomparavelmente mais importantes, em sua intensidade e amplitude, que aqueles que o surgimento da literatura industrial, com a grande imprensa e o folhetim, provocou no momento de seu surgimento. (1997:102).

Prevenidos do risco da aproximação entre épocas distantes, podemos afirmar que os intelectuais foram e são ainda hoje criadores de imagens, de imaginações sobre a vida social. A força produtiva das ideias elaboradas sobre a vida em sociedade, como vimos, tem efeito sobre o mundo. Mesmo em um tempo no qual a reflexão foi deslocada em favor do entretenimento, a produção e reprodução de imagens consensuais sobre a vida em conjunto continua tendo força, continua sendo capaz de influir diretamente, ou melhor, materialmente no

88 "Não negarei que, nos povos democráticos, os jornais muitas vezes levam os cidadãos a tomar em comum iniciativas insensatas; mas, se não houvesse jornais, quase não haveria ação comum. O mal que eles produzem é, portanto, bem menor do que o mal que curam. Um jornal não tem por efeito apenas sugerir a um grande número de homens um mesmo projeto; ele lhes fornece os meios de executar em comum os projetos que teriam concebido por conta própria." TOCQUEVILLE, Alexis de. "A democracia na América”. Belo Horizonte, Itatiaia; São Paulo, Editora da Universidade de São Paulo, 597 p., 1998. 
mundo. Porém, quais são as imagens que mobilizamos, nos dias presentes, para falar do Rio de Janeiro? Correndo o risco do pessimismo, pode-se afirmar que a imagem de uma cidade caótica, palco de uma sucessão infinita de barbaridades, é aquela que - estando diariamente nos jornais e telas da cidade - habita a imaginação dos cariocas. A sociabilidade advinda das ruas que informou a construção de uma imagem do Rio de Janeiro pela imprensa, desde o final do século XIX, hoje não existe como outrora. Ao menos não é traduzida pelos jornais como foi um dia. E se tal imagem insiste em se apresentar nos momentos em que se pretende vender a cidade, ela já não conquista o coração dos seus habitantes.

O peculiar dessa imagem malsã que nos traz as reportagens contemporâneas sobre a cidade é que muitas vezes sua origem prescinde aquilo que outrora foi fundamental para o surgimento do próprio "olhar" do repórter: a vivência das ruas, a observação in loco. Se mantém seu caráter literário aproximando-se da literatura pela forma de narrar o drama da novidade, estilizando e ficcionalizando os fatos a despeito do dogma da objetividade -, a reportagem, ao menos a que é nosso objeto de reflexão (a reportagem policial no Rio de Janeiro), parece ter abdicado do seu papel de testemunha ocular dos acontecimentos. Apurando cada vez mais de dentro das redações, consultando nos seus computadores o oráculo contemporâneo que para todas as perguntas tem resposta, repórteres se afastam das ruas e já não tem como captar ou inventar a alma da cidade. Fato análogo é apontado por Mario Vargas Llosa ao receber em Frankfurt o Prêmio da Paz (Friedenspreis) dos editores e livreiros alemães. Embora acredite que a literatura deva comprometer-se com os problemas de seu tempo, o escritor diz que não se pode afirmar que o compromisso cívico e moral do intelectual garanta o acerto na defesa da melhor opção que possa contribuir para a vida em conjunto. Sem renunciar a entreter, a literatura deveria, no entanto, “mergulhar até o pescoço na vida das ruas, na experiência comum, na história em curso, como fez em seus melhores momentos, porque, desse modo, sem arrogância, sem pretender a onisciência, assumindo o risco do erro, o escritor pode prestar um serviço a seus contemporâneos e salvar seu ofício da decadência em que às vezes parece estar caindo” (2013:197).

Devemos lembrar, nesse momento em que caminhamos para o final dessa argumentação, que aquele jornalismo dos primeiros anos do século $\mathrm{XX}$ foi buscar 
na observação das ruas as respostas para as mudanças que se davam em ritmo acelerado. Movimentando-se pela cidade, os repórteres de então foram capazes de atenuar fronteiras sociais e intelectuais da cidade estabelecendo um léxico comum entre os citadinos. As imaginações construídas sobre o Rio de Janeiro estavam marcadas pelo lugar de onde se originavam, as ruas. Essa imagem na qual se reconheciam os cariocas na passagem do século XIX para o XX, não funciona no momento presente. Não há uma nova imagem da cidade do Rio de Janeiro e não se imagina de onde ela possa vir. A cidade precisa de intérpretes, precisa de leitores, a cidade precisa ser melhor compreendida. Evidente que essa tarefa não é exclusiva da imprensa ou dos repórteres. Mas se esses intelectuais - que no século passado reivindicaram a primazia da interpretação da cidade moderna - tomarem para si ao menos a missão de voltar-se novamente para as ruas a fim de captar a sociabilidade dos citadinos, talvez se possa, como Vargas Llosa afirmou sobre a literatura, salvar esse ofício da decadência em que muitas vezes parece ter caído. 
4.

\section{Referências bibliográficas}

ANDRADE, Joaquim M.F.; LOGATTO, Rosângela. Imagens da seca de 1877-78 no Ceará: uma contribuição para o conhecimento das origens do fotojornalismo na imprensa brasileira. Anais da Biblioteca Nacional, v. 114, p. 71-83, 1994.

BARRETO, Lima. Os Bruzundangas. São Paulo: Editora Brasiliense, 1956. p. 107.

BECKER, Howard. Conferência A Escola de Chicago. MANA 2(2):177-188, 1996.

BOURDIEU, Pierre. O campo político. Rev. Bras. Ciênc. Polít. № 5, Brasília. Jan./Jul 2011.

Sobre a televisão - seguido de: A influência do jornalismo, e,

Os Jogos Olímpicos. Tradução Maria Lucia Machado. Rio de Janeiro: Jorge Zahar Ed., 1997.

BURGOS, Marcelo. Cidade, Territórios e Cidadania. DADOS - Revista de Ciências Sociais, Rio de Janeiro, Vol. 48, no 1, 2005, pp. 189 a 222.

CARVALHO, José Murilo de. Cidadania no Brasil: o longo caminho. $18^{a}$ edição. Rio de Janeiro: Civilização Brasileira, 2014.

Prefácio à sétima edição. In: NUNES, Victor.

Coronelismo, enxada e voto: o município e regime representativo no Brasil. $7^{\text {a }}$ edição. São Paulo: Companhia das Letras, 2012.

A construção da ordem: a elite política imperial.

Rio de Janeiro: Editora Campus, 1980.

CARVALHO, Maria Alice Rezende de. Cidade mutante. In. Redemocratização e mudança social no Brasil. Org. Maria Celina D’Araújo. Rio de Janeiro: FGV, 2014. pp. 145-160.

São Paulo: Globo, 2012.

Irineu Marinho: imprensa e cidade.

. Violência no Rio: discursos semânticos

e institucionais sobre os discursos sobre o mal. Comunicação e Política, Rio de Janeiro, ano 1, vol. 1, n. 2, 1995a. Nova Série.

Cidade escassa e violência urbana.

Série Estudos, Iuperj: Rio de Janeiro, nº 91 / agosto de 1995b. 
Quatro vezes cidade. Rio de Janeiro:

Sette Letras, 1985.

CHAMPAGNE, Patrick. A visão Mediática. In: Pierre Bourdieu (org.). A miséria do mundo. Petrópolis, RJ: Vozes, 1997.

CLIFFORD, James. A experiência etnográfica: antropologia e literatura no século XX. Org. Reginaldo Santos Gonçalves. Rio de Janeiro: Editora UFRJ, 1998.

CUNHA, Euclides da. Caderneta de campo / Euclides da Cunha. Introdução, notas e comentário: Olímpio de Souza Andrade. Rio de Janeiro: Fundação Biblioteca Nacional, 2009.

Brasileira S.A., 1967.

À margem da história. Porto, Portugal: Ed. Lello

Canudos (diário de uma expedição). Introdução de Gilberto Freyre. Rio de Janeiro: José Olympio, 1939.

DARNTON, Robert. O Grande Massacre de Gatos: e outros episódios da história cultural francesa. São Paulo: Graal, 2011.

Boemia Literária e Revolução. São Paulo: Companhia das

Letras, 1987.

FERNANDES, Florestan. A integração do negro na sociedade de classes: ensaio de interpretação sociológica. Volume I. São Paulo: Globo, 2008.

- A revolução burguesa no Brasil: ensaio de interpretação sociológica. São Paulo: Globo, 2005.

FREYRE, Gilberto. Sobrados e mucambos: decadência do patriarcado rural e desenvolvimento do urbano. Rio de Janeiro: José Olympio, 1985.

GALVÃO, Walnice Nogueira. No calor da hora. São Paulo: Ática, 1994.

GEERTZ, Clifford. Obras e vidas: o antropólogo como autor. Rio de Janeiro: Ed. UFRJ, 2005.

GIRARDI JR, Liráucio. A reportagem como experiência etnográfica. Anuário de Jornalismo, v. 2, p. 199-212, 2000.

GLOCK, Clarinha. Mapa de riscos para jornalistas. Miami: Colonial Press International Inc, 2006.

HOHLFELDT, Antonio Carlos. O repórter Euclides da Cunha em Canudos. Estudos em Jornalismo e Mídia - Ano VI, n. 2 p.131-147, jul./dez. 2009 
HOLLOWAY. Thomas. Polícia no Rio de Janeiro: repressão e resistência em uma cidade do século XIX. Tradução de Francisco de Castro Azevedo. Rio de Janeiro: FGV, 1997.

LEPENIES, Wolf. As Três Culturas. Vol. 13. Edusp, 1996.

MACEDO, Joaquim Manuel de. Memórias da Rua do Ouvidor. Rio de Janeiro: Typographia Perseverança, 1878.

MALINOWSKI, Bronislaw. Um diário no sentido estrito do termo. Rio de Janeiro: Record. 1997.

MAUAD, Ana Maria. $O$ olho da história: análise da imagem fotográfica na construção de uma memória sobre o conflito de Canudos. Acervo- Revista do Arquivo Nacional, Rio de Janeiro, v. 6, n. 1-2, p. 25-40, jan/dez 1993.

MOLICA, Fernando (Org.). 50 anos de crimes - Reportagens policiais que marcaram o jornalismo brasileiro. Rio de Janeiro: Editora Record, 2007.

NOBRE, Carlos. Direto do front: a cobertura jornalística de ações policiais em favelas do Rio de Janeiro. ALCEU, Rio de Janeiro, n 11, Rio de Janeiro: Editora PUC, 2005. p. 104-119.

NOVAIS, Fernando. Entrevista Fernando Novais. In: PRADO JÚNIOR, Caio. Formação do Brasil contemporâneo:Colônia. São Paulo: Companhia das Letras, 2011.

NUNES, Victor. Coronelismo, enxada e voto: o município e regime representativo no Brasil. Rio de Janeiro: Nova Fronteira, 1997.

O’DONNELL, Julia Galli. No olho da rua: a etnografia urbana de João do Rio. Rio de Janeiro: UFRJ/ Museu Nacional, 2007.

PAIVA, Anabela; RAMOS, Silvia. Mídia e Violência: tendências na cobertura de criminalidade e segurança no Brasil. Rio de Janeiro: IUPERJ, 2007.

PRADO JÚNIOR, Caio. Formação do Brasil contemporâneo: Colônia. São Paulo: Companhia das Letras, 2011.

RAMA, Angel. A cidade das letras. Editora Boitempo, 2015.

RIBEIRO, Darcy. O Povo Brasileiro: A formação e o sentido de Brasil. $2^{\mathrm{a}}$ ed. São Paulo: Companhia das Letras, 1995.

RIO, João do. A alma encantadora das ruas: crônicas / João do Rio. $2^{\text {a }}$ edição. São Paulo: Martin Claret, 2013.

RONDELLI, Elizabeth. Imagens da violência e práticas discursivas. RONDELLI et alli (orgs). Linguagens da violência. Rio de Janeiro: Rocco, 2000, p. 144-162. 
SEVCENKO, Nicolau. Literatura como missão: tensões sociais e criação cultural na Primeira República. São Paulo: Editora Brasiliense, 1983.

SILVA, Helio R.S. A situação etnográfica: andar e ver. Horizontes Antropológicos/ UFRGS. IFCH, PPGAS, Porto Alegre: PPGAS, Ano 15, n.32. p.171-188, 2009.

SIMMEL, Georg. As grandes cidades e a vida do espírito (1903). Mana 11.2, 2005: 577-591.

. O dinheiro na cultura moderna (1896). In. SOUZA, Jessé e

ÖELZE, Berthold. Simmel e a modernidade. Brasília: UnB, 1998. Pgs. 23-40.

SONTAG, Susan. Diante da dor dos outros. Tradução Rubens Figueiredo. São Paulo: Companhia das Letras, 2003.

TOCQUEVILLE, Alexis de. O Antigo Regime e a Revolução. Org. J. P. Mayer; trad. Rosemary Costhek Abílio. São Paulo: Editora WMF Martins Fontes, 2009. . A democracia na América. Belo Horizonte, Itatiaia;

São Paulo, Editora da Universidade de São Paulo, 597 p., 1998.

VALLADARES, Lícia do Prado. A invenção da favela - do mito de origem à favela.com. Rio de Janeiro: Editora FGV, 2005.

VALLADARES, Lícia do Prado; LIMA, Roberto Kant. A Escola de Chicago: entrevista com Isaac Joseph. BIB, Rio de Janeiro, $\mathrm{n}^{\circ} 49,1^{\circ}$ semestre de 2000 , pp. 3-13.

VARGAS LLOSA, Mario. A civilização do espetáculo: uma radiografia do nosso tempo e da nossa cultura. Tradução Ivone Benedetti. $1^{a}$ edição. Rio de Janeiro: Objetiva, 2013.

WERNECK VIANA, Luiz. A propósito de uma introdução. In. Redemocratização e mudança social no Brasil. Org. Maria Celina D’Araújo. Rio de Janeiro: FGV, 2014. pp. 11-17. 